\title{
Design, Synthesis and Pharmacological \\ Evaluation of Novel Endomorphin Analogues with \\ Multiple Structural Modifications
}

\author{
Ph.D. Thesis
}

Jayapal Reddy Mallareddy

Chemical Ph.D. School

Szeged

2012 


\title{
Design, Synthesis and Pharmacological \\ Evaluation of Novel Endomorphin Analogues with \\ Multiple Structural Modifications
}

\author{
Ph.D. Thesis
}

Jayapal Reddy Mallareddy

\author{
Supervisor \\ Dr. Géza Tóth
}

Chemical Ph.D. School

Chemical Biology Laboratory, Institute of Biochemistry, Biological

Research Centre, Hungarian Academy of Sciences

Szeged

2012 


\section{Table of contents}

List of abbreviations.......................................................................... 4

List of Figures and Tables ............................................................................ 7

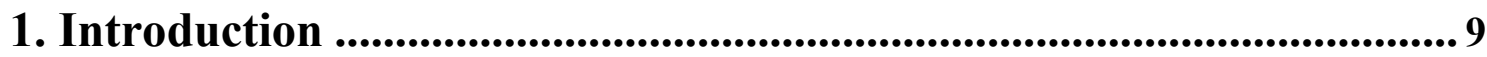

1.1. The opioid system ....................................................................................................9

1.2. Effector mechanisms ........................................................................................... 12

1.3. Development and clinical applications of opioid ligands............................. 12

1.4. Blood-brain barrier and its significance ......................................................... 13

1.5. Discovery of endomorphins............................................................................... 14

1.6. Structural modifications of endomorphins....................................................... 15

1.7. Stability of endomorphins ........................................................................... 19

1.8. Importance of chirality of alicyclic $\beta$-amino acids and isomerism in endomorphins............................................................................................... 20

1.9. Pharmacology of endomorphins ......................................................................22

1.10. Function of endomorphins ............................................................................... 23

1.11. Radioactive isotopes as tracers ....................................................................24

1.12. Tritium and tritium labeling methods of peptides.......................................25

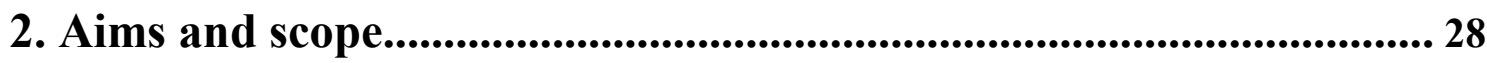

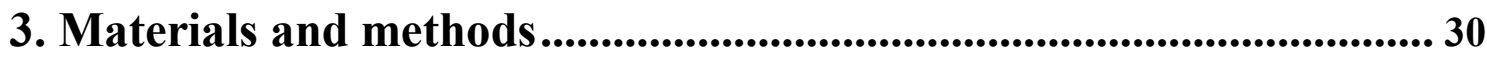

3.1. Chemicals ..........................................................................................................30

3.2. Analytical methods ...............................................................................................31

3.3. Peptide synthesis, purification and determination of configuration of the incorporated alicyclic $\beta$-Amino acids ....................................................32

3.4. Tritium labeling of peptides ................................................................................33

3.5. Animals ................................................................................................................34

3.6. Rat brain membrane preparation ..................................................................34

3.7. Radioligand-binding assay ...............................................................................35

3.8. Ligand-stimulated $\left[{ }^{35} \mathrm{~S}\right] \mathrm{GTP} \gamma \mathrm{S}$ functional binding assay ...........................36

3.9. Determination of the half-lives.........................................................................36 
3.10. BBB study of selected EM-2 analogues .................................................337

a. Determination of n-octanol/water partition coefficient ........................337

b. Measurement of the permeability of the peptides....................................3.

4. Results .............................................................................................. 39

4.1. Incorporation of unnatural amino acids into endomorphins....................39

4.2. Synthesis of novel endomorphin analogues ...................................................41

4.3. Receptor binding affinities and selectivities of new

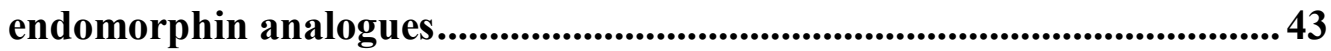

4.4. $\left[{ }^{35} \mathrm{~S}\right] \mathrm{GTP} \gamma \mathrm{S}$ functional binding assay of new endomorphin analogues .... 46

4.5. Enzymatic degradation.............................................................................49

4.6. In vitro $\mathrm{BBB}$ permeability of EM-2 analogues by brain capillary endothelial cells ..........................................................................5

4.7. In vivo characterization of most potent EM-2 analogues ............................52

4.8. Tritiated neuropeptides .......................................................................53

5. Discussion .......................................................................... 56

6. Summary of findings .................................................................... 63

7. Acknowledgements ............................................................... 65

8. References..................................................................................... 67

9. Összefoglaló ................................................................................ 83

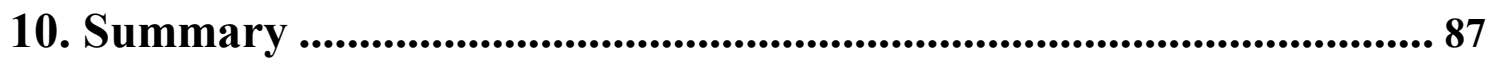

11. List of publications and posters.................................................. 91

11.1. List of thesis related publications .......................................................91

11.2. List of not related to the thesis publications ..........................................92

11.3. Manuscripts under preparation ......................................................................93

11.4. Oral presentations ...............................................................................93

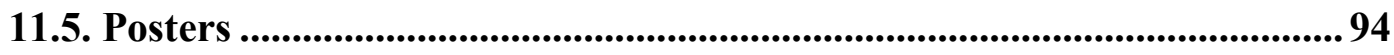




\section{List of Abbreviations}

$\Delta$ Acpc

Acpc

$\Delta$ Achc

Achc

$\mathrm{ACN}$

$\mathrm{AcOH}$

Aia

Aib

BBB

Boc

BSA

Cha

$\mathrm{Ci}$

CNS

${ }^{\circ} \mathrm{C}$

DAMGO

DCC

DCM

DIEA

DMF

DMSO

Dmt

DOR

EGTA

ESI-MS

$\mathrm{EC}_{50}$

EM-1 2-aminocyclopent-3-enecarboxylic acid

2-aminocyclopentanecarboxylic acid

2-aminocyclohex-6-enecarboxylic acid

2-aminocyclohexanecarboxylic acid

acetonitrile

acetic acid

4-amino-1,2,4,5-tetrahydro-indolo[2,3-c]-azepin-3-one

2-aminoisobutyric acid

blood-brain barrier

tert-butyloxycarbonyl

bovine serum albumin

cyclohexylalanine

curie

central nervous system

degrees centigrade

H-Tyr-D-Ala-Gly-NMePhe-Gly-ol

$\mathrm{N}, \mathrm{N}$-dicyclohexylcarbodiimide

dichloromethane

diisopropylethylamine

dimethylformamide

dimethylsulfoxide

2',6'-dimethyltyrosine

$\delta$-opioid receptor

ethylene glycol-bis(2-aminoethyl ether)- $N, N, N, N$-tetra

acetic acid

electrospray ionization mass spectrometry

half maximal effective concentration

endomrrphin-1: H-Tyr-Pro-Trp-Phe- $\mathrm{NH}_{2}$ 


\begin{tabular}{|c|c|}
\hline EM-2 & endomorphin-2: H-Tyr-Pro-Phe-Phe- $\mathrm{NH}_{2}$ \\
\hline $\mathrm{EtOH}$ & ethanol \\
\hline EBA & evans blue labeled albumin \\
\hline GITC & $2,3,4,6$-tetra-O-acetyl- $\beta$-glucopyranosyl isothiocyanate \\
\hline GDP & guanosine-5' -diphosphate \\
\hline GPCR & G-protein-coupled receptor \\
\hline GTP & guanosine-triphosphate \\
\hline GTP $\gamma \mathrm{S}$ & guanosine-5'-O-(3-thio)triphosphate \\
\hline Hfe & homophenylalanine \\
\hline $\mathrm{HOBt}$ & 1-hydroxybenzotriazole \\
\hline HPLC & high performance liquid chromatography \\
\hline HRMS & high-resolution mass spectrometry \\
\hline Hyp & $(2 S, 4 R)$-hydroxyproline \\
\hline i.c.v & intracerebroventricular \\
\hline $\mathrm{i}-\mathrm{PrOH}$ & iso-Propanol \\
\hline $\mathrm{Ile}^{5,6}$-deltorphin-2 & H-Tyr-D-Ala-Phe-Glu-Ile-Ile-Gly- $\mathrm{NH}_{2}$ \\
\hline Inp & piperidine-4-carboxylic acid \\
\hline i.t & intrathecal \\
\hline $\mathrm{K}_{\mathrm{d}}$ & equilibrium dissociation constant \\
\hline$K_{\mathrm{i}}$ & inhibitory constant \\
\hline KOR & $\kappa$-opioid receptor \\
\hline MBHA & 4-methylbenzhydrylamine \\
\hline $\mathrm{MeOH}$ & methanol \\
\hline MALDI-TOF & matrix assisted laser desorption ionization-time of flight \\
\hline MOR & $\mu$-opioid receptor \\
\hline MS & mass spectrometry \\
\hline$\Delta^{\mathrm{z}} \mathrm{Phe}$ & $(Z)-\alpha, \beta$-didehydrophenylalanine \\
\hline$\beta \mathrm{MePhe}$ & $\beta$-methylphenylalanine \\
\hline$\beta$ Pro & $\beta$-homoproline \\
\hline Nip & piperidine-3-carboxylic acid \\
\hline NMR & nuclear magnetic resonance spectroscopy \\
\hline
\end{tabular}




\begin{tabular}{|c|c|}
\hline NOE & nuclear Overhauser effect \\
\hline NVA & norvaline \\
\hline pFPhe & para-fluorophenylalanine \\
\hline PAL & peptidylamidoglycolate lyase \\
\hline PAM & peptidylglycine $\alpha$-amidating monooxygenase \\
\hline Phg & phenylglycine \\
\hline PHM & peptidylglycine- $\alpha$-hydroxylating monooxygenase \\
\hline Pip & piperidine-2-carboxylic acid \\
\hline Pra & propargylglycine \\
\hline$\Psi$ Pro & pseudoproline \\
\hline $\mathrm{R}_{\mathrm{f}}$ & retention factor \\
\hline ROESY & rotating-frame Overhauser effect spectroscopy \\
\hline RP-HPLC & reversed-phase high-performance liquid chromatography \\
\hline $\mathrm{TBq}$ & tera Becquerel \\
\hline TEA & triethylamine \\
\hline TFA & trifluoroacetic acid \\
\hline Tic & 1,2,3,4-tetrahydroisoquinoline-3-carboxylic acid \\
\hline TLC & thin-layer chromatography \\
\hline $\mathrm{TM}$ & transmembrane \\
\hline TOCSY & total correlation spectroscopy \\
\hline Tris & tris-(hydroxymethyl)-aminomethane \\
\hline Tyr-W-MIF & H-Tyr-Pro-Trp-Gly-NH 2 \\
\hline SAR & structure activity relationship \\
\hline SF & sodium fluorescein \\
\hline \multirow[t]{2}{*}{ UFP-12 } & Phe-Gly-Gly-pFPhe-Thr-Gly-Aib-Arg-Lys-Ser-Ala-Arg- \\
\hline & Lys-Arg-Lys-Asn-Gln-OH \\
\hline
\end{tabular}




\section{List of Figures and Tables}

Figure 1. Schematic chemical structures of the endomorphins

Figure 2. Amino acid derivatives used for synthesis of precursor peptides for tritiation

Figure 3A. Chemical structures of unnatural amino acids incorporated in analogues 2-8 and 10-16

Figure 3B. Chemical structures of unnatural amino acids incorporated in second position of endomorphin-2 (analogues 17-21)

Figure 4. Representative curves of competitive receptor binding of novel endomorphins analogues at $\mu$ and $\delta$-opioid receptor sites. Points represent the means \pm SEM of at least three different experiments, each performed in duplicate

Figure 5. Stimulation of G-proteins by novel endomorphin analogues in rat brain membranes. Basal activity (basal = 'total binding' - 'nonspecific binding') is taken as $100 \%$. Nonspecific binding is determined in the presence of $10 \mu \mathrm{M}$ unlabeled GTP $\gamma$ S. Points represent the means \pm SEM of at least three independent measurements, each performed in triplicate

Figure 6. The $\mathrm{P}_{\mathrm{e}}$ of peptide 1,2 and 3 was calculated and compared to the permeability of EM-2. As a control the $\mathrm{P}_{\mathrm{e}}$ of sodium fluorescein (SF) and Evans blue labeled albumin (EBA) was also calculated. Data are presented as means $\pm \mathrm{SEM}$. * = $\mathrm{P}<0.05$ as assessed by ANOVA and Bonferroni's post hoc test (compared to EM2)

Figure 7. Reaction catalyzed by bifunctional PAM. The PHM domain catalyzes the oxygen- and ascorbate-dependent hydroxylation of peptidylglycine, forming the $\alpha$-hydroxyglycine intermediate. The PAL domain cleaves the intermediate and releases amidated peptide and glyoxylate. Colored atoms indicate that molecular oxygen is incorporated into $\alpha$-hydroxyglycine, and that the product amide nitrogen is derived from the substrate glycine

Table 1. Classification of endogenous opioid peptides

Table 2. Some typical structural modifications performed on endomorphins

Table 3. Analytical properties (RP-HPLC, TLC and HMRS/ESI-MS data) of endomorphins and their derivatives 
Table 4. Summary of inhibitory constants $\left(K_{\mathrm{i}}\right)$ and selectivity of endomorphins and their analogues measured in a rat brain membrane preparation

Table 5. Summary of $\left[{ }^{35} \mathrm{~S}\right] \mathrm{GTP} \gamma \mathrm{S}$ functional assays with selected endomorphin analogues measured in a rat brain membrane preparation

Table 6. Half-lives of the endomorphins and their potent analogues in crude rat brain membrane homogenate

Table 7. Inhibitory constants $\left(K_{\mathrm{i}}\right)$, selectivities, half-life and $\log P$ values of endomorphin-2 and its analogues used in BBB studies

Table 8. Specific radioactivities of tritiated ligands 


\section{Introduction}

\subsection{The opioid system}

Pain is a highly subjective, unique sensation. Opium has been extracted from the poppy plant and used to treat pain for thousands of years but with little understanding of its mechanism of action. The major active ingredient of opium is the alkaloid morphine, which was first isolated by Wilhelm Sertürner in 1805. The discovery of morphine was considered a milestone in medical history. Despite its severe side effects like respiratory depression, severe drowsiness, weakness, dizziness, slurred speech, nausea or vomiting, physical dependence and constipation etc., it's still being used as a medicine for pain relief.

Opioid receptors were first proposed in 1954 by Beckett and Casy by demonstrating the existence of specific sites for opioid ligands, which was a breakthrough in biochemical pharmacology [1]. Opioid receptors, mediating the actions of opiate alkaloids and opioid peptides, belong to the superfamily of G-protein-coupled receptors (GPCRs). These receptors mediate a wide variety of physiological functions including neurotransmission, hormone- and enzyme release from endocrine and exocrine glands, immune responses, cardiac- and smooth-muscle contraction and blood pressure regulation [2]. To date, three types of opioid-binding sites have been identified based on pharmacological and behavioral studies, namely $\mu-(\mathrm{MOR}), \delta-(\mathrm{DOR})$, and $\kappa_{-}$(KOR) receptors. Although, only single genes for MOR, DOR and KOR have been cloned, the opioid-binding sites do not form homogenous populations [3].

Opioid receptors belong to the membrane-bound class A (Rhodopsin) family of $\mathrm{G}_{\mathrm{i}} / \mathrm{G}_{\mathrm{o}}$ protein coupled receptors composed of a single polypeptide chain with seven transmembrane (TM) domains with an extracellular N-terminal and an intracellular Cterminal domain. These receptors are about $60-70 \%$ identical to each other with the greatest homology in the TM helices, the intracellular loops, and a portion of the C- 
terminal tail adjacent to the TM7 domain and the greatest diversity in their $\mathrm{N}$ - and $\mathrm{C}$ termini as well as their extracellular loops [4]. The extracellular N-terminus of the receptor proteins have varying number of glycosylation sites, [5] the intracellular Cterminus can be modified post-translationally by fatty acids and it contains multiple phosphorylation sites. Both termini with the extracellular loops have been shown to be highly diverse in amino acid sequences [6].

Opioid receptors are widely distributed throughout the brain and periphery [7]. Higher $\mu$-receptor density has been found for the thalamus, caudate putamen, neocortex, periaqueductal gray and the dorsal horn of the spinal cord [8]. The olfactory bulb, neocortex, caudate putamen, nucleus accumbens and amygdala are rich in $\delta$-receptors. $\kappa$ receptors are observed in areas of the cerebral cortex, nucleus accumbens, claustrum and hypothalamus [7].

The exo- and endo opioid ligands regulate the nociceptive pathway that includes pain perception, modulation and the response to painful stimuli. In addition to this, opioid ligands mediate respiratory, cardiovascular, gastrointestinal, renal, and hepatic functions, mood and feeding behavior. Clinical applications of opioid ligands are impeded due to the side-effects such as the development of tolerance and dependence [7, 9, 10 and 11]. The ligands and their precursor proteins for $\mu$-, $\delta$ - and $\kappa$-receptors have been investigated thoroughly. $\beta$-Endorphin has shown equal activity at $\mu$ - and $\delta$-receptors with a much lower affinity for $\kappa$-receptors [12]. Met- and Leu- enkephalins have high affinities for $\delta$ receptors and lower affinities for $\mu$-receptors [13]. The opioid fragments of prodynorphin, particularly dynorphin A and dynorphin B, have high affinity for $\kappa$-receptors but also have significant affinity for $\mu$-and $\delta$-receptors [14]. Nociceptin/Orphanin FQ is the endogenous ligand for the $\mathrm{ORL}_{1}$-receptor; it has little affinity for the $\mu$-, $\delta$ - and $\kappa$ receptors [15, 16 and 17]. Subsequently, a large number of different opioid receptoracting peptides, peptide fragments and preproproteins have been isolated and studied from a variety of different species and natural sources. The classification of the endogenous opioid ligands is shown in Table 1. 


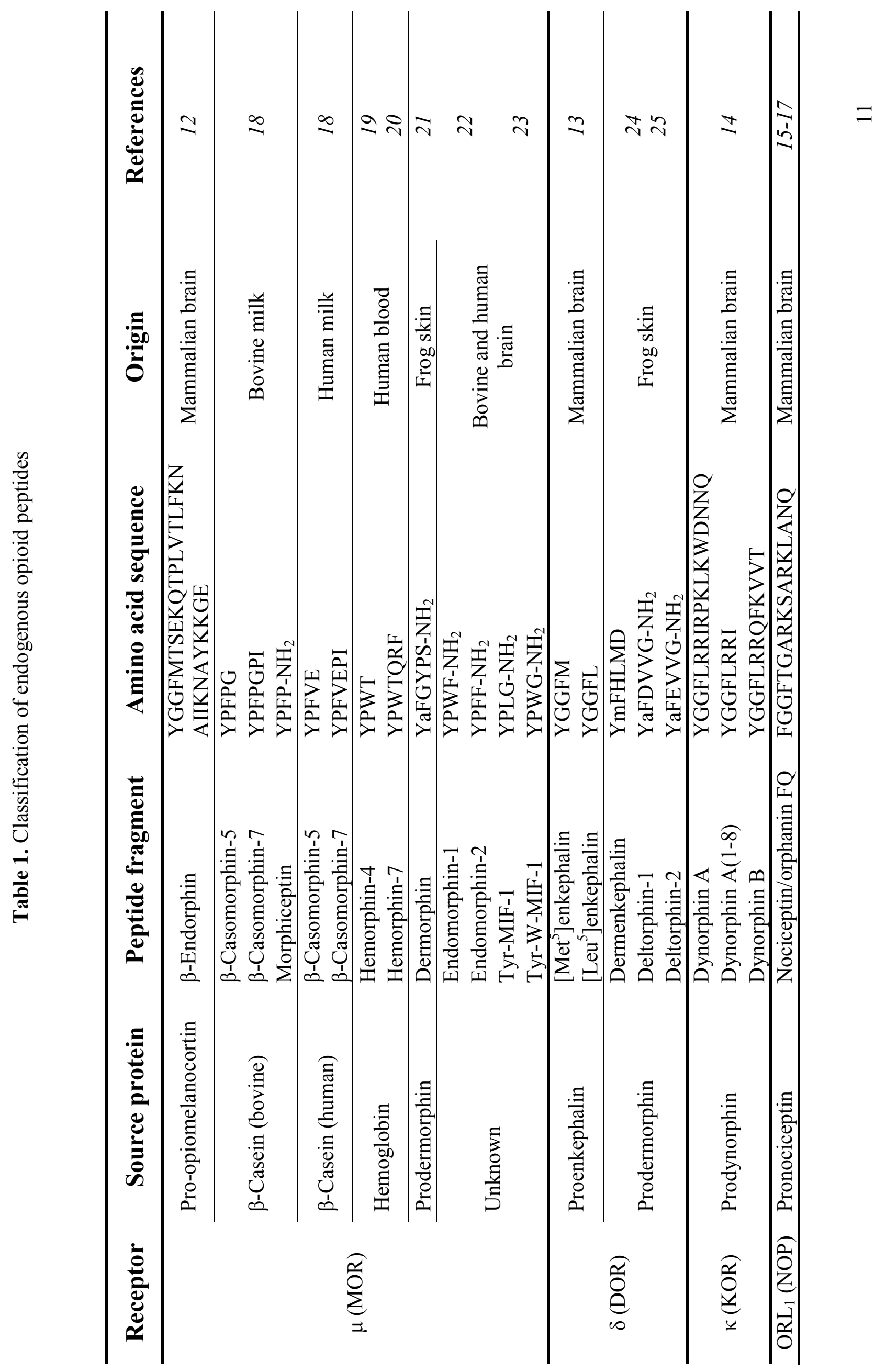




\subsection{Effector mechanisms}

When an agonist ligand (morphine, enkephalin, N/OFQ etc) binds to the receptor, it induces a conformational change in the receptor, consequently receptor proteins become activated with the exchange of guanine nucleotides in the $G_{\alpha}$-subunit. Upon activation, it relays the signal to other components in the downstream signaling cascade. Activation of the $\mathrm{G}_{\alpha}$ subunit of regulatory G-proteins $\left(\mathrm{G}_{\mathrm{i}} / \mathrm{G}_{\mathrm{q}}\right.$ and $\mathrm{G}_{\mathrm{o}}$ types mainly) is the key factor in opioid signaling within the membrane $[11,18]$. Initially, it was thought that $\mu$ - and $\delta$-receptors coupled through $\mathrm{G}_{\mathrm{i}} / \mathrm{G}_{\mathrm{o}}$ proteins activate an inwardly rectifying potassium channel and inhibit voltage-operated calcium channels whereas $\kappa$-receptors only inhibit voltage-operated calcium channels. Later it was shown, that all of the opioid receptors most likely share common effector mechanisms [19, 20]. Activation of any type of opioid receptor inhibits adenylate cyclase, resulting in a fall in intracellular cAMP and diminished action potential firing. This causes a reduced flow of nociceptive information to the brain [11]. Conversely, opioid addicts undergoing withdrawal suffer elevated cAMP levels and enhanced protein kinase A activity, resulting in an increased neurotransmitter release [26].

\subsection{Development and clinical applications of opioid ligands}

Opioid receptors are unique in that their existence was proposed before the discovery of the natural agonists [1]. Opioid alkaloids morphine, codeine and thebaine were considered as "natural-product hits" on which chemical programmes were based to design analogues with an improved pharmacology. Since morphine administration is associated with undesirable side effects, great scientific attention is directed towards the design of modified opioid peptides which maintain an ability to bind to $\mu$-opioid receptors with high affinity and selectivity and good penetration through the blood-brainbarrier (BBB). The discovery of the enkephalins of the $\delta$-receptor, evoked the idea to synthesize a new class of opioid agonists with a lack of addictive properties of morphine. [27]. Such synthetic products are being tested in animal models, and the development of 
a selective non-peptide agonist is under consideration by a number of commercial drug houses. Preclinical studies suggest that $\delta$-agonists may have a superior profile as analgesics, but this will only be established when such an agent is successfully introduced into clinical investigation; other possible applications of selective ligands for this receptor may emerge from clinical experience. The development of opioid ligands for $\kappa$-opioid receptor analgesics was based on the preclinical pharmacology of the 6,7benzomorphans such as ketazocine and its derivatives. Although these products elicited powerful antinociceptive effect, they are not a substitute for morphine. The clinical utilities of agonists or antagonists for the $\mathrm{ORL}_{1}$ receptor can only be the subject of speculation. [28].

\subsection{Blood-Brain Barrier (BBB) and its significance}

The BBB is an active interface between the circulation and the central nervous system (CNS) which confines the free movement of different substances between the two compartments and plays a crucial role in the maintenance of the homeostasis of the CNS. The BBB has a dual role, a barrier and a carrier function. The barrier function restricts the transport from the blood to the brain of potentially toxic or harmful substances; the carrier function is responsible for the transport of nutrients to the brain and removal of metabolites. The relative impermeability of the barrier not only protects the brain from potentially harmful substances, but also prevents different drugs to reach therapeutically relevant concentrations in the brain [29]. The BBB has a significant importance in the clinical practice as well. On one side there are a large number of neurological disorders including cerebral ischemia, brain trauma and tumors, neurodegenerative disorders, in which the permeability of the BBB is increased. On the other hand due to the relative impermeability of the barrier many drugs are unable to reach the CNS in therapeutically relevant concentration, making the $\mathrm{BBB}$ one of the major hindrances in the treatment of CNS disorders [30]. Most of the native opioid peptides in general have a limited in vivo efficacy, due to their poor metabolic stability and limited delivery to the CNS [31]. 
Therefore it is of great importance to design opioid peptide analogues with improved peptidase resistance and greater BBB permeation.

\subsection{Discovery of endomorphins}

In 1997, J .E. Zadina and coworkers synthesized a number of Tyr-W-MIF (H-TyrPro-Trp-Gly- $\mathrm{NH}_{2}$ ) with substitution of possible natural amino acids in position 4 by using combinatorial chemistry and subsequently screened for their $\mu$-opioid receptor binding Two ligands were found with high affinity and selectivity toward the $\mu$-opioid receptor. These tetrapeptides were isolated initially from bovine brain [22], and subsequently from human brain cortex [32] and were named endomorphin-1 (EM-1, HTyr-Pro-Trp-Phe-NH${ }_{2}$ ) and endomorphin-2 (EM-2, H-Tyr-Pro-Phe-Phe- $\mathrm{NH}_{2}$ ). Schematic chemical structures of endomorphins are shown in Figure 1. Endomorphins were the first peptides isolated from brain that bind to the $\mu$-opioid receptor with high affinity and selectivity and therefore were proposed as endogenous $\mu$-opioid receptor ligands [22]. Their precursor(s) or the possible biosynthetic route(s) still remains unidentified, whereas the biosynthetic pathways for other vertebrate opioid peptides have already been clarified [33]. Concerning their anatomical distribution, EM-1 is widely and densely distributed throughout the brain and upper brainstem and is particularly abundant in the nucleus accumbens, the cortex, the amygdala, the thalamus, the hypothalamus, the striatum, and the dorsal root ganglia $[34,35]$. Endomorphin-2 is more prevalent in the spinal cord and lower brainstem and in the dorsal horn of the spinal cord [34, 36 and 37]. Endomorphins display notable binding affinities $\left(K_{\mathrm{i}}=0.3\right.$ to $\left.1.5 \mathrm{nM}\right)$ and selectivities for the $\mu$-opioid receptor $\left(K_{\mathrm{i}}^{\mathrm{\mu}} / K_{\mathrm{i}}^{\delta}, K_{\mathrm{i}}^{\mathrm{K}}=4,000\right.$ and 15,000$)$ in the guinea pig ileum assay and tail-flick tests, and also interesting pharmacological and structural features. In in vivo experiments endomorphins turned out to be as effective as the majority of opioid peptides targeting the $\mu$-opioid receptors, even in low doses exhibited outstanding potencies toward both intractable acute and chronic neuropathic pain. Intracerebroventricular (i.c.v) and intrathecal (i.t) administration of endomorphins evoked sustained antinociception in wild type adult rodents in tail-flick, paw-withdrawal and tail-pressure tests [22, 38, 39, 40, 41, 
42, 43, 44 and 45]. Endomorphins and morphine are alike in binding to the $\mu$-opioid receptor, but endomorphins are thought to inhibit pain with fewer side effects [46].<smiles>NC(=O)C(Cc1ccccc1)NC(=O)C(Cc1c[nH]c2ccccc12)NC(=O)C1CCCN1C(=O)C(N)Cc1ccc(O)cc1</smiles>

Endomorphin-1

(H-Tyr-Pro-Trp-Phe-NH ${ }_{2}$ )<smiles>NC(=O)C(Cc1ccccc1)NC(=O)C(Cc1ccccc1)NC(=O)C1CCCN1C(=O)C(N)Cc1ccc(O)cc1</smiles>

Endomorphin-2

(H-Tyr-Pro-Phe-Phe- $\mathrm{NH}_{2}$ )

Figure 1. Schematic chemical structures of the endomorphins

\subsection{Structural modifications of endomorphins}

For the classic endogenous opioid peptides, like enkephalins, dynorphins, endorphins the N-terminal Tyr-Gly-Gly-Phe sequence confers the "message sequence", while the remaining C-terminal constitutes the "address sequence" [47]. It was initially thought that in endomorphins the "message sequence" consists of two pharmacophore amino acids, the $\operatorname{Tyr}^{1}$ and $\operatorname{Trp}^{3} / \mathrm{Phe}^{3}$ residues which are essential for the $\mu$-opioid receptor recognition and binding, while the "address sequence" is found to be responsible for $\mu$ opioid receptor vs $\delta$-opioid receptor selectivity [48]. Later it was found that not the whole "message sequence" but the phenolic group of $\mathrm{Tyr}^{1}$ and the aromatic side chain at position 3 are essential for the binding of endomorphins to $\mu$-opioid receptors. In the "address sequence" the C-terminal aromatic side chain and amine functions have been found to be responsible for $\mu$-vs $\delta$-opioid receptor selectivity of endomorphins [49]. 
Hence endomorphins bind to the $\mu$-opioid receptor with high affinity they have drawn substantial attention from a pharmacological aspect. Upon exogenous application, endomorphins suffer from serious limitations including short duration of action, lack of activity after oral administration, relative inability to cross the BBB into the central nervous system (CNS) and poor metabolic stability [31, 50 and 51]. To overcome aforementioned difficulties/restrictions, a systematic modification of the peptide sequence is required.

The substitution of Tyr $^{1}$ with Dmt resulted in an increased affinity not only for the $\mu$-, but also for the $\delta$-receptors [52, 53, 54 and 55]. Furthermore, incorporation of N-allyl$\mathrm{Dmt}^{1}$ in EM-1 and -2 resulted in neutral $\mu$-opioid antagonists, these analogues inhibited the naloxone/naltrexone-elicited withdrawal syndromes without adverse effects observed with inverse agonist alkaloid-derived compounds [56, 57]. But, the substitution of N, Nallyl-Dmt ${ }^{1}$ yielded a decreased $\mu$-opioid receptor affinity which suggests that the presence and the conformation of $\mathrm{Tyr}^{1}$ is crucial for interaction with opioid receptors.

Proline in the second position of endomorphins is considered a spacer residue, connecting two pharmacophoric aromatic residues, $\operatorname{Tyr}^{1}$ and $\operatorname{Trp}^{3} / \mathrm{Phe}^{3}$ [47]. Incorporation of $\mathrm{Acpc} / \mathrm{Achc}$ residues into the place of $\mathrm{Pro}^{2}$ in endomorphins yielded analogues with increased proteolytic stability and binding ability depending on the configuration of the incorporated alicyclic $\beta$-amino acid $[58,59]$. Replacement of Pro ${ }^{2}$ with Tic (1,2,3,4-tetrahydroisoquinoline-3-carboxylic acid) in endomorphins resulted in dual properties, acting as a $\mu$-receptor agonist $/ \delta$-antagonist. This is remarkable because mixed $\mu$-agonist $/ \delta$-antagonist ligands are assumed to have a higher tendency to suppress the development of analgesic tolerance [60]. Furthermore, insertion of pseudoproline ( $\Psi$ Pro) in place of $\mathrm{Pro}^{2}$ in EM-2 analogues, retained $\mu$-opioid receptor affinity and selectivity [61]. Additionally, six-membered heterocyclic rings, such as piperidine-2-, 3and 4-carboxylic acids [(S)-Pip, $(R)$-Nip and Inp, respectively] were also incorporated into the place of Pro $^{2}$ in EM-2. $\left[(R)-\mathrm{Nip}^{2}\right] \mathrm{EM}-2$ displayed higher proteolytic stability and increased affinity for the $\mu$-opioid receptor compared to the parent peptide in rat brain 
homogenate [62]. These results confirm that Pro $^{2}$ targeting modifications yield proteolytically stable analogues.

Substitution of $\mathrm{Phe}^{3}$ with cyclohexylalanine (Cha) residue, which lacks aromaticity and a quadrupole moment, led to decreased affinities relative to EM-2, suggesting that the presence of $\pi$ electrons or the planarity of the aromatic ring is necessary for the ligand-receptor interaction [63]. Incorporation of the $\operatorname{Trp}^{3} / \mathrm{Phe}^{3}$ residues of the endomorphins with $\beta$-(1-naphthyl)alanine (1Nal), $\beta$-(2-naphthyl)alanine (2Nal), 4chlorophenylalanine (pClPhe), 3,4-dichlorophenylalanine $\left(\mathrm{Cl}_{2} \mathrm{Phe}\right)$, homophenylalanine (Hfe) or Phenylglycine (Phg) resulted in analogues with decreased binding potencies [6365]. Observations of these results suggest that in addition to the presence of an aromatic ring at position 3, the steric situation of the side chain determines the outcome of the receptor-ligand interaction.

The insertion of $\mathrm{pFPhe}^{4}$ instead of $\mathrm{Phe}^{4}$ in enkephalin yielded increased potency in functional assays [66]. Similar results were observed in endomorphins as well [67]. Tömböly and co-workers observed remarkable differences in biochemical properties of the $\beta \mathrm{MePhe}$ substituted endomorphins with different stereochemistry in the position of $\mathrm{Phe}^{4}$ in EM-1 and $\mathrm{Phe}^{3} / \mathrm{Phe}^{4}$ in EM-2. Substitution of $\beta \mathrm{MePhe}^{4}$ resulted in increased affinity and potency in EM-1 and -2 , but the substitution of Phe ${ }^{3}$ by $\beta$ MePhe in EM-2 resulted in a loss of $\mu$-opioid receptor affinity which confirmed that the proper orientation of $\mathrm{Phe}^{4}$ aromatic side chain is a crucial part of the address sequence for $\mu$-opioid receptor activity [68]. Chemical modification of the C-terminal part of the endomorphins, including replacement of the carboxamide group by hydroxymethyl $\left(\mathrm{CH}_{2}-\mathrm{OH}\right)$, methylester $(\mathrm{COOMe})$ or hydrazide $\left(\mathrm{CO}-\mathrm{NHNH}_{2}\right)$ led to similarly potent analogues compared to the parent ligands [69]. The above detailed structural modifications are summarized in Table 2. 
Table 2. Some typical structural modifications performed on endomorphins

\begin{tabular}{|c|c|c|c|}
\hline Amino acids & $\begin{array}{l}\text { Inserted } \\
\text { position in } \\
\text { the } \\
\text { sequence }\end{array}$ & $\begin{array}{l}\text { Effects of substitution on } \\
\text { endomorphins }\end{array}$ & References \\
\hline 2,6-dimethyltyrosine (Dmt) & $\operatorname{Tyr}^{1}$ & $\begin{array}{l}\text { Increased binding potency } \\
\text { and decreased receptor } \\
\text { selectivity }\end{array}$ & $52-55$ \\
\hline $\begin{array}{l}\mathrm{N} \text {-allylation of the } \mathrm{N} \text {-terminal 2,6- } \\
\text { dimethyltyrosine (N-allyl-Dmt) }\end{array}$ & $\operatorname{Tyr}^{1}$ & $\begin{array}{l}\text { Decreased } \mu \text {-opioid receptor } \\
\text { affinity }\end{array}$ & $56-57$ \\
\hline $\begin{array}{l}\text { 2-Aminocyclopentanecarboxylic } \\
\text { acid (Acpc), } \\
\text { 2-Aminocyclohexanecarboxylic } \\
\text { acid (Achc) }\end{array}$ & $\mathrm{Pro}^{2}$ & $\begin{array}{l}\text { Increased, decreased or } \\
\text { unaltered receptor affinity } \\
\text { with decreased } \mu \text {-opioid } \\
\text { receptor selectivity } \\
\text { depending on chirality of } \\
\text { alicyclic } \beta \text {-amino acid }\end{array}$ & 58,59 \\
\hline $\begin{array}{l}\text { 1,2,3,4-Tetrahydroisoquinoline-3- } \\
\text { carboxylic acid (Tic) }\end{array}$ & $\mathrm{Pro}^{2}$ & $\begin{array}{l}\text { Dual properties, acting as a } \mu \text { - } \\
\text { receptor agonist } / \delta \text {-antagonist }\end{array}$ & 60 \\
\hline $\begin{array}{l}\text { Piperidine-2- carboxylic acid (Pip) } \\
\text { Piperidine-3- carboxylic acid (Nip) } \\
\text { Piperidine-4- carboxylic acid (Inp) }\end{array}$ & Pro $^{2}$ & $\begin{array}{l}\text { Nip substitution resulted in } \\
\text { the most potent analogues }\end{array}$ & 62 \\
\hline $\begin{array}{l}\text { Cyclohexylalanine }(\mathrm{Cha}) \\
\beta-(1-n a p h t y l) \text { alanine }(1 \mathrm{NaI}) \\
\beta-(2-\text {-naphtyl)alanine }(2 \mathrm{NaI}) \\
\text { 4-chlorophenylalanine }(\mathrm{pClPhe}) \\
\text { 3,4-dichlorophenylalanine }\left(\mathrm{Cl}_{2} \mathrm{Phe}\right) \\
\text { Homophenylalanine }(\mathrm{Hfe}) \\
\text { Phenylglicine }(\mathrm{Phg})\end{array}$ & $\operatorname{Trp}^{3} / \mathrm{Phe}^{3}$ & Decreased binding potency & $63,65,70$ \\
\hline $\begin{array}{l}\text { para-fluoro phenylalanine (pFPhe) } \\
\beta \text {-methylphenylalanine ( } \beta \text { MePhe) }\end{array}$ & $\mathrm{Phe}^{4}$ & $\begin{array}{l}\text { Increased potencies and } \\
\text { efficacies }\end{array}$ & 66,68 \\
\hline $\begin{array}{l}\text { Phenylalanine with carboxamide, } \\
\text { hydroxymethyl, methylester, } \\
\text { hydrazide }\end{array}$ & $\mathrm{Phe}^{4}$ & $\begin{array}{c}\text { Similar potency to the parent } \\
\text { ligands }\end{array}$ & 69 \\
\hline
\end{tabular}




\subsection{Stability of endomorphins}

Opioid peptides easily undergo rapid enzymatic degradation soon after their production. Most of the peptide-degrading enzymes are membrane-bound exo- and endopeptidases, which have active sites facing to the extracellular space. Hence the majority of degradation processes of opioid peptides take place in the extracellular space. However, an intracellular cleavage of opioid peptides after internalization by cytosolic peptidases cannot be excluded [71]. Peptide-degrading enzymes are able to split off the backbones of the endomorphins. Among the known mammalian opioid peptides, endomorphins have the longest half-lives (4-6 $\mathrm{min}$ ) due to the presence of the proline residue in the second position, which not only influences the conformation of the peptide but also confers the stability against most proteases [31, 72 and 73]. The metabolic pathway of endomorphins has been mapped and summarized in a recent review [71]. In vitro metabolic studies demonstrated that the main cleavage occurs at $\operatorname{Pro}^{2}-\operatorname{Trp}^{3}$ and $\mathrm{Pro}^{2}$ $\mathrm{Phe}^{3}$ peptide bonds; the dipeptides thus formed are then hydrolyzed into individual amino acids. Two enzymes in particular are responsible for initiating degradation of endomorphins. Dipeptidyl peptidase IV, a membrane bound serine protease and carboxypeptidase Y (producing the carboxy end), activate the process and aminopeptidases terminate the reaction [51, 74, 75 and 76]. The total degradation takes approximately $1 \mathrm{~h}$ for EM-1 and 2-3 hours for EM-2 [73, 76]. However, it has also been reported that EM-1 might be more resistant to proteolytic degradation, as it produced a longer duration of spinal antinociception compared to EM-2. The effects of protease inhibitors on degradation of endomorphins clearly indicated the role of inhibitors such as actinonin, diprotin A and Ala-pyrrolidonyl-2-nitrile in delaying or modifying the peptide potency by blocking endomorphin metabolism either in vivo or in vitro [74]. The activity of endomorphin degradation products has been examined. The obtained results revealed that the metabolic products are pharmacologically inactive; subsequently the analgesic activity is expected to be diminished within minutes of endomorphin degradation [77]. 


\subsection{Importance of chirality of alicyclic $\beta$-amino acids and isomerism in endomorphins}

Due to their unique structural properties, alicyclic $\beta$-amino acids have a significance importance in constructing biologically active substances [78]. In these amino acids, the amino and carboxyl functions are located on neighboring atoms. The two chiral centers offer four possible stereoisomers, two configurational cis- $(R, R$ and $R, S)$ and two configurational trans- $(S, S$ and $S, R)$. Incorporation of these racemic mixtures into bioactive peptides allows for diastereomers. (Diastereomers are stereoisomers that are not mirror images of one another and are non superimposable on one another). The stereo- and regio-isomers, together with the possible ring size expansions and further substitutions, significantly extend the structural diversity of alicyclic $\beta$-amino acids [78]. The insertion of an alicyclic $\beta$-amino acid in place of Pro $^{2}$ yields peptides with increased proteolytic stability while retaining or enhancing the biological activity depending on the chirality of amino acid $[58,79]$.

Hence endomorphins contain Pro in position 2, they exist as an equilibrium mixture of cis- and trans-conformations [48] and the isomerization around the $\mathrm{Tyr}^{1}-\mathrm{Pro}^{2}$ peptide bond has been reported by means of various different techniques [48, 49,80, 81, 82 and 83]. Due to the sufficient low energy ( $2-4 \mathrm{kcal} / \mathrm{mol})$ difference between the conformers allows the formation of either cis- or trans-conformers with respective population rates $[48,49]$. The ${ }^{1} \mathrm{H}-\mathrm{NMR}$ spectroscopic data and SAR studies measured in DMSO, water and SDS micelles indicated that the cis/trans ratio was 1:3 and 1:2 for EM1 and -2 , respectively [48, 81 and 83]. This balance of configurations has been shown to be alerted by incorporation of Dmt and pseudoproline ( $\psi$ Pro) in positions 1 and 2, respectively $[53,61]$.

Numerous experiments have been carried out in search of bioactive conformations of endomorphins, but none provided emphatically convincing models for the biologically relevant conformations of peptides. Depending on the experimental conditions the ratio of the two conformers varied, as they easily changed from one 
conformer to another, yielding a series of conflicting results. Furthermore, these short tetrapeptides can adopt compact or extended structures in either cis- or transconformation and this further elicits the number of possible 3D-structures [49, 81]. Consequently, the bioactive conformations of endomorphins remained an unanswered question. However, a slightly bent backbone structure was proposed for receptor-bound ligands, more recently four structural parameters were confirmed for high $\mu$-opioid activity. Those include (1) trans-conformation of N-terminal aromatic side chain, (2) the preference for gauche- conformation of aromatic side chain in the third position, (3) flexibility of the C-terminal aromatic moiety and (4) bent backbone structure of the peptide $[84,85]$.

\section{Brief description of $R \& S$ notation}

$R$ - and $S$ - notation use the Cahn-Ingold-Prelog (CIP) priority rules [86] for the assignment of the absolute configuration around a stereocenter.

Using CIP rules assign the priorities of the each bonded molecule surrounding the stereocenter. A clockwise direction is an $R$ (latin: rectus) configuration. A counterclockwise direction is an $S$ (latin: sinister) configuration.

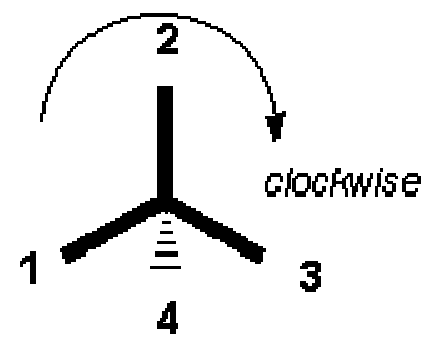

$\boldsymbol{R}$ configuration

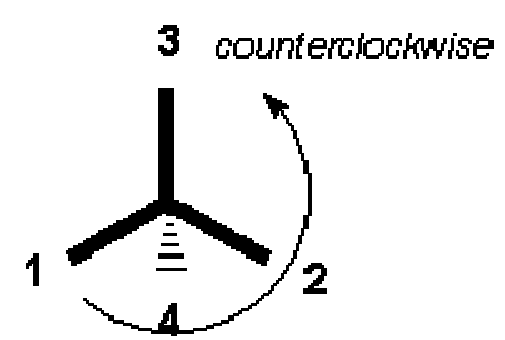

$S$ configuration

Direction of the travel 1-2-3 dictates configuration.

If least priority group present at dark position then stereochemistry reverse. 


\subsection{Pharmacology of endomorphins}

The potent antinociceptive behavior of endomorphins after i.c.v or i.t injection is blocked by $\mu$-opioid antagonists and is diminished in $\mu$-opioid receptor knockout mice. The results suggest that endormorphins preferentially bind to $\mu$-opioid binding sites [9, 22, 87 and 88]. Both peptides present similar affinities, but greater selectivities than the $\mu$-opioid full agonist DAMGO or morphine. Neither of the compounds had significant affinity for $\delta$ - or $\kappa$-opioid receptors [9]. In competitive radioligand receptor binding assays, endomorphins displace the general antagonist naloxone, DAMGO and other $\mu$ opioid selective ligands in a concentration dependent manner [9]. It has been suggested that endomorphins exert their pharmacological activities by stimulating two diverse subtypes of hypothetical $\mu$-opioid receptors, $\mu_{1}$ and $\mu_{2}$. Subcutaneous application of the $\mu_{1}$-receptor-selective antagonist naloxonazine prevents the antinociceptive and antitransit action of EM-1. Moreover these effects are partially blocked by i.c.v. naloxone or by i.p. naloxone methiodide. The $\delta$-opioid receptor antagonist naltrindole and the $\kappa$-opioid receptor antagonist nor-binaltorphimine had no effect on the antinociceptive action of EM-1 [89]. In addition to this, $\mu_{1}$-opioid receptor antagonist naloxonazine inhibits the antinociception induced by i.c.v administration of EM-2 more effectively than that of EM-1, whereas $\beta$-funaltrexamine inhibits both. These results suggest that antinociception induced by EM-1 is mediated by $\mu_{2}$-opioid receptor, whereas EM-2 preferentially acts via $\mu_{1}$-opioid receptor [42]. The $\mu_{1}$-receptor mediates supraspinal analgesia, while $\mu_{2}$ receptor associates with spinal analgesia and respiratory depression. Nevertheless, $\mu$ opioid receptor subtype genes are not identified yet. To date, it has been proposed that the receptor subtypes found are a result of oligomerization of the opioid receptors or unique opioid receptors, which might have undergone discrete post-translational modifications [88, 90]. 


\subsection{Function of endomorphins}

Endomorphins have been postulated to represent the primary endogenous ligands for the $\mu$-receptor [91]. They are considered to be partial agonists of $\mu$-opioid receptors which are coupled to the superfamily of GPCR [46]. The G-proteins are heterotrimeric proteins consisting of $\mathrm{G}_{\alpha}, \mathrm{G}_{\beta}, \mathrm{G}_{\gamma}$ subunits $[18,92]$. Upon binding to the $\mu$-opioid receptor endomorphins activate G-proteins inducing cellular responses including GDP dissociation by GTP on the $G_{\alpha}$ subunit, the reduction of cAMP formation and opening/closure of ion channels [22, 32 and 93]. The efficacies of endomorphins were found to be lower than that of DAMGO in $\left[{ }^{35} \mathrm{~S}\right] \mathrm{GTP} \gamma \mathrm{S}$ binding assays, whereas the efficacy of endomorphins was measured similar to that of morphine [89, 94 and 95]. EM1 partially antagonizes the DAMGO stimulation of $\left[{ }^{35} \mathrm{~S}\right] \mathrm{GTP} \gamma \mathrm{S}$ binding which further confirms the partial agonist property of EM-1 [94]. As shown in various studies, observed efficacies confirmed that endomorphins are partial agonists [57, 79, 94 and 96]. The effects of EM-1 and EM-2 are comparable, only small differences were observed with respect to potency and efficacy in the case of the different cell lines used (SH-SY5Y human neuroblastoma, B82 fibroblast, Chinese hamster ovary (CHO) and C6 glioma cell lines) or rat and mouse brains/spinal cords [9]. In all studies, the effect of endomorphins was found to be reversible by $\mu$-opioid antagonists [91, 92, 97, 98, 99 and 100] whereas $\delta$ - or $\kappa$-antagonists had no significant influence on the effects of these peptides in activating $\left[{ }^{35} \mathrm{~S}\right] \mathrm{GTP} \gamma \mathrm{S}$ binding. The stimulation of the $\left[{ }^{35} \mathrm{~S}\right] \mathrm{GTP} \gamma \mathrm{S}$ binding by endomorphins was diminished in homozygous knockout mice, while it was reduced to one-half of the wild-type levels in heterozygous mice [101, 102 and 103]. No stimulation of $\left[{ }^{35} \mathrm{~S}\right] \mathrm{GTP} \gamma \mathrm{S}$ binding was observed by endomorphins with $\delta$-opioid receptor transfected $\mathrm{CHO}$ cells in mouse [103]. These investigations suggest that $\mu$-opioid receptor gene products play a key role in G-protein activation by endomorphins, and $\mu$-opioid receptor densities could be rate-limiting steps in the G-protein activation by the $\mu$-receptor reserve [9]. 


\subsection{Radioactive isotopes as tracers}

Isotope labeling is an essential tool for determining the fate of any given organic compound in a chemical or biochemical system. H, C, O, N and P are important elements in the biological systems. Since most of the organic compounds contain hydrogen and carbon, these isotopes are by far the most widely used in chemical and biological tracer studies. The first experiments with radioactive tracers were conducted in 1913 by György Hevesy and Friedrich A. Paneth. Hevesy was awarded the Nobel Prize in Chemistry in 1943 for his work on the use of isotopes as tracers in the study of chemical processes. Labeled compounds have significant importance in life sciences as tracers such as autoradiography, immunoassay, DNA-analysis and in direct tracing. In addition to this, radionuclides are being used in medical sciences as well. Currently, the medical imaging techniques, which use radionuclides (Transmission Tomography - CT, Emission Computed Tomography - SPECT, PET) are widely applied diagnostic methods in medicine. Radiotracers are also used for therapy such as internal or external sources.

The advantages of radioisotopes used as radiotracers are that they are chemically identical with the stable isotopes of the same element. The difference in the mass of the nucleus between the various isotopes does cause some change in the chemical and physical properties, but in most cases the isotope effect is rather small and difficult to detect. The radiotracers do not affect the system and can be used in nondestructive techniques and if the tracer is radiochemically pure, interference from other elements is of no concern [104].

Among the isotopes available, tritium-labeled ligands have proved to be essential for the in vitro characterization, autoradiographic localization and distribution studies of the receptors and biodegradation assays in opioid research. Tritium has become an important isotope for labeling ligands, having several advantages such as that the half-life of tritium (12.37 year) is relatively high and that tritium labeled compounds have a high specific radioactivity. The compounds with high specific radioactivity are useful for many biological investigations. Tritium labeling chemistry is often simple and labeling 
can usually be accomplished very late in the overall synthesis, thus minimizing the radiochemical handling required.

\subsection{Tritium and tritium labeling methods of peptides}

The existence of tritium was first predicted in the late 1920s by W. Russell, using his "spiral" periodic table, and then produced in 1934 from deuterium, another isotope of hydrogen, by E. Rutherford, working with M. Oliphant and P. Harteck. Rutherford was unable to isolate the tritium; the job was left to L. Alvarez and R. Cornog (1939) who correctly deduced that the substance was radioactive [105].

Tritium is a soft $\beta$-emitting radionuclide with low energy and low toxicity. The most advantageous property of tritiated compounds as tracers is the high stability of the tritium label under experimental conditions. Furthermore, its decay product, ${ }^{3} \mathrm{He}$, is harmless. Hence, this hydrogen isotope is the safest radioactive nuclide in life sciences. Since having a high half-life (12.37 years), one tritium atom incorporated per molecule represents a specific radioactivity of $1.08 \mathrm{TBq} / \mathrm{mmol}(29.18 \mathrm{Ci} / \mathrm{mmol})$. This value is appropriate for the study of neuropeptides in the nano- and subnanomolar ranges.

There are two basic methods for introducing tritium into organic molecules: the exchange method and the synthetic method [106]. The exchange reactions of ${ }^{3} \mathrm{H} / \mathrm{H}$ isotope do not require separate synthetic steps. The disadvantage of this method is that the compounds are randomly labeled and high percent of impurities are formed during radiolytic side reactions. The main synthetic methods for tritium labeling of neuropeptides [107] include $\beta$-radiation induced isotope exchange reactions [108], catalytic isotope exchange [109] and chemical or enzymatic synthesis from precursor peptides or labeled amino acids, methylation of peptides with ${ }^{3} \mathrm{H}$-methyl iodide [110] or reductive methylation using tritiated metal hydrides [111]. 
The appropriate precursor peptides can be obtained by postsynthetic modifications or by direct synthesis. Most of the precursor peptides for tritiation can be obtained by peptide synthesis using halogen containing saturatred or unsaturated amino acids. The amino acids most frequently used as precursors are 3',5'-diiodotyrosine and 3',5'-dibromotyrosine, $p$-iodophenylalanine or other parahalogenated phenylalanine [112], 2',4'-diiodohistidine [113], 5',7'-dibromotryptophan [114], dehydroproline [115], dehydroleucine [116], dehydroisoleucine [117], 2-aminocyclopentenecarboxylicacid [118], 2-aminocyclohexenecarboxylicacid [119] and propargyl or allyl-glycine [120]. The schematic structures of these amino acids are represented in Figure 2. 
<smiles>[X]c1cc(CC(N)C(=O)O)cc([X])c1O</smiles>

$\mathrm{X}=\mathrm{Br}, 3^{\prime}, 5^{\prime}$-dibromotyrosine $X=I$., 3',5'-dibromotyrosine<smiles>[X]c1c(O)c([X])c(CC(N)C(=O)O)c(C)c1O</smiles>

$\mathrm{X}=\mathrm{Br}, 3^{\prime}, 5^{\prime}$-dibromo-2',6'dimethyltyrosine<smiles>[X]c1ccc(CC(N)C(=O)O)cc1</smiles>

$\mathrm{X}=\mathrm{Cl}$, para-chlorophenylalanine $\mathrm{X}=\mathrm{Br}$, para-bromophenylalanine $\mathrm{X}=\mathrm{I}$, para-iodoophenylalanine<smiles>NC(Cc1c[nH]c2c(Br)cc(Br)cc12)C(=O)O</smiles>

5'7'-dibromotryptophane<smiles>NC(Cc1nc(I)[nH]c1I)C(=O)O</smiles>

2',4'-diiodohistidine<smiles>O=C(O)[C@@H]1C=CCN1</smiles>

3, 4-dehydro-proline 2-aminocyclopent-3-ene carboxylic acid $(\triangle \mathrm{Acpc})$<smiles>C=C(C)CC(N)C(=O)O</smiles>

4,5-dehydroleucine<smiles>N[C@@H]1C=CC[C@H]1C(=O)O</smiles><smiles>N[C@H]1CCC=C[C@H]1C(=O)O</smiles>

2-aminocyclohex-5-ene carboxylic acid $(\triangle \mathrm{Achc})$<smiles>C=CCC(N)C(=O)O</smiles>

Allyl glycine

Figure 2. Amino acid derivatives used for synthesis of precursor peptides for tritiation 


\section{Aims and scope}

Our research group has been working for years in the development of Dmt, Acpc, Achc, $\beta \mathrm{MePhe}$ and $\mathrm{pFPhe}$ containing endomorphin analogues in order to use as therapeutic opioid drugs. Introduction of alicyclic $\beta$-amino acids in the second position yielded proteolytically stable analogues with retained or enhanced biological activities based on the chirality of the incorporated amino acid [58]. By systematic incorporation of one unnatural amino acid in the sequence of endomorphins, analogues were synthesized and their pharmacological properties were reported previously $[58,59,67,68,118,119$ and 121]. Designing the analogues with possible combination of these unnatural amino acids in the sequence could provide useful information in terms of pharmacological properties. By considering these facts, our aims were:

To synthesize new endomorphin analogues with possible combination of $\mathrm{Dmt}^{1}, \mathrm{Achc}^{2}, \Delta \mathrm{Achc}^{2} / \Delta \mathrm{Acpc}^{2}, \beta \mathrm{Pro}^{2}, \mathrm{Hyp}^{2}, \beta \mathrm{MePhe}^{4}$ and $\mathrm{pFPhe}^{4}$ in order to obtain proteolytically stable and biologically active analogues.

To investigate the affinities and selectivities of the newly synthesized analogues in radioligand receptor-binding studies.

To test the functional properties of the highly potent analogues (selection based on receptor-binding assays results) in $\left[{ }^{35} \mathrm{~S}\right] \mathrm{GTP} \gamma \mathrm{S}$ binding assay.

To evaluate the enzymatic resistance of the highly potent analogues (selection based on receptor-binding and $\left[{ }^{35} \mathrm{~S}\right] \mathrm{GTP} \gamma \mathrm{S}$ binding assay results) against proteolytic degrading enzymes, such as dipeptidyl peptidase IV carboxypeptidase Y, amino peptidases etc..

To find out possible bioactive conformational structure(s) in relation with ligand-receptor interactions for $\mu$-opioid receptor binding. 
$\checkmark \quad$ To characterize blood-brain barrier permeabilities using tritiated EM-2 analogues.

$\checkmark \quad$ To test the analgesic properties of highly potent EM-2 analogues in in vivo chronic joint pain model.

$\checkmark \quad$ To perform structure-activity studies of highly potent EM-2 analogues to find out possible conformation(s) for $\mu$-opioid receptor activity. 


\section{Materials and methods}

\subsection{Chemicals}

The Boc-protected amino acids (with the exception of eßMePhe that was synthesized in our laboratory [68]) and 4-methylbenzhydralamine (MBHA) resin were purchased from Sigma-Aldrich Kft. (Budapest, Hungary) or from Bachem Feinchemikalen AG (Bubendorf, Switzerland). Boc- $\beta$ Pro was purchased from Polypeptide Group (Strasbourg, France). cis-(1S,2R)Achc was purchased form Peptides NeoMPS, USA in optical pure form. Racemic cis- $(1 S, 2 R) /(1 R, 2 S)$ Achc was synthesized, purified and kindly provided by Prof. Ferenc Fülöp (University of Szeged, Hungary). Silica gel $60 \mathrm{~F}_{254}$ TLC plates were purchased from Merck (Darmstadt, Germany). Chiral TLC plates were purchased from Macherey-Nagel (Dürer, Germany). N,Ndicyclohexylcarbodiimide (DCC) and N-hydroxybenzotriazole (HOBt) were purchased from Calbiochem-Novabiochem AG (Läufelfingen, Switzerland). Trifluoroacetic acid (TFA), dichloromethane (DCM), dimethylformamide (DMF), diisopropylethylamine (DIEA), ninhydrin, acetonitrile (ACN) and triethylamine (TEA) were purchased from Merck Kft. (Budapest, Hungary). Acetic acid (AcOH), methanol $(\mathrm{MeOH})$, ethanol (EtOH) was delivered by Molar Kft. (Budapest, Hungary). All solvents were of analytical grade. Hydrogen fluoride was obtained form PRAXAIR N.V. (Oevel, Belgium). Guanosine-5'-O-(3-thio)triphosphate (GTP $\gamma \mathrm{S})$ was purchased from Amersham (GE Healthcare, United Kingdom). GF/B and GF/C filter papers were obtained from Whatman International Ltd. (Maidstone England, England). Tris-(hydroxymethyl)aminomethane (Tris, free base), Bradford reagent, bovine serum albumin (BSA), sucrose, guanosine $5^{\prime}$-[ $[\beta, \gamma$-imido]-triphosphate trisodium salt, hydrochloric acid $(\mathrm{HCl} 37 \%)$ and anisole were purchased from Sigma-Aldrich Kft. (Budapest, Hungary). The dimethylsulfoxide (DMSO-d6) used for the ${ }^{1} \mathrm{H}-\mathrm{NMR}$ analysis was purchased from Cambridge isotopes. [ $\left.{ }^{3} \mathrm{H}\right] \mathrm{DAMGO}(1.6 \mathrm{TBq} / \mathrm{mmol}, 43 \mathrm{Ci} / \mathrm{mmol})[122],\left[{ }^{3} \mathrm{H}\right] \mathrm{Ile}{ }^{5,6}$ deltorphin-2 $(1.5 \mathrm{TBq} / \mathrm{mmol}, 39 \mathrm{Ci} / \mathrm{mmol})$ [123] radioligands were prepared in our laboratory from the appropriate halogenated peptide derivatives. Radiolabeled 
$\left[{ }^{35} \mathrm{~S}\right] \mathrm{GTP} \gamma \mathrm{S}(>1000 \mathrm{Ci} / \mathrm{mmol})$ was obtained from Institute of Isotopes Co., Ltd, (Budapest, Hungary).

\subsection{Analytical methods}

The analytical TLC (Thin Layer Chromatography) was performed on silica gel 60 $\mathrm{F}_{254}$ or on chiral TLC plates using the following solvent systems: (A) acetonitrile/methanol/water (4:1:1), (B) 1-butanol/acetic acid/water (4:1:1). The spots were visualized under UV light or with ninhydrin reagent. Analysis and separation of all compounds were performed with a complete HPLC system consisting of an L-7100 pump (Merck, KGaA, Darmstadt, Germany), a SIL-6B auto sampler (Shimadzu Co., Kyoto, Japan), a Shimadzu SCL-6B system controller, and a Merck 1-7400 UV-vis detector, operating at $216 \mathrm{~nm}$ with a Hitachi D-7000 HPLC system manager. For radioligands, a Jasco PU-980 Intelligent HPLC pump, a Jasco LG-980-02 ternary gradient unit, a Jasco UV-975 Intelligent UV/VIS detector (Jasco International Co., Tokyo, Japan) and a Packard A-500 radiochromatography detector were applied (Packard BioScience Co., Meriden, CT, USA) with an Ultima-flo M liquid scintillation cocktail. The samples were analyzed on a Altima $218 \mathrm{TP} 54$ analytical $\mathrm{C}_{18}$ reverse phased column $218 \mathrm{TP} 54(250 \mathrm{~mm} \times 4.6 \mathrm{~mm}, 5 \mu \mathrm{m}, 300 \AA$ pore size $)$ with a flow rate of $1 \mathrm{~mL} / \mathrm{min}$. The compounds were separated on a semipreparative Vydac 218TP1010 column $(250 \mathrm{~mm} \times$ $10 \mathrm{~mm}, 12 \mu \mathrm{m}$ ) with a flow rate of $4 \mathrm{~mL} / \mathrm{min}$. The mobile phase was composed of $0.1 \%$ $(\mathrm{v} / \mathrm{v})$ TFA in water and $0.08 \%(\mathrm{v} / \mathrm{v})$ TFA in acetonitrile with gradient from $20 \%$ up to 60 $\%$ ACN during $30 \mathrm{~min}$. The identities of all peptides were confirmed by respective molecular weights and their purities were found to be $>98 \%$. The molecular weight of the peptides was determined by ESI-MS and HRMS. HRMS spectra were collected on a Waters QTOF Premier mass spectrometer (Waters Corporation, Milford, MA), using direct infusion to the nanoelectrospray source. Samples were dissolved in $0.1 \%(\mathrm{v} / \mathrm{v})$ formic acid $/ 20 \%(\mathrm{v} / \mathrm{v})$ acetonitrile/water solvent to a final concentration of $\sim 0.01 \mathrm{mg} / \mathrm{mL}$. The mass spectra were collected in the 50-990 Da range; the spectrometer was calibrated by using the MS/MS fragments of a $100 \mathrm{fmol} / \mu \mathrm{L}\left[\mathrm{Glu}^{1}\right]$-Fibrinopeptide B solution. 
For binding experiments, incubation mixtures were filtered using a M24R Brandel cell harvester (Gaithersburg, MD). Filter-bound radioactivities were detected and measured in a TRI-CARB 2100TR liquid scintillation analyzer (Packard) using biodegradable Optiphase Supermix cocktail developed by PerkinElmer, USA. Inhibitory constants $\left(K_{\mathrm{i}}\right.$, $\mathrm{nM}$ ) were calculated from the competition experiments by using nonlinear least-squares curve fitting and the Cheng-Prusoff equation, [23] potency $\left(\mathrm{ED}_{50}\right)$ and efficacy $\left(E_{\max }\right)$ values were calculated with GraphPad Prism software (version 4.0, San Diego, CA).

\subsection{Peptide synthesis, purification and determination of configuration of the incorporated alicyclic $\beta$-amino acids}

The synthesis of the peptide analogues was performed by manual solid phase technique using N-Boc-protected amino acids and MBHA resin on 0.25 mmol scale. Boc-protected amino acids were added to pre-swelled resin (in $3.0 \mathrm{ml}$ of DCM for 60 min) in 2:1 (mmol) ratio. Coupling agents (HOBt and DCC) were applied in 1:1 (mmol) ratio regarding to amino acid. Unreacted amino acids and coupling agents were removed by washing the resin with dichloromethane (DCM) and ethanol (each $2.5 \mathrm{ml}$ ). The protective groups were removed with a $2.5 \mathrm{ml} \times 2(5$ and $20 \mathrm{~min})$ solution containing $50 \%$ TFA, $48 \%$ DCM and 2\% anisole, followed by neutralization with $2.5 \mathrm{ml} \times 2(2 \mathrm{~min}$ each) solution consisting of 10\% diisopropyl-ethylamine (DIEA) in DCM. Each coupling was monitored by the Kaiser test [124]. The cleavage of the peptides from the resin was accomplished with anhydrous HF $(10 \mathrm{~mL} / \mathrm{g}$ resin) in presence of anisole $(1 \mathrm{~mL} / \mathrm{g}$ resin) and dimethylsulfide $\left(1 \mathrm{~mL} / \mathrm{g}\right.$ resin) at $0^{\circ} \mathrm{C}$ for $60 \mathrm{~min}$. After evaporation of the $\mathrm{HF}$, the resin was washed with diethyl ether to remove the scavengers, and the peptide was diluted in $30 \%(\mathrm{v} / \mathrm{v})$ aqueous acetic acid. Crude peptides were obtained in solid form after lyophilization of the diluted extract (yields 70-80\%). The diastereomers were separated using semipreparative RP-HPLC on a Vydac $218 \mathrm{TP} 1010 \mathrm{C}_{18}$ column. Purities

were found to be over $98 \%$ as assessed by analytical RP-HPLC. Erythro ( $2 S, 3 S$ and $2 R, 3 R) \beta \mathrm{MePhe}$ containing peptides were purified by silica gel column chromatography due to the same retention time of the diastereomers with RP-HPLC. The eluent used for 
compounds 2-5, 11, 12 was DCM/MeOH 80:20 (v/v) and for compounds 13 and 14 the eluent was EtOAC/AcOH 70:30 (v/v). These peptides were further purified by RP-HPLC to obtain maximal purity $(\geq 98 \%)$.

The configuration of the incorporated Acpc/Achc was determined after GITC derivatization of the acidic hydrolysates of the peptides (for acidic hydrolysis, $1 \mathrm{mg}$ of peptide, $1 \mathrm{~mL}$ of $6 \mathrm{M} \mathrm{HCl}, 24 \mathrm{~h}, 110^{\circ} \mathrm{C}$ ) followed by analytical HPLC analysis. The retention times of the derivatized alicyclic $\beta$-amino acid were compared with those of the derivatized $\beta$-amino acid standards [125]. The configuration of $\beta \mathrm{MePhe}$ was determined with chiral TLC after acidic hydrolysates of the peptides using solvent system A. These $\mathrm{R}_{\mathrm{f}}$ values were compared with those of standard optically pure $\beta \mathrm{MePhe}$ isomers [126].

\subsection{Tritium labeling of peptides}

The conditions used in tritium labeling were optimized in inactive circumstances, using hydrogen gas in order to determine proper reaction conditions such as catalyst, reaction time and solvent. Labeling of peptides with tritium was performed in our inhouse designed vacuum apparatus [127] under a fume cupboard. About $2 \mu \mathrm{mol}$ of pure peptide was dissolved in $1 \mathrm{~mL}$ of DMF and $10 \mathrm{mg}$ of catalyst (PdO/BaSO4) was added. In most cases, an excess of TEA was added to neutralize HI formed during the reaction. The reaction vessel was connected to the tritiation manifold frozen with liquid nitrogen and the air was removed by vacuum. Tritium gas $555 \mathrm{GBq}(15 \mathrm{Ci})$ was liberated by heating $\left(300^{\circ} \mathrm{C}\right)$ from uranium tritide and was introduced into the reaction vessel. The reaction mixture was stirred by a magnetic stirrer at room temperature for 1-2 hours. The reaction was terminated by freezing the solution and absorbing the unreacted tritium on pyrophoric uranium. The catalyst was filtered off using Whatmann GF/C glass-fiber filter paper. Labile tritium was removed by repeated evaporation with ethanol/water 1:1 mixture. The crude reaction mixture was analyzed by radio-HPLC. A TRI-CARB 2100TR liquid scintillation analyzer (Packard) was used to determine the total radioactivity of crude radioligand with a biodegradable Optiphase Supermix cocktail 
developed by Perkin-Elmer (USA). The specific activity was determined by means of calibration curve prepared with the appropriate inactive peptide standard. After the determination of specific activity, radiolabeled peptides were stored in liquid nitrogen, showing good stability during long storage (more than 1 year).

\subsection{Animals}

Inbred Wistar rats (male, 250-300 g body weight) were housed in the local animal house of the Biological Research Center (BRC, Szeged, Hungary). Rats were kept in-groups of four, allowed free access to food and water and maintained on a 12:12-h light/dark cycle until the time of sacrifice. Animals were treated according to the European Communities Council Directives (86/609/ECC) and the Hungarian Act for the Protection of Animals in Research (XXVIII.tv. 32.§).

\subsection{Rat brain membrane preparation}

Whole brains minus cerebella were dissected and crude membrane fractions were prepared as published earlier [21]. Briefly, the brains were homogenized in a 30 volumes $(\mathrm{v} / \mathrm{w})$ of ice-cold $50 \mathrm{mM}$ Tris- $\mathrm{HCl}(\mathrm{pH}=7.4)$ buffer with a Teflon-glass Braunhomogenizer at $1500 \mathrm{rpm}$. The homogenate was centrifuged at 20,000 $x \mathrm{~g}$ for 25 minutes and the supernatant was discarded. The resulting pellet was resuspended in the same volume of cold buffer followed by incubation at $37^{\circ} \mathrm{C}$ for 30 minutes to remove endogenous ligands. Centrifugation was then repeated. The final pellets were taken up in 5 volumes of cold $50 \mathrm{mM}$ Tris- $\mathrm{HCl}(\mathrm{pH}=7.4)$ buffer containing $0.32 \mathrm{M}$ sucrose and stored at $-80^{\circ} \mathrm{C}$. Membranes were thawed before use, diluted with the working buffer and centrifuged at $20,000 \mathrm{x}$ g for $25 \mathrm{~min}$ at $4^{\circ} \mathrm{C}$ to remove sucrose. The resulting pellet was homogenized with a Dounce homogenator in 60 volumes of buffer to yield protein concentrations of about $0.3 \mathrm{mg} / \mathrm{ml}$. The protein content of the membrane preparation was determined by the method of Bradford using bovine serum albumin as standard [128]. 


\subsection{Radioligand-binding assay}

In competition binding experiments the conditions were optimized and varied, based on the radioligand applied. Competition binding experiments were performed by incubating rat brain membranes $(0.2-0.5 \mathrm{mg}$ protein/tube $)$ with $\left[{ }^{3} \mathrm{H}\right]$ DAMGO $(1 \mathrm{nM}$, $25^{\circ} \mathrm{C}, 1 \mathrm{~h}, \mathrm{GF} / \mathrm{C}$ filter, glass tubes) or $\left.{ }^{3} \mathrm{H}\right] \mathrm{ll} \mathrm{e}^{5,6}$-deltorphin-2 $\left(2 \mathrm{nM}, 35^{\circ} \mathrm{C}, 45 \mathrm{~min}\right.$., GF/B filter, plastic tubes) and with increasing concentrations $\left(10^{-10}-10^{-5}\right)$ of unlabeled endomorphin analogues. The incubation mixtures were made up to a final volume of 1 $\mathrm{mL}$ with $50 \mathrm{mM}$ Tris- $\mathrm{Cl}$ buffer $(\mathrm{pH}=7.4)$ and samples were incubated in a shaking waterbath at the appropriate temperature. Nonspecific binding was measured with $10 \mu \mathrm{M}$ naloxone and subtracted from the total binding to determine specific binding. Incubation was initiated by the addition of the membrane preparation and stopped by the rapid filtration over Whatman GF/C or GF/B glass fiber filters, using a Brandel Cell Harvester (Gaithersburg, MD, USA). Vials were washed with $3 \times 5 \mathrm{~mL}$ of ice-cold $50 \mathrm{mM}$ Tris-HCl buffer $(\mathrm{pH}=7.4)$, dried at room temperature for $15-20 \mathrm{~min}$. The filter bound radioactivities were measured in an Optiphase Supermix scintillation cocktail using a TRI-CARB 2100TR liquid scintillation counter (Canberra-Packard, Perkin-Elmer Life Sciences 549 Albany Street, Boston MA 02118). The inhibitory constants, $K_{\mathrm{i}}$ values were calculated from the displacement curves by using non-linear least-square curve fitting and the Cheng-Prusoff equation with GraphPad Prism software (version 4.0, San Diego, $\mathrm{CA})$. The data were expressed as means \pm SEM of at least three independent measurements, each performed in duplicate. 


\subsection{Ligand-stimulated $\left[{ }^{35} \mathrm{~S}\right] \mathrm{GTP} \gamma \mathrm{S}$ functional binding assay}

Rat brain membranes (10-15 $\mu \mathrm{g}$ protein/tube) were incubated with $0.05 \mathrm{nM}$ $\left[{ }^{35} \mathrm{~S}\right] \mathrm{GTP} \gamma \mathrm{S}$ and $10^{-10}-10^{-5} \mathrm{M}$ concentrations of unlabeled ligands in the presence of 30 $\mu \mathrm{M}$ GDP in Tris-EGTA buffer $\left(50 \mathrm{mM}\right.$ Tris-HCl, $100 \mathrm{mM} \mathrm{NaCl}, 3 \mathrm{mM} \mathrm{MgCl}_{2}$ and 1 $\mathrm{mM}$ EGTA, $\mathrm{pH}=7.4)$ at $30^{\circ} \mathrm{C}$ for $60 \mathrm{~min}$ in absence or presence of naloxone $\left(10^{-5} \mathrm{M}\right)$. Basal activity was determined by subtracting the nonspecific binding (measured in the presence of $10 \mu \mathrm{M}$ unlabeled GTP $\gamma \mathrm{S}$ ) from the total binding (measured in the absence of tested compounds). The incubation was started by the addition of $\left[{ }^{35} \mathrm{~S}\right] \mathrm{GTP} \gamma \mathrm{S}$ and was terminated by vacuum filtration through Whatman GF/B glass fiber filters with a Brandel Cell Harvester. Filters were washed with $3 \times 5 \mathrm{~mL}$ of ice-cold $50 \mathrm{mM}$ Tris-HCl buffer $(\mathrm{pH}=7.4)$ and then dried at room temperature for $15-20 \mathrm{~min}$. The radioactivity was counted in an Optiphase Supermix cocktail using a TRI-CARB 2100TR liquid scintillation counter (Canberra-Packard, Perkin-Elmer Life Sciences). Stimulation is given as percentage of the basal activity. The potency $\left(\mathrm{EC}_{50}\right.$ the concentration of the ligand required to elicit the half-maximal effect), and efficacy ( $E_{\max }$, the maximal stimulation of a drug over basal activity) were calculated by using Sigmoidal DoseResponse curve fitting option of GraphPad Prism software (version 4.0, San Diego, CA). The data were expressed as means \pm SEM of at least three independent measurements, each performed in triplicate.

\subsection{Determination of the half-lives}

$20 \mu \mathrm{L}$ of $1 \mathrm{mM}$ peptide stock solution in $50 \mathrm{mM}$ Tris-HCl buffer $(\mathrm{pH}=7.4)$ was added to $180 \mu \mathrm{L}$ of the rat brain homogenate (protein concentration: $5.0 \mathrm{mg} / \mathrm{mL}$ ) and the mixtures were incubated at $37^{\circ} \mathrm{C}$. Aliquots of $20 \mu \mathrm{L}$ were withdrawn from the incubation mixtures and immediately $25 \mu \mathrm{L}$ of $0.1 \mathrm{mM}$ aqueous $\mathrm{HCl}$ solution was added to halt the degradation. After centrifugation $\left(11340 \mathrm{~g}, 5 \mathrm{~min}, 25^{\circ} \mathrm{C}\right)$ of the incubation mixtures, 10 $\mu \mathrm{L}$ of obtained supernatant was analyzed by RP-HPLC. The rate constants $(\mathrm{k})$ of 
degradation were determined by least square linear regression analysis of logarithmic tetrapeptide peak areas $[(\ln (\mathrm{A} / \mathrm{Ao})]$ vs time courses, with minimum of five time points. The obtained rate constants were used to establish the degradation half-lives $\left(t_{1 / 2}\right)$ as $\ln 2 / k$.

\subsection{Study of BBB of some endomorphin analogues}

\section{a. Determination of n-octanol/water partition coefficient}

The values of n-octanol/water partition coefficients $(\log P)$, characterizing the hydrophobicity of the synthesized peptides, were expressed as the ratio of peptide concentration found in the octanol phase to that found in the aqueous phase. Equal volumes of n-octanol and 0.05 M HEPES buffer in $0.1 \mathrm{M} \mathrm{NaCl}, \mathrm{pH}=7.4$, were mixed and allowed to equilibrate for $12 \mathrm{~h}$. The layers were then separated and stored at $4^{\circ} \mathrm{C}$. At testing, $0.5 \mathrm{mg}$ of peptides were dissolved in $500 \mu \mathrm{l}$ of $0.05 \mathrm{M}$ HEPES buffer, then 500 $\mu 1$ of n-octanol was added and mixtures were vortexed for 2 min. Samples were centrifuged at $4000 \mathrm{rpm}$ for $1 \mathrm{~min}$. After separation, octanol phase was lyophilized and reconstituted in acetonitrile/water containing 0.1\% TFA. Octanol and aqueous phases were used to quantify peptide content by RP-HPLC (Altima $\mathrm{C}_{18}, 5 \mu \mathrm{m}, 4.6 \mathrm{~mm} \times 250$ $\mathrm{mm}$ ) using linear gradient of $5-60 \%$ solvent B over $25 \mathrm{~min}$. All n-octanol/buffer distribution studies were performed in triplicate.

\section{b. Measurement of the permeability of the peptides}

Transwell filters containing endothelial cells were removed from the plates containing the glial cultures. Filters were washed with Ringer-HEPES solution (150 mM $\mathrm{NaCl}, 5.2 \mathrm{mM} \mathrm{KCl}, 2.2 \mathrm{mM} \mathrm{CaCl}_{2}, 0.2 \mathrm{mM} \mathrm{MgCl}_{2}, 6 \mathrm{mM} \mathrm{NaHCO}_{3}, 5 \mathrm{mM}$ HEPES, 2.8 $\mathrm{mM}$ D-glucose, $\mathrm{pH}=7.4$ ). The peptides were applied in a final concentration of 0.01 $1000 \mu \mathrm{M}$ and $0.381-0.775 \mu \mathrm{Ci} / \mathrm{ml}$ (depending on the specific activity of the radiolabeled 
peptide) to the apical (luminal) side of the endothelial monolayer in Ringer-HEPES. The basolateral (abluminal) side of the filters was loaded with Ringer-HEPES. Samples were taken from the abluminal side after $1 \mathrm{~h}$ incubation at $37^{\circ} \mathrm{C}$ with gentle shaking. All experiments were performed in triplicate.

The radioactivity was measured in a TRICARB 2100TR liquid scintillation analyzer (Packard) using toluol-Triton-x cocktail containing Liquidflour.

For the measurement of permeability coefficient, the peptides were applied to the luminal side in a concentration of $0.01 \mu \mathrm{M}$ and $0.381-0.775 \mu \mathrm{Ci} / \mathrm{ml}$. After $1 \mathrm{~h}$ samples were taken from the abluminal side.

The permeability coefficient was calculated using the following formula:

$P=\frac{d Q}{d T \cdot A \cdot C_{0}}$

(dQ: transported amount, dT: incubation time, A: surface of filter, $\mathrm{C}_{0}$ : initial concentration in the luminal compartment).

The calculated $\mathrm{P}_{\text {total }}$ values were compared to the $\mathrm{P}_{\text {filter }}$ of the empty filter and the real $\mathrm{P}_{\mathrm{e}}$ value for the endothelial monolayer was calculated using the following formula:

$\frac{1}{P_{e}}=\frac{1}{P_{\text {total }}}-\frac{1}{P_{\text {filter }}}$

The permeability of the peptides was compared to the permeability of sodium fluorescein (SF, MW = $376 \mathrm{Da})$ and Evans blue labeled albumin (EBA, MW = $67 \mathrm{kDa})$. The luminal side was loaded with Ringer-HEPES containing $10 \mu \mathrm{g} / \mathrm{ml} \mathrm{SF}, 170 \mu \mathrm{g} / \mathrm{ml}$ Evans blue and $10 \mathrm{mg} / \mathrm{ml} \mathrm{BSA}$. The cells were incubated at $37^{\circ} \mathrm{C}$ for $1 \mathrm{~h}$ with gentle shaking, and samples were collected from the abluminal side. Concentration of SF and EBA was measured using a fluorescent microplate reader with an excitation wavelength of $485 \mathrm{~nm}$ and an emission wavelength of $520 \mathrm{~nm}$ for $\mathrm{SF}$, and 584/680 nm excitation/emission wavelengths for EBA. The permeability coefficient $\left(\mathrm{P}_{\mathrm{e}}\right)$ was calculated similarly. 


\section{Results}

\subsection{Incorporation of unnatural amino acids into endomorphins}

In general, endomorphins are proteolytically less stable, although having the longest half-lives among the known opioid peptides [31, 50, 51 and 76]. It is essential to enhance the CNS entry of endomorphins and their resistance to enzymatic degradation for considering them as valuable therapeutic drugs. In order to increase the proteolytic stability while retaining or enhancing the biological activity of endomorphins, we introduced unnatural amino acids such as 2, 6-dimethyltyrosine ${ }^{1}$ (Dmt), $(2 S, 4 R)$ hydroxyproline $^{2}$ (Hyp), (S)- $\beta$-proline ${ }^{2}$ ( $\beta$ Pro), cis-2-aminocyclohexanecarboxylic acid ${ }^{2}$ (cis-Achc), cis-2-aminocyclopentenecarboxylic $\operatorname{acid}^{2} \quad(c i s-\Delta \mathrm{Acpc}), \quad c i s-2-$ aminocyclohexenecarboxylic $\operatorname{acid}^{2} \quad\left(\right.$ cis- $\Delta$ Achc), erythro- $\beta$-methylphyenylalanine ${ }^{4}$ (eßMePhe) and para-fluoro-phenylalanine ${ }^{4}(\mathrm{pFPhe})$ into the sequence of endomorphins. Incorporated unnatural amino acids structures are presented in Figure 3A and 3B. 
<smiles>Cc1cc(O)cc(C)c1CC(N)C(=O)O</smiles>

$\mathrm{Dmt}^{1}$<smiles>CC(C(N)=O)c1ccccc1</smiles><smiles>NC(CC1C=CC(F)=CC1)C(=O)O</smiles>

Figure 3A. Chemical structures of unnatural amino acids incorporated in analogues 2-8 and 10-16.<smiles>O=C(O)[C@@H]1C[C@@H](O)CN1</smiles>

2-aminocyclopentenecarboxylic acid<smiles>N[C@]1C=CC[C@@]1C(=O)O</smiles>

$(1 S, 2 R) \Delta \mathrm{Acpc}$

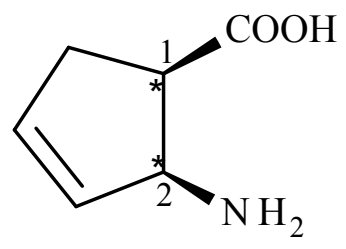

$(1 R, 2 S) \Delta \mathrm{Acpc}$<smiles>O=C(O)C[C@@H]1CCCN1</smiles>

(S)- $\beta$-Pro

2-aminocyclohexenecarboxylic acid<smiles>N[C@]1CC=CC[C@]1C(=O)O</smiles>

$(1 S, 2 R) \Delta$ Achc<smiles>N[C]1CC=CC[C]1C(=O)O</smiles>

$(1 R, 2 S) \Delta$ Achc

Figure 3B. Chemical structures of unnatural amino acids incorporated in second position of EM-2 (analogues 17-21). 


\subsection{Synthesis of novel endomorphin analogues}

All the peptide analogues were synthesized by manual solid phase peptide synthesis method using Boc-protected amino acids. Racemic saturated or unsaturated alicylic $\beta$-amino acids were incorporated with combination of Dmt or $\mathrm{pFPhe}$ to obtain diasteromeric peptide analogues. The analytical properties of the new analogues are reported in Table 3. Erythro- $\beta$ MePhe was used to obtain respective peptide diastereomers. Optically pure cis- $(1 S, 2 R)$ Achc was used for the synthesis of peptides containing $\beta \mathrm{MePhe}$. Racemic unsaturated alicylic $\beta$-amino acids (cis- $\Delta \mathrm{Acpc}$ and cis$\Delta \mathrm{Ach}$ ) were used in respective endomorphin derivatives. The obtained crude peptides indicated that the ratio of the diastereomeric peptides was nearly 1:1. Crude peptides were purified by semi-preparative RP-HPLC. The configuration of cis-alicyclic- $\beta$-amino acids was determined after GITC derivatization of the acidic hydrolysates of the peptides followed by analytical RP-HPLC analysis. The retention times of the derivatized alicyclic $\beta$-amino acid were compared with those of the derivatized $\beta$-amino acid standard [125]. Configuration of $\beta \mathrm{MePhe}$ residues in the peptide analogues was determined by chiral TLC analysis of the acidic hydrolysates of the peptides by comparing $\mathrm{R}_{\mathrm{f}}$ values with those of standard optically pure $\beta \mathrm{MePhe}$ isomers [126]. The $(2 S, 3 S) \beta \mathrm{MePhe}$ isomers had higher $\mathrm{R}_{\mathrm{f}}$ values than those of the corresponding $(2 R, 3 R) \beta \mathrm{MePhe}$ isomers in an eluent mixture of acetonitrile-methanol-water (4:1:1). The molecular weight for all analogues was determined by ESI-MS or High Resolution Mass Spectrometry (HRMS). The identity of all peptides was confirmed and their purities were found to be over $98 \%$ as assessed by analytical RP-HPLC. 
Table 3. Analytical properties (RP-HPLC, TLC and HMRS/ESI-MS data) of endomorphins and their derivatives

\begin{tabular}{|c|c|c|c|c|c|c|}
\hline \multirow[b]{2}{*}{ no. } & \multirow[b]{2}{*}{ Peptide } & \multicolumn{2}{|c|}{ TLC $^{\mathbf{a}}$} & \multirow{2}{*}{$\begin{array}{c}\text { HPL } \\
\mathbf{C}^{\mathbf{b}} \\
\left(\mathbf{k}^{\prime}\right)\end{array}$} & \multirow{2}{*}{$\begin{array}{l}\text { monoisotopoic } \\
\text { mass cal. }\end{array}$} & \multirow{2}{*}{$\begin{array}{c}\text { measure } \\
\text { d } \\
\text { HRMS }\end{array}$} \\
\hline & & $\begin{array}{l}\mathbf{R}_{\mathrm{f}} \\
(\mathbf{A})\end{array}$ & $\begin{array}{l}\mathbf{R}_{\mathbf{f}} \\
(\mathbf{B})\end{array}$ & & & \\
\hline 1 & Tyr-Pro-Trp-Phe-NH ${ }_{2}$ & 0.61 & 0.70 & 3.84 & 610.27 & $611.37^{\mathrm{c}}$ \\
\hline 2 & Tyr- $(1 S, 2 R)$ Achc-Trp- $(2 S, 3 S) \beta M$ MePhe-NH ${ }_{2}$ & 0.55 & 0.83 & 6.09 & 652.3374 & 652.3344 \\
\hline 3 & Tyr- $(1 S, 2 R)$ Achc-Trp- $(2 R, 3 R) \beta$ MePhe-NH $\mathrm{N}_{2}$ & 0.59 & 0.85 & 6.04 & 652.3374 & 652.3419 \\
\hline 4 & Dmt- $(1 S, 2 R)$ Achc-Trp- $(2 S, 3 S) \beta$ MePhe-NH ${ }_{2}$ & 0.52 & 0.84 & 6.47 & 680.3686 & 680.3623 \\
\hline 5 & Dmt- $(1 S, 2 R)$ Achc-Trp- $(2 R, 3 R) \beta$ MePhe- $\mathrm{NH}_{2}$ & 0.59 & 0.84 & 6.39 & 688.3686 & 688.3796 \\
\hline 6 & Tyr-( $1 S, 2 R)$ Achc-Trp-pFPhe-NH ${ }_{2}$ & 0.58 & 0.81 & 6.18 & 656.3123 & 656.3104 \\
\hline 7 & Tyr-( $(1 R, 2 S)$ Achc-Trp-pFPhe-NH ${ }_{2}$ & 0.70 & 0.76 & 4.69 & 656.3123 & 656.3215 \\
\hline 8 & Dmt- $(1 S, 2 R)$ Achc-Trp-pFPhe- $\mathrm{NH}_{2}$ & 0.57 & 0.83 & 6.58 & 684.3435 & 684.3399 \\
\hline 9 & Tyr-Pro-Phe-Phe-NH ${ }_{2}$ & 0.56 & 0.68 & 3.57 & 571.26 & $572.29^{\mathrm{c}}$ \\
\hline 10 & Tyr-( $(1 S, 2 R)$ Achc-Phe- $(2 S, 3 S) \beta \mathrm{MePhe}-\mathrm{NH}_{2}$ & 0.58 & 0.81 & 6.10 & 613.3265 & 613.3291 \\
\hline 11 & Tyr- $(1 S, 2 R)$ Achc-Phe- $(2 R, 3 R) \beta \mathrm{MePhe}-\mathrm{NH}_{2}$ & 0.59 & 0.82 & 6.17 & 613.3265 & 613.3303 \\
\hline 12 & Dmt- $(1 S, 2 R)$ Achc-Phe- $(2 S, 3 S) \beta \mathrm{MePhe}-\mathrm{NH}_{2}$ & 0.51 & 0.83 & 6.58 & 641.3577 & 641.3605 \\
\hline 13 & Dmt- $(1 S, 2 R)$ Achc-Phe- $(2 R, 3 R) \beta$ MePhe- $\mathrm{NH}_{2}$ & 0.59 & 0.85 & 6.48 & 641.3577 & 641.3591 \\
\hline 14 & Tyr-( $1 S, 2 R)$ Achc-Phe-pFPhe-NH ${ }_{2}$ & 0.56 & 0.80 & 6.14 & 617.3014 & 617.3071 \\
\hline 15 & Tyr-( $1 R, 2 S)$ Achc-Phe-pFPhe-NH ${ }_{2}$ & 0.68 & 0.75 & 4.67 & 617.3014 & 617.3107 \\
\hline 16 & Dmt- $(1 S, 2 R)$ Achc-Phe-pFPhe- $\mathrm{NH}_{2}$ & 0.52 & 0.83 & 6.82 & 645.3326 & 645.3371 \\
\hline 17 & Tyr-Hyp-Phe-Phe-NH ${ }_{2}$ & 0.58 & 0.91 & 1.49 & 587 & $588.25^{\mathrm{c}}$ \\
\hline 18 & Tyr- $\beta$ Pro-Phe-Phe-NH ${ }_{2}$ & 0.43 & 0.67 & 1.97 & 585 & $586.28^{\mathrm{c}}$ \\
\hline 19 & Tyr-( $(1 S, 2 R) \Delta$ Acpc-Phe-Phe-NH ${ }_{2}$ & 0.56 & 0.82 & 2.51 & 583 & $584.25^{\mathrm{c}}$ \\
\hline 20 & Tyr-( $(1 R, 2 S) \Delta$ Acpc-Phe-Phe-NH ${ }_{2}$ & 0.67 & 0.71 & 1.71 & 583 & $584.31^{\mathrm{c}}$ \\
\hline 21 & Tyr- $(1 S, 2 R) \Delta$ Achc-Phe-Phe-NH ${ }_{2}$ & 0.50 & 0.76 & 2.65 & 597 & $598.29^{\mathrm{c}}$ \\
\hline 22 & Tyr-( $(1 R, 2 S) \Delta$ Achc-Phe-Phe-NH ${ }_{2}$ & 0.68 & 0.67 & 1.99 & 597 & $598.22^{\mathrm{c}}$ \\
\hline
\end{tabular}

${ }^{a}$ Retention factors on silica gel $60 \mathrm{~F}_{254}$ plates. Solvent systems: (A) 1-butanol/acetic acid/water (4:1:1:), (B) acetonitrile/methanol/water (4:1:1). ${ }^{b}$ Capacity factors for Altima HP $\mathrm{C}_{18}\left(25 \times 0.46 \mathrm{~cm}, \mathrm{~d}_{\mathrm{p}}=5 \mu \mathrm{m}\right)$ column. The gradient was from $20 \%$ up to $60 \%$ ACN during 30 min., at a flow rate of $1 \mathrm{~mL} / \mathrm{min}$., $\lambda=216 \mathrm{~nm}$. ${ }^{\mathrm{c}}$ Measured mass with ESI-MS. 


\subsection{Receptor binding affinities and selectivities of new endomorphin analogues}

The binding affinities and selectivities of the newly synthesized endomorphin analogues were evaluated by radioligand binding assays using rat brain membrane preparations. The opioid prototype, enkephalin derivative $\left[{ }^{3} \mathrm{H}\right] \mathrm{DAMGO}$, a highly selective $\mu$-opioid receptor ligand, was used to evaluate $\mu$-opioid receptor binding

affinities. The synthetic $\left[{ }^{3} \mathrm{H}\right] \mathrm{Il} \mathrm{e}^{5,6}$-deltorphin-2 peptide ligand was used for assessment of $\delta$-receptor affinities. All the new compounds competed with the radiolabeled $\mu$ - and $\delta$ receptor ligands in a concentration dependent manner for the receptor binding sites. The inhibitory constants $\left(K_{\mathrm{i}}\right)$ and selectivities $\left(K_{\mathrm{i}}^{\delta} / K_{\mathrm{i}}^{\mu}\right)$ of the 22 new analogues over the values of the parent ligands are listed in Table 4. EM-1 and -2 were also evaluated for comparison and the values obtained were consistent with literature data [38, 58 and 68]. The representative curves of $\mu$ and $\delta$-opioid receptors of some of highly potent analogues are shown in Figure 4. The analysis of the binding results revealed that the coapplication of $(1 S, 2 R) \mathrm{Achc}^{2}$ and $(2 S, 3 S) \beta \mathrm{MePhe}^{4}$ in both endomorphins resulted comparably potent analogues (compounds 2 and 10) compared to the native peptides. These binding potencies were further enhanced by the combined substitution of $\mathrm{Dmt}^{1}$, $(1 S, 2 R) \mathrm{Achc}^{2}$ and $(2 S, 3 S) \beta \mathrm{MePhe}^{4}$ accomplished in compounds 4 and 12. The results confirmed that single or combined use of $\mathrm{Dmt}^{1}$ increases the affinity for $\mu$-opioid receptor but, at the same time, decreases selectivity of the ligands. Analogues containing the corresponding $(2 R, 3 R) \mathrm{BMePhe}^{4}$ residue exhibited lower affinities than those including the other isomer $(2 S, 3 S) \beta \mathrm{MePhe}^{4}$, however, replacement of $\mathrm{Tyr}^{1}$ with Dmt could enhance the binding potency of the ligands (compounds 5 and 13). Co-substitution with the halogenated $\mathrm{pFPhe}^{4}$ and $\mathrm{Achc}^{2}$ resulted in ligands with different potencies depending on the chirality of the alicyclic $\beta$-amino acids (compounds 6-8, 14-16). In comparison with compounds $\mathbf{5}$ and $\mathbf{1 3}$, it is interesting to note that compound $\mathbf{1 6}$ showed higher potency than its corresponding EM-2 analogue therefore, it can be assumed that only minor differences in structures (Trp/Phe) may be responsible for the observed changes in ligand binding. Furthermore, it is also interesting to mention that $\mathrm{pFPhe}^{4}$ could compensate the detrimental effects of $(1 R, 2 S) \mathrm{Achc}^{2}$ incorporation as it was 
demonstrated for compound $15\left(K_{\mathrm{i}}=2.8 \mathrm{nM}\right)$ and other endomorphin derivatives. Endomorphins containing $(1 R, 2 S) \mathrm{Achc}^{2}$ displayed less $\mu$-opioid receptor affinity $\left(K_{\mathrm{i}}=\right.$ $741 \mathrm{nM}, 1984 \mathrm{nM}$ for EM-1, and -2 respectively) compared to parent compounds [58]. Among the pFPhe ${ }^{4}$ containing analogues, compound 16 displayed the highest $\mu$-opioid receptor affinity with relatively high selectivity. Incorporation of $\mathrm{Hyp}^{2}$ (compound 17) resulted in decreased affinity to $\mu$-opioid receptor $\left(K_{\mathrm{i}}=44 \mathrm{nM}\right)$, in contrast to affinity values measured with opioid selective antagonist naloxone in crude rat brain membrane [129]. Insertion of $(S)-\beta \operatorname{Pro}^{2}$ resulted in lower affinity $\left(K_{\mathrm{i}}=27 \mathrm{nM}\right)$ compared to that of parent EM-2. Unlike EM-2, $\beta$ Pro $^{2}$ containing EM-1 exhibited higher affinity to $\mu$-opioid receptor in rat brain homogenate [130]. Compound $\mathbf{1 9}$ and 21, bearing cis$(1 S, 2 R) \Delta \mathrm{Acpc}^{2} / c i s-(1 S, 2 R) \Delta \mathrm{Achc}^{2}$ displayed higher affinities compared to other isomer $(1 R, 2 S)$. The observed propensity of binding potencies for unsaturated alicyclic $\beta$-amino acids analogues followed the results obtained for respective saturated alicyclic $\beta$-amino acid analogues [58]. Compound 19 exhibited equal affinity $\left(K_{\mathrm{i}}=1.3 \mathrm{nM}\right)$ and high selectivity for $\mu$-opioid receptor relative to the parent EM-2. The rank order of potency measured against $\left[{ }^{3} \mathrm{H}\right] \mathrm{DAMGO}$ was as follows compounds $16<12<10<4<19<9<14<1<15<6<5<2<13<8<18<11<3<20<7<20<22$. Each ligand showed moderate to low binding affinities for $\delta$-opioid receptors, indicating that these modifications provide $\mu$-opioid receptor ligands.
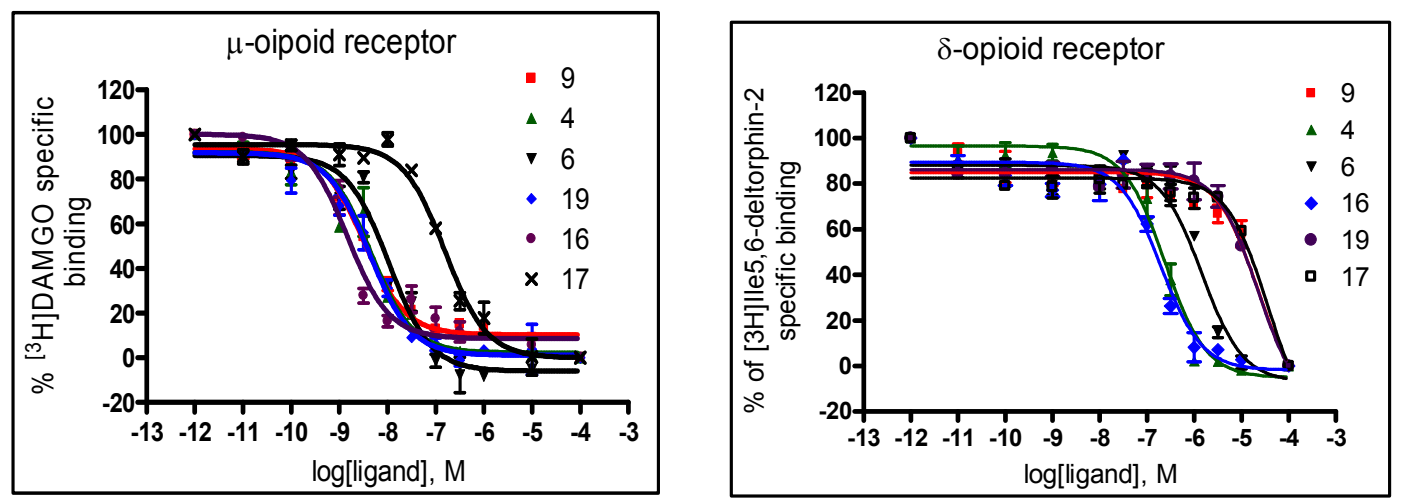

Figure 4. Representative curves of competitive receptor binding of novel endomorphin analogues at $\mu$ - and $\delta$-opioid receptor sites. Points represent the means $\pm S E M$ of at least three different experiments, each performed in duplicate. 
Table 4. Summary of inhibitory constants $\left(K_{\mathrm{i}}\right)$ and selectivity of endomorphins and their analogues measured on rat brain membrane preparation

\begin{tabular}{|c|c|c|c|c|}
\hline \multirow{2}{*}{ no. } & \multirow{2}{*}{ peptide } & \multicolumn{2}{|c|}{ inhibitory constants } & \multirow{2}{*}{$\frac{\text { selectivity }}{K_{\mathrm{i}}^{\delta} / K_{\mathrm{i}}^{\mu}}$} \\
\hline & & $K_{\mathrm{i}}^{\mu}(\mathrm{nM})^{a}$ & $K_{\mathrm{i}}^{\delta}(\mathrm{nM})^{b}$ & \\
\hline 1 & Tyr-Pro-Trp-Phe- $\mathrm{NH}_{2}$ & $1.6 \pm 0.3$ & $4169 \pm 881$ & 2605 \\
\hline 2 & Tyr- $(1 S, 2 R)$ Achc-Trp- $(2 S, 3 S) \beta \mathrm{MePhe}-\mathrm{NH}_{2}$ & $4.2 \pm 0.9$ & $1444 \pm 182$ & 343 \\
\hline 3 & Tyr- $(1 S, 2 R)$ Achc-Trp- $(2 R, 3 R) \beta \mathrm{MePhe}-\mathrm{NH}_{2}$ & $34.6 \pm 3.5$ & $3364 \pm 1093$ & 97 \\
\hline 4 & Dmt- $(1 S, 2 R)$ Achc-Trp- $(2 S, 3 S) \beta \mathrm{MePhe}-\mathrm{NH}_{2}$ & $0.93 \pm 0.07$ & $123 \pm 17$ & 132 \\
\hline 5 & Dmt- $(1 S, 2 R)$ Achc-Trp- $(2 R, 3 R) \beta \mathrm{MePhe}-\mathrm{NH}_{2}$ & $4.11 \pm 0.7$ & $287 \pm 55$ & 69 \\
\hline 6 & Tyr-( $1 S, 2 R)$ Achc-Trp-pFPhe- $\mathrm{NH}_{2}$ & $3.2 \pm 0.5$ & $571 \pm 92$ & 178 \\
\hline 7 & Tyr-(1R,2S)Achc-Trp-pFPhe- $\mathrm{NH}_{2}$ & $143.1 \pm 5.9$ & $7823 \pm 1039$ & 54 \\
\hline 8 & Dmt- $(1 S, 2 R)$ Achc-Trp-pFPhe- $\mathrm{NH}_{2}$ & $11.1 \pm 2.0$ & $2636 \pm 670$ & 237 \\
\hline 9 & Tyr-Pro-Phe-Phe- $\mathrm{NH}_{2}$ & $1.35 \pm 0.2$ & $8771 \pm 1316$ & 6497 \\
\hline 10 & Tyr- $(1 S, 2 R)$ Achc-Phe- $(2 S, 3 S) \beta \mathrm{MePhe}-\mathrm{NH}_{2}$ & $0.82 \pm 0.2$ & $661 \pm 43$ & 816 \\
\hline 11 & Tyr- $(1 S, 2 R)$ Achc-Phe- $(2 R, 3 R) \beta \mathrm{MePhe}-\mathrm{NH}_{2}$ & $33.9 \pm 6.0$ & $1268 \pm 33$ & 37 \\
\hline 12 & Dmt- $(1 S, 2 R)$ Achc-Phe- $(2 S, 3 S) \beta \mathrm{MePhe}-\mathrm{NH}_{2}$ & $0.47 \pm 0.06$ & $142 \pm 8$ & 302 \\
\hline 13 & Dmt- $(1 S, 2 R)$ Achc-Phe- $(2 R, 3 R) \beta \mathrm{MePhe}-\mathrm{NH}_{2}$ & $9.7 \pm 1.3$ & $198 \pm 48$ & 20 \\
\hline 14 & Tyr-( $1 S, 2 R)$ Achc-Phe-pFPhe- $\mathrm{NH}_{2}$ & $1.5 \pm 0.3$ & $366 \pm 61$ & 244 \\
\hline 15 & Tyr-(1R,2S)Achc-Phe-pFPhe- $\mathrm{NH}_{2}$ & $2.8 \pm 0.5$ & $689 \pm 98$ & 246 \\
\hline 16 & Dmt- $(1 S, 2 R)$ Achc-Phe-pFPhe- $\mathrm{NH}_{2}$ & $0.13 \pm 0.02$ & $96 \pm 9$ & 738 \\
\hline 17 & Tyr-Hyp-Phe-Phe- $\mathrm{NH}_{2}$ & $44 \pm 3.4$ & $>10000$ & - \\
\hline 18 & Tyr- $\beta$ Pro-Phe-Phe- $\mathrm{NH}_{2}$ & $27 \pm 2.6$ & $>10000$ & - \\
\hline 19 & Tyr- $(1 S, 2 R) \Delta$ Acpc-Phe-Phe- $\mathrm{NH}_{2}$ & $1.3 \pm 0.2$ & $9935 \pm 1218$ & 7642 \\
\hline 20 & Tyr- $(1 R, 2 S) \Delta$ Acpc-Phe-Phe-NH ${ }_{2}$ & $2158 \pm 213$ & $>10000$ & - \\
\hline 21 & Tyr- $(1 S, 2 R) \Delta$ Achc-Phe-Phe-NH ${ }_{2}$ & $2.6 \pm 0.2$ & $1028 \pm 121$ & 395 \\
\hline 22 & Tyr- $(1 R, 2 S) \Delta$ Achc-Phe-Phe- $\mathrm{NH}_{2}$ & $2299 \pm 372$ & $>10000$ & - \\
\hline
\end{tabular}

${ }^{\mathrm{a}}\left[{ }^{3} \mathrm{H}\right]$ DAMGO $\left(\mathrm{K}_{\mathrm{d}}=0.5 \mathrm{nM}\right)$ was used as radioligand for the $\mu$-opioid receptor. ${ }^{\mathrm{b}}\left[{ }^{3} \mathrm{H}\right] \mathrm{Il} \mathrm{e}^{5,6}$ deltorphin-2 $\left(\mathrm{K}_{\mathrm{d}}=\right.$ $2.0 \mathrm{nM}$ ) was used as a radioligand for the $\delta$-opioid receptor. $K_{\mathrm{i}}$ values were calculated according to the Cheng-Prusoff equation: $K_{\mathrm{i}}=\mathrm{EC}_{50} /\left(1+[\right.$ ligand $\left.] / K_{\mathrm{d}}\right)$. Data are expressed as means $\pm \mathrm{SEM}, n \geq 3$. 


\section{4. $\left[{ }^{35} \mathrm{~S}\right] \mathrm{GTP} \gamma \mathrm{S}$ functional assay of the new endomorphin analogues}

On the basis of the heterologous displacement binding results, the most potent analogues were selected for $\left[{ }^{35} \mathrm{~S}\right] \mathrm{GTP} \gamma \mathrm{S}$ functional assays. The results of the ligandstimulated $\left[{ }^{35} \mathrm{~S}\right] \mathrm{GTP} \gamma \mathrm{S}$ functional assays are summarized in Table 5. From the pool of ligands, compounds $2,4,6,8,10,12,14$ and 16 , and the parent peptides were undertaken to overall functional characterization and comparison. Representative curves of G-protein stimulation of some of the ligands were shown Figure 5. To confirm opioid receptor functionality, the newly synthesized ligands were also assayed in the presence of the opioid selective antagonist naloxone. Potency $\left(\mathrm{EC}_{50}\right)$ and efficacy $\left(E_{\max }\right)$ values were compared with those of the $\mu$-receptor full agonist DAMGO (compound 0). Dosedependent increases were observed for the selected compounds in $\left[{ }^{35} \mathrm{~S}\right] \mathrm{GTP} \gamma \mathrm{S}$ binding. Both parent ligands exhibited comparable potencies, but lower efficacies ( $E_{\max }=149 \%$ for EM-1 and $E_{\max }=163 \%$ for EM-2) could be observed as compared to DAMGO, confirming that endomorphins are partial agonists, as reported earlier [94, 96, 131 and 132]. Compounds 6, 10 and 16 displayed the highest efficacies $\left(E_{\max }=174 \%, E_{\max }=173 \%\right.$, $E_{\max }=176 \%$, respectively), acting as full agonists. Additionally, compound 16 showed four times higher potency $\left(\mathrm{EC}_{50}=51 \mathrm{nM}\right)$ than that of EM-2 $\left(\mathrm{EC}_{50}=212 \mathrm{nM}\right)$. Compounds 2, 4, 8, 12 and 14 revealed slightly less efficacies than that of DAMGO, which indicate partial agonist or full agonist properties. Interestingly, compound $\mathbf{1 2}$ displayed the highest potency $\left(\mathrm{EC}_{50}=17 \mathrm{nM}\right)$ among all analogues. All analogues moderately stimulated G-protein activation. Compound 17 had moderate efficacy ( $E_{\max }=148 \%$ ), suggesting that it is a weak partial agonist. The lowest efficacy $\left(E_{\max }=116 \%\right)$ was observed for compound $\mathbf{1 8}$ among all new analogues, suggesting it is a moderate agonist. Compound 19 displayed comparable efficacy $\left(E_{\max }=170 \%\right)$ with $\mu$-receptor selective agonist DAMGO $\left(E_{\max }=173 \%\right)$, proposing a full agonist property. Compound 21 showed efficacy $\left(E_{\max }=162 \%\right)$ comparable to the parent EM-2, acting as a partial agonist. In the case of EM-1, insertion of $\beta$ Pro $^{2}$ yielded a peptide with an increased efficacy, acting as an agonist [87]. Interestingly, compounds 4, 12 and 16 stimulated G-protein binding even in the presence of $10^{-5} \mathrm{M}$ naloxone (data not shown) therefore, we hypothesized that these ligands may bind to other G-protein coupled receptors or to non-opioid binding sites. The 
rank order of efficacy $\left(E_{\max }\right)$ measured by $\left[{ }^{35} \mathrm{~S}\right] \mathrm{GTP} \gamma \mathrm{S}$ functional assay was: compounds $0>16>6>10>19>14>8=9>2=4=21>12>1>17>18$.

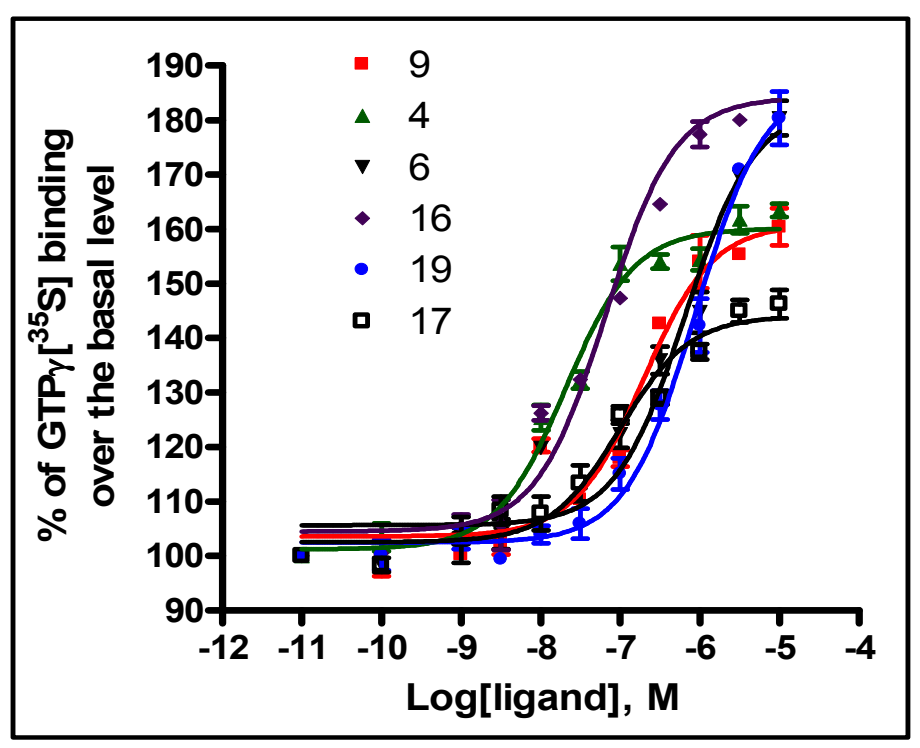

Figure 5. Stimulation of G-proteins by novel endomorphin analogues in rat brain membranes. Basal activity (basal = 'total binding' - 'nonspecific binding') is taken as 100\%. Nonspecific binding is determined in the presence of $10 \mu M$ unlabeled GTP $\gamma$ S. Points represent the means \pm SEM of at least three independent measurements, each performed in triplicate. 
Table 5. Summary of $\left[{ }^{35} \mathrm{~S}\right] \mathrm{GTP} \gamma \mathrm{S}$ functional assays with selected endomorphin analogues measured in a rat brain membrane preparation

\begin{tabular}{|c|c|c|c|}
\hline no. & peptide & $\mathrm{EC}_{50}(\mathrm{nM})$ & $E_{\max }(\%)$ \\
\hline $\mathbf{0}$ & DAMGO & $214 \pm 39$ & $178 \pm 5$ \\
\hline 1 & Tyr-Pro-Trp-Phe-NH ${ }_{2}$ & $166 \pm 27$ & $149 \pm 4^{\mathrm{ns}}$ \\
\hline 2 & Tyr-(1S,2R)Achc-Trp- $(2 S, 3 S) \beta \mathrm{MePhe}-\mathrm{NH}_{2}$ & $264 \pm 8$ & $162 \pm 2^{\mathrm{ns}}$ \\
\hline 4 & Dmt-( $1 S, 2 R)$ Achc-Trp-( $2 S, 3 S) \beta M e P h e-\mathrm{NH}_{2}$ & $22.1 \pm 3$ & $162 \pm 9^{\mathrm{ns}}$ \\
\hline 6 & Tyr-( $1 S, 2 R)$ Achc-Trp-pFPhe-NH ${ }_{2}$ & $380 \pm 38$ & $174 \pm 9^{\mathrm{ns}}$ \\
\hline 8 & Dmt- $(1 S, 2 R)$ Achc-Trp-pFPhe-NH ${ }_{2}$ & $8.1 \pm 3$ & $163 \pm 13^{\text {ns }}$ \\
\hline 9 & Tyr-Pro-Phe-Phe-NH ${ }_{2}$ & $212 \pm 6$ & $163 \pm 6^{\mathrm{ns}}$ \\
\hline 10 & Tyr- $(1 S, 2 R)$ Achc-Phe- $(2 S, 3 S) \beta \mathrm{MePhe}-\mathrm{NH}_{2}$ & $273 \pm 31$ & $173 \pm 6^{\mathrm{ns}}$ \\
\hline 12 & Dmt- $(1 S, 2 R)$ Achc-Phe- $(2 S, 3 S) \beta$ MePhe-NH ${ }_{2}$ & $17 \pm 5$ & $159 \pm 4^{\mathrm{ns}}$ \\
\hline 14 & Tyr-(1S,2R)Achc-Phe-pFPhe-NH ${ }_{2}$ & $92 \pm 8$ & $168 \pm 6^{\mathrm{ns}}$ \\
\hline 16 & Dmt- $(1 S, 2 R)$ Achc-Phe-pFPhe-NH ${ }_{2}$ & $51 \pm 8$ & $176 \pm 7^{\mathrm{ns}}$ \\
\hline 17 & Tyr-Hyp-Phe-Phe-NH ${ }_{2}$ & $66 \pm 38$ & $148 \pm 9^{\text {ns }}$ \\
\hline 18 & Tyr- $\beta$ Pro-Phe-Phe- $\mathrm{NH}_{2}$ & $845 \pm 109$ & $116 \pm 2^{* * *}$ \\
\hline 19 & Tyr- $(1 S, 2 R) \Delta$ Acpc-Phe-Phe- $\mathrm{NH}_{2}$ & $345 \pm 12$ & $170 \pm 12^{\text {ns }}$ \\
\hline 21 & Tyr- $(1 S, 2 R) \Delta$ Achc-Phe-Phe-NH ${ }_{2}$ & $1024 \pm 3$ & $162 \pm 6^{\mathrm{ns}}$ \\
\hline
\end{tabular}

Sigmoid dose-response curves of the listed peptides were determined as described in the Methods section. $\mathrm{EC}_{50}$ and $E_{\max }$ values were calculated by using the sigmoid dose-response fitting option of the GraphPad Prism software. The concentration of naloxone used to block ligand binding and subsequent G-protein activation was set at $10^{-5} \mathrm{M}$. Data are expressed as the $\%$ stimulation of the basal activities in the absence of peptides, which was defined as $100 \%$. Data are means \pm SEM, $n \geq 3$, each performed in triplicate. $* * *=$ $\mathrm{P}<0.001$ as assessed by ANOVA and Bonferroni's post hoc test (compared to DAMGO). 


\subsection{Enzymatic degradation}

The stability studies of the most potent analogues towards enzymatic degradation were performed in rat brain homogenate. Compound $\mathbf{1 7}$ displayed a 3 fold higher halflife $(17 \mathrm{~min})$ relative to the parent compound EM-2. Insertion of $\beta$-homoproline (compound 18) lead to an increase of 6 folds in stability, compared to the parent compound EM-2. In accordance with literature data, analogues containing alicyclic $\beta$ amino acids have shown prolonged half-lives $\left(t_{1 / 2}=>20 \mathrm{~h}\right)$ in contrast with the parent endomorphins $\left(t_{1 / 2}=5-7 \mathrm{~min}\right)$, pointing to the enzyme resistance of the new analogues. These results are summarized in Table 6.

Table 6. Half-lives of the endomorphins and their potent analogues in crude rat brain membrane homogenate

\begin{tabular}{|c|c|c|}
\hline no. & peptide & half-life \\
\hline 1 & Tyr-Pro-Trp-Phe-NH ${ }_{2}$ & $6.3 \pm 0.1 \mathrm{~min}$ \\
\hline 2 & Tyr- $(1 S, 2 R)$ Achc-Trp- $(2 S, 3 S) \beta$ MePhe- $\mathrm{NH}_{2}$ & $>20 \mathrm{~h}$ \\
\hline 6 & Tyr-( $1 S, 2 R)$ Achc-Trp- $p$ FPhe-NH ${ }_{2}$ & $>20 \mathrm{~h}$ \\
\hline 9 & Tyr-Pro-Phe-Phe-NH ${ }_{2}$ & $5.7 \pm 0.1 \mathrm{~min}$ \\
\hline 12 & Dmt- $(1 S, 2 R)$ Achc-Phe- $(2 S, 3 S) \beta$ MePhe-NH ${ }_{2}$ & $>20 \mathrm{~h}$ \\
\hline 16 & Dmt- $(1 S, 2 R)$ Achc-Phe- $p$ FPhe- $\mathrm{NH}_{2}$ & $>20 \mathrm{~h}$ \\
\hline 17 & Tyr-Hyp-Phe-Phe-NH ${ }_{2}$ & $17 \pm 0.9 \mathrm{~min}$ \\
\hline 18 & Tyr- $\beta$ Pro-Phe-Phe- $\mathrm{NH}_{2}$ & $34 \pm 3 \min$ \\
\hline 19 & Tyr- $(1 S, 2 R) \Delta$ Acpc-Phe-Phe- $\mathrm{NH}_{2}$ & $>20 \mathrm{~h}$ \\
\hline 21 & Tyr- $(1 S, 2 R) \Delta$ Achc-Phe-Phe- $\mathrm{NH}_{2}$ & $>20 \mathrm{~h}$ \\
\hline
\end{tabular}

Data are means of at least three individual experiments \pm S.E.M. The protein content of the brain homogenate was $5.0 \mathrm{mg} / \mathrm{mL}$. Half-lives were calculated on the basis of pseudo-first-order kinetics of the disappearance of the peptides. 


\subsection{In vitro $\mathrm{BBB}$ permeability of EM-2 analogues by brain capillary endothelial cells}

The BBB plays a significant role in the treatment of CNS disorders [30]. It is widely accepted that the mediation of analgesic effects occurs within the CNS, therefore opioid peptides should be able to cross the BBB intact. In order to obtain improved proteolytic stabilities and increased BBB permeabilities, we have synthesized and tritiated three EM-2 analogues: peptide-1 [Dmt-Pro-Phe-Phe- $\mathrm{NH}_{2}$ ], peptide-2 [Tyr$(1 S, 2 R)$ Acpc-Phe-Phe- $\left.\mathrm{NH}_{2}\right], \quad$ peptide-3 [Tyr-(1S,2R)Achc-Phe-Phe- $\left.\mathrm{NH}_{2}\right] . \quad$ These analogues were subjected to asses BBB permeability through rat cerebral endothelial cell layer and the cytotoxic effect of these peptides on endothelial cells were studied. This work was done in collaboration with Dr. István Krizbai and Dr. Imola Wilhelm, Institute of Biophysics, Biological Research Centre, Szeged, Hungary. The series of peptides used in the BBB studies was not specified in the previous chapters. The analogues were chosen based on their improved pharmacological activity evaluated previously in our laboratory [58, 59]. Lipophilicity, is an important factor in the diffusion of the compounds through the BBB. A correlation was observed between the lipophilicity and the structure of the compounds. However, no correlation was observed between lipophilicity and permeabilities. Inhibitory constants $\left(K_{\mathrm{i}}\right)$, selectivities, mass spectrometry analysis, half-life and liphophilicites of measured compounds are listed in Table 7. The rate of transendothelial transport of the peptides from the luminal (blood) side to the abluminal (brain) side are characterized by the following $\mathrm{P}_{\mathrm{e}}$ values: the $\mathrm{P}_{\mathrm{e}}$ of EM-2 was $7.84 \times 10^{-6} \pm 0.73 \times 10^{-6} \mathrm{~cm} / \mathrm{s}$ (average $\pm \mathrm{SEM}$ ), which was approximately two times higher than the permeability of sodium fluorescein $(\mathrm{SF})\left(\mathrm{P}_{\mathrm{e}}=3.83 \times 10^{-6} \pm 0.84 \times 10^{-6} \mathrm{~cm} / \mathrm{s}\right)$, which has low BBB permeability and is generally used for the assessment of the integrity of the barrier. The permeability of Evans blue labeled albumin (EBA), which is considered a BBB-impermeable marker, was one order of magnitude lower $\left(\mathrm{P}_{\mathrm{e}}=7.8 \times 10^{-7}\right.$ $\pm 2.1 \times 10^{-7} \mathrm{~cm} / \mathrm{s}$ ). All of the analogues showed a significantly increased permeability in comparison with EM-2 (Figure 6). In addition to this, cytotoxic effect of these peptides was characterized in brain endothelial cells using a wide range of concentrations 
(between $10 \mathrm{nM}$ and $1 \mathrm{mM}$ ). None of the peptides affected the viability of the cells significantly, not even in the highest concentrations, suggesting no cytotoxic effect [133].

Table 7. Inhibitory constants $\left(K_{\mathrm{i}}\right)$, selectivities, half-life and $\log P$ values of EM-2 and its analogues used in the BBB studies

\begin{tabular}{lccccc}
\hline & & EM-2 & peptide-1 & peptide-2 & peptide-3 \\
\hline $\begin{array}{l}\text { inhibitory } \\
\text { constants } \\
(\mathrm{nM})\end{array}$ & $K_{\mathrm{i}}^{\mu}$ & $1.3 \pm 0.2$ & $0.2 \pm 0.08$ & $2.4 \pm 0.1$ & $2.4 \pm 0.1$ \\
$\begin{array}{l}\text { selectivity } \\
\left(\mathrm{K}_{\mathrm{i}}^{\delta} / \mathrm{K}_{\mathrm{i}}{ }^{\mu}\right)\end{array}$ & $K_{\mathrm{i}}^{\delta}$ & $5652 \pm 202$ & $93.6 \pm 16$ & $>10000$ & $812 \pm 18$ \\
$\mathrm{MS}$ & {$[\mathrm{M}]_{\text {cal. }}$} & 571 & 456 & 1999 & 338 \\
$\mathrm{MS}$ & {$[\mathrm{M}+\mathrm{H}]^{+}$} & 572.3 & 599 & 585 & 599 \\
half-life $(\mathrm{min})$ & & $3.08 \pm 0.2$ & $39.6 \pm 5.6$ & $>720$ & $>720$ \\
reference & 558 & 59 & 58 & 58 \\
Log $P$ & & $0.457 \pm 0.05$ & $1.183 \pm 0.03$ & $0.696 \pm 0.03$ & $0.925 \pm 0.04$ \\
\hline
\end{tabular}

$\left[{ }^{3} \mathrm{H}\right]$ DAMGO $\left(\mathrm{K}_{\mathrm{d}}=0.5 \mathrm{nM}\right)$ was used as a radioligand for the $\mu$-opioid receptor. $\left[{ }^{3} \mathrm{H}\right]$ Ile ${ }^{5,6}$-deltorphin-2 $\left(\mathrm{K}_{\mathrm{d}}\right.$ $=2.0 \mathrm{nM}$ ) was used as a radioligand for the $\delta$-opioid receptor. $K_{\mathrm{i}}$ values were calculated according to the Cheng-Prusoff equation: $\mathrm{K}_{\mathrm{i}}=\mathrm{EC}_{50} /\left(1+[\right.$ Ligand $\left.] / \mathrm{K}_{\mathrm{d}}\right)$. Data are expressed as means $\pm \mathrm{SEM}, \mathrm{n} \geq 3$. Inhibitory constants, half-life, mass spectrometry data was taken from references. 


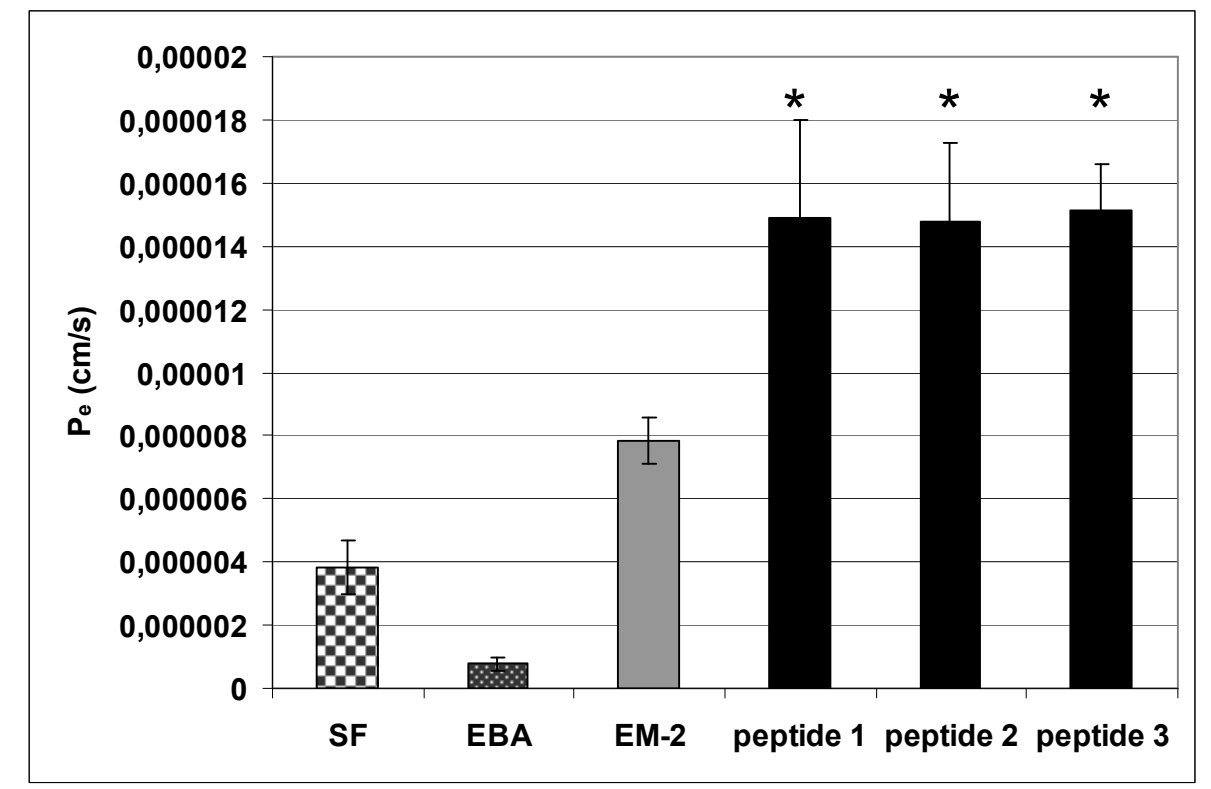

Figure 6. Permeability coefficient $\left(P_{e}\right)$ of the peptides. The $P_{e}$ of peptide 1, 2 and 3 was calculated and compared to the permeability of EM-2. As a control the $P_{e}$ of sodium fluorescein (SF) and Evans blue labeled albumin (EBA) was also calculated. Data are presented as means \pm SEM. ${ }^{*}=P<0.05$ as assessed by ANOVA and Bonferroni's post hoc test (compared to EM-2).

\subsection{In vivo characterization of most potent EM-2 analogues}

As regards to the in vivo antinociceptive effect of endomorphin derivatives, several studies investigated the effects of the ligands after systemic or intracerebroventricular (i.c.v.) administration, while only a few studies are available about the effects of the derivatives at the spinal level. Based on the binding potencies, compounds 10, 12, 14, and 16 were selected to investigate the anti-allodynic effects at spinal level in the chronic joint pain model. In vivo studies were performed in collaboration with Dr. Gyöngyi Horváth, Department of Physiology, Faculty of Medicine, University of Szeged, Szeged, Hungary. All of the analogues elicited an 
antinociceptive effect in a concentration dependent manner. At low doses $(0.1 \mu \mathrm{g})$, compounds 12 and 16 produced a significant antinociception, while EM-2 and the other two ligands were ineffective at this dose. Compounds 12 and $\mathbf{1 6}$ produced a prolonged antinociception at a $0.3 \mu \mathrm{g}$ dose while the other ligands were ineffective. In the case of 3 $\mu \mathrm{g}$, all of the ligands produced anti-allodynia. Regarding the highest dose, $10 \mu \mathrm{g}$ of compound 16 caused a prolonged paralysis of the animals, therefore, data was not analyzed in the pain test. Morphine, as a positive control, produced long-lasting highly effective antinociception. EM-2, compounds 10 and $\mathbf{1 4}$ were as effective as morphine for 10-30 $\mathrm{min}$, while the effect of compounds $\mathbf{1 2}$ did not differ significantly from morphine during the whole period (75-120 $\mathrm{min})$. These results were summarized and submitted to Acta Physiologica Hungarica journal [134].

\subsection{Tritiated neuropeptides}

Over the decades tritium labeled bioactive peptides have been used as valuable tools for biological characterization of receptors, and binding sites. The metabolic pathway of tritium labeled compounds is also easily traceable. We are aiming to synthesize biologically active peptides in tritiated form by synthesizing the respective precursor peptide followed by tritiation to acquire suitable tools for use in in vitro and in vivo biological assays. Several bio-active ligands were tritiated in our laboratory for the past three years to apply them in different biochemical assays. Tritium labeled ligands are very useful in finding the biosynthetic pathways of precursor proteins.

The biosynthetic pathways of other opioid peptides have already been clarified (it happens through a single- or multi-step cleavage from large molecular weight precursor proteins with or without additional post-translational modifications), but the biosynthetic route of endomorphins is still obscure. Recent findings suggested that EM-2 may be produced from a human sulfate transporter protein in consecutive enzymatic reactions [135]. Many biologically active neuropeptides and peptide hormones were shown to be synthesized from inactive glycine-extended precursors, which require a carboxy-terminal 
posttranslational amidation for biological activity [135]. This reaction is catalyzed by a consecutive action of peptidylglycine- $\alpha$-hydroxylating monooxygenase (PHM) and peptidylamidoglycolate lyase (PAL). These two enzymes are part of the peptidylglycine $\alpha$-amidating monooxygenase (PAM), a bifunctional, integral membrane-bound enzyme machinery [136]. In attempt to elicit the hypothesis that EM-2 may be produced from the sulfate transporter precursor protein by the activation of the PAM enzyme system, we designed and synthesized a novel peptide Gly ${ }^{5}$-extended EM-2 and labeled it with tritium. Tritiated Gly ${ }^{5}-\mathrm{EM}-2$ is being tested in rat brain membrane homogenate. We are still awaiting the results.

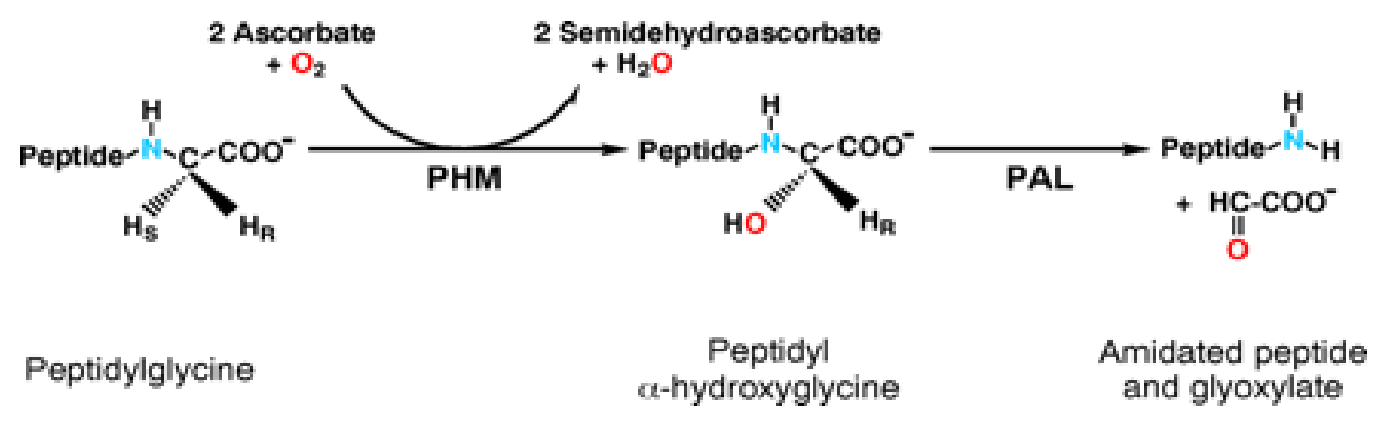

Figure 7. Reaction catalyzed by bifunctional PAM. The PHM domain catalyzes the oxygen- and ascorbate-dependent hydroxylation of peptidylglycine, forming the $\alpha$ hydroxyglycine intermediate. The PAL domain cleaves the intermediate and releases amidated peptide and glyoxylate. Colored atoms indicate that molecular oxygen is incorporated into $\alpha$-hydroxyglycine, and that the product amide nitrogen is derived from the substrate glycine.

Cumulated data on EM-2 and its analogues and other tritiated neuropeptides was summerized and published recently in Arkivoc journal [137]. The following bioactive neuropeptides were tritiated in our laboratory to use in various pharmacological characterizations. Specific activities of tritiated compounds are listed in Table 8. 


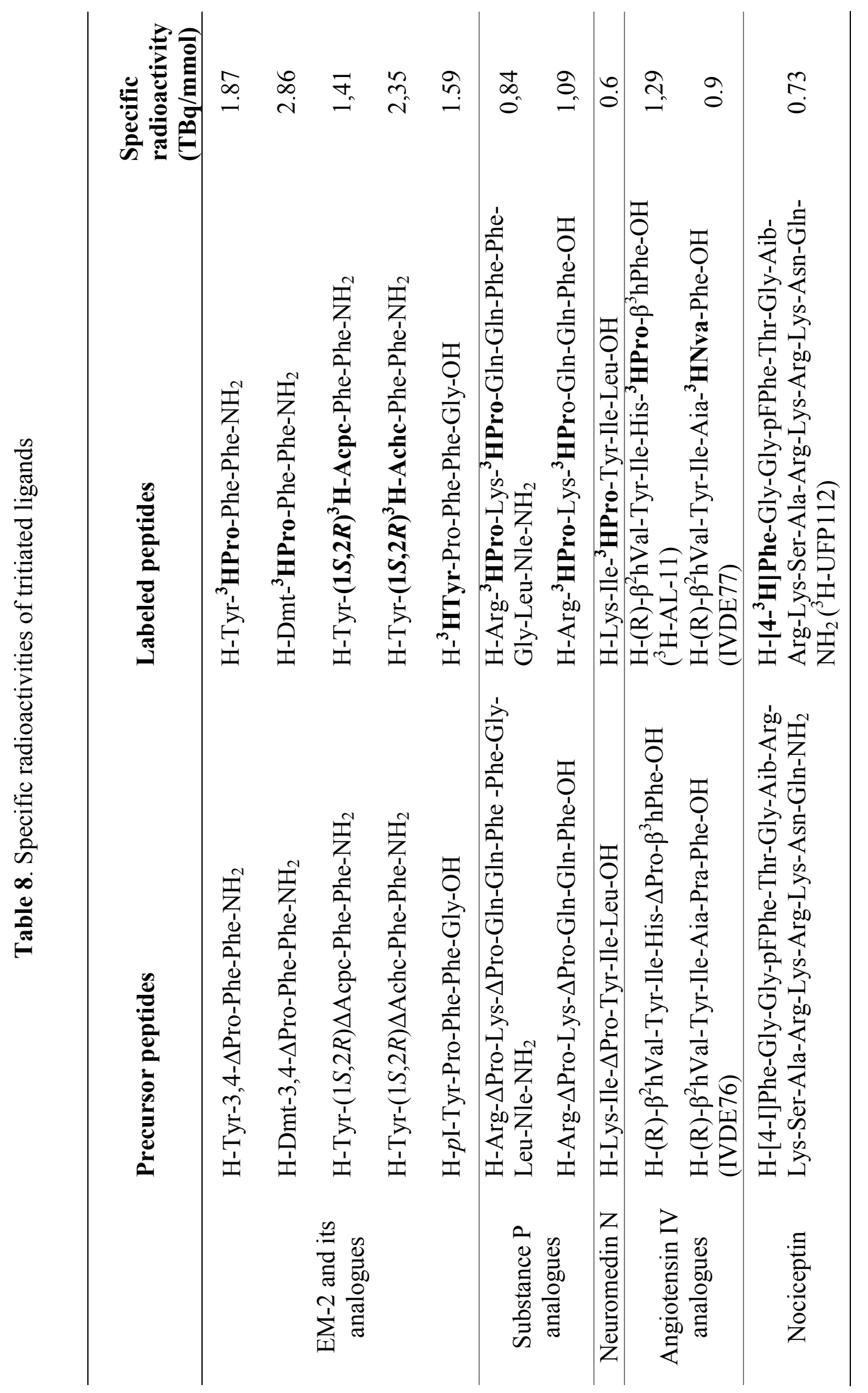




\section{Discussion}

In the structure of endomorphins three aromatic amino acid residues, which play a crucial role in the recognition of the opioid receptors, are connected by a $\mathrm{Pro}^{2}$ residue. This residue is considered a spacer, stabilizing the bioactive conformation of the endomorphins $[19,58]$. The extensively investigated cis-trans isomerization around the $\mathrm{Tyr}^{1}-\mathrm{Pro}^{2}$ peptide backbone permits the endomorphins to adopt many accessible conformations, making the determination of bioactive conformation(s) and the mode of ligand binding difficult [48]. The backbone and side-chain conformations of the $\mu$-opioid receptor ligands contribute concomitantly to the orientation of the pharmacophore groups. To reveal the precise structural orientations and interactions between the $\mu$-opioid receptor and endomorphins, numerous analogues needed to be synthesized. In the present study, unnatural amino acids were introduced into different positions of endomorphins in order to obtain proteolytically stable compounds for the study of the bioactive structure(s), favorable for opioid binding. To obtain the desired analogues, $\mathrm{Dmt}^{1}$, constrained alicyclic $\beta$-amino acids in the place of $\mathrm{Pro}^{2}$, side chain constrained $\beta \mathrm{MePhe}^{4}$ and $\mathrm{pFPhe}^{4}$ in the position of $\mathrm{Phe}^{4}$ were inserted. Dmt substitution of the $\mathrm{Tyr}^{1}$ residue yielded potent agonist analogues with high affinities and various selectivities [53, 59, 138 and 139]. The observed variabilities in biological properties may be due to interactions between $\mathrm{Dmt}^{1}$ and the remaining structural elements: the $\mathrm{Tyr}^{1}-\mathrm{Pro}^{2}$ and aromaticaromatic interactions $\left(\mathrm{Tyr}^{1} / \mathrm{Dmt}^{1}-\mathrm{Trp}^{3},-\mathrm{Phe}^{3},-\mathrm{Phe}^{4}\right)$. They were found to be involved in stabilizing the local conformations of endomorphins [82]. Furthermore, inserted methyl groups cause decreased acidity of the phenolic hydroxyl group, accordingly optimizing the hydrophobic and steric interactions of the analogues with the opioid receptors [58]. Consequently, the substituted analogues retain their affinities for the $\mu$-opioid receptors, though they suffer a remarkable loss in selectivity.

Incorporation of Dmt, racemic cis- alicyclic $\beta$-amino acids, Hyp, $\beta$ Pro, side chain restricted $\beta$ MePhe and $\mathrm{pFPhe}$ yielded a series of peptide analogues with altered proteolytic stabilities and pharmacological activities. Compounds with $(1 S, 2 R)-\beta$-amino acid configuration were found to be more potent than those of the $(1 R, 2 S)$ configuration. 
Substitution with para-halogenated amino acids [among all halogenated $(\mathrm{F}, \mathrm{Cl}, \mathrm{Br}$ and $\mathrm{I})$ $\mathrm{Phe}^{4}$ residues] $\mathrm{pFPhe}^{4}$ residue containing EM-1 and -2 derivatives showed an increased affinities for $\mu$-opioid receptor $\left(K_{\mathrm{i}}=1.2 \mathrm{nM}\right.$ and $3.4 \mathrm{nM}$ for pFPhe ${ }^{4}$-EM- 1 and $\mathrm{pFPhe}{ }^{4}-$ EM-2 respectively) in receptor binding assays compared to other halogenated analogues. Endomorphins with pClPhe ${ }^{4}$ displayed $K_{\mathrm{i}}$ values for $\mu$-opioid receptor $3.3 \mathrm{nM}$ and 7.4 $\mathrm{nM}$ for EM-1 and -2 respectively. Analogues with $\mathrm{pBrPhe}{ }^{4}$ showed $K_{\mathrm{i}}$ values with $11 \mathrm{nM}$ and $13 \mathrm{nM}$ for EM-1 and -2 respectively, for the $\mu$-opioid receptor. pIPhe ${ }^{4}$ containing analogues exhibited $K_{\mathrm{i}}$ values with $11 \mathrm{nM}$ and $39 \mathrm{nM}$ for EM-1 and EM-2 respectively, for the $\mu$-opioid receptor. All of the halogenated analogues resulted in decreased selectivities [67]. The present findings confirmed the selectivity of halogenated amino acids in the place of $\mathrm{Phe}^{4}$ to design biologically active endomorphins. Incorporation of $(2 S, 3 S) \beta \mathrm{MePhe}$ resulted in analogues with increased affinity and potency as compared with the parent ligands, while $(2 R, 3 R) \beta \mathrm{MePhe}$ substitution decreased the affinity and selectivity toward the $\mu$-opioid receptor. These results confirm that the modulation of side chain rotations is a very important feature in determining the biological activity of a peptide. These results further confirmed the importance of chirality in binding to the receptor $[58,68]$. Insertion of $(Z)-\alpha, \beta$-didehydrophenylalanine ([ $\left.\Delta^{\mathrm{Z} P h e}\right]-\mathrm{EM}-2$ in the position of $\mathrm{Phe}^{3}, \mathrm{Phe}^{4}$ in EM-2 resulted in a different binding affinity profile. The $\left[\Delta^{z} \mathrm{Phe}{ }^{4}\right]$-EM-2 exhibited higher $\mu$-receptor affinity $\left(K_{\mathrm{i}}=8.4 \mathrm{nM}\right)$ and selectivity $\left(K_{\mathrm{i}}^{\delta / \mu}=\right.$ $>1200)$ than that of the $\left[\Delta^{Z} \mathrm{Phe}^{3}\right]-\mathrm{EM}-2\left(K_{\mathrm{i}}=200 \mathrm{nM}\right)[140]$. Similar results were observed for substitutions with $\beta \mathrm{MePhe}$ in the place of $\mathrm{Phe}^{3}, \mathrm{Phe}^{4}$ in EM-2 which further confirmed the significance of $\mathrm{Phe}^{3}$ in endomorphins [141]. Morphiceptin (H-Tyr-ProPhe-Pro- $\mathrm{NH}_{2}$ ), another $\mu$-opioid receptor-selective agonist with identical N-terminal message sequence to endomorphins, provided important clues regarding its binding activity and specificity [87]. The insertion of diastereomric $\beta \mathrm{Pro}^{2}$ in morphiceptin yielded analogues with different biological activity profile. In contrast with the present results, $(R)-\beta \operatorname{Pro}^{2}$ had higher $\mu$-opioid receptor affinity $\left(K_{\mathrm{i}}=58 \mathrm{nM}\right)$ than the other isomer $(S)$ $\beta \operatorname{Pro}^{2}\left(K_{\mathrm{i}}=293 \mathrm{nM}\right)$, both analogues were inactive at the $\delta$-opioid receptor [87]. These results confirm that each class of opioid peptides shows distinct chiral requirements for the spacers between the biologically important Tyr and Phe residues [47]. Introduction of a polar -OH group on the $\mathrm{Pro}^{2}$ side chain and the extension of the backbone by a $-\mathrm{CH}_{2}$ - 
group, while preserving the tertiary amide moiety of Pro has disadvantageous effects on $\mu$-opioid receptor activity of EM-2 in general, regardless of different experimental conditions [142]. However, the observed effect of $\beta$ Pro $^{2}$ substitution may not be applicable generally for all $\mu$-opioid receptor ligands, since in a previous study $\beta$ Pro-EM1 exhibited $\mu$-opioid receptor affinity, efficacy and agonist behavior similar to those of DAMGO and EM-1 [130]. This indicates that the incorporation of a $-\mathrm{CH}_{2}$ - group between the pyrrolidine ring and the carboxyl group of the second residue of the endomorphin sequence may affect receptor-ligand interactions differently when the following amino acid residue is Trp or Phe. Furthermore, diastereomeric $\beta \mathrm{Pro}^{2}$ substitution in morphiceptin yielded analogues with different biological activity profile, $(R)-\beta \operatorname{Pro}^{2}-$ morphiceptin had higher $\mu$-opioid receptor affinity than $(S)$ - $\beta$ Pro $^{2}$-morphiceptin [87]. This suggests that in certain cases $\mu$-opioid receptor ligands may have distinct chiral requirements for the spacers between the biologically important Tyr and Phe residues. In endomorphin analogues containing unsaturated alicyclic $\beta$-amino acids the $1 S, 2 R$ side chain configuration was shown to furnish $\mu$-opioid receptor activity exclusively.

The ligand stimulated $\left[{ }^{35} \mathrm{~S}\right] \mathrm{GTP} \gamma \mathrm{S}$ binding assay is a common pharmacological probe that is widely used to determine functional properties of receptor ligands. As this assay measures the level of G-protein activation following agonist occupation of the binding site, its advantage is that it follows the direct functional consequences of receptor occupancy, independently of the downstream-effector systems [143, 144]. In a pool of analogues, most of the endomorphin derivatives exhibited higher efficacies than those of the parent compounds. Based on the $\left[{ }^{35} \mathrm{~S}\right] \mathrm{GTP} \gamma \mathrm{S}$ binding assay results, all examined endomorphin analogues retained partial agonist properties, similar to those of the endomorphins. Insertion of alicyclic $\beta$-amino acid itself did not alter the agonist/antagonist properties in both endomorphins [58]. The co-application of Dmt, alicyclic $\beta$-amino acid (cis-(1S,2R)Achc) and pFPhe resulted in a highly potent analogue. The observed efficacy for compound $16\left(E_{\max }=176 \%\right)$ was comparable with the universal $\mu$-receptor agonist DAMGO $\left(E_{\max }=178 \%\right)$. The results of the $\left[{ }^{35} \mathrm{~S}\right] \mathrm{GTP} \gamma \mathrm{S}$ binding experiments in the presence of the general antagonist naloxone showed that the ligands bind to opioid receptors, activate G-proteins and presumably downstream signaling. It is 
interesting to note that compounds 4, 12 and $\mathbf{1 6}$ stimulated G-protein binding even in the presence of $10^{-5} \mathrm{M}$ naloxone (data not shown) therefore, we hypothesized that these ligands may also bind to other G-protein coupled receptors or to non-opioid binding sites.

Highly potent analogues were selected based on receptor binding and $\left[{ }^{35} \mathrm{~S}\right] \mathrm{GTP} \gamma \mathrm{S}$ binding assays to perform metabolic stability studies of the newly synthesized analogues against proteolytic degrading enzymes. Analogues containing $\mathrm{Hyp}^{2}$ and $\beta_{\mathrm{Pro}}^{2}$ had increased 3- and 6 fold higher stabilities, respectively in comparison with the parent compound EM-2. In consistence with earlier results [58, 79], analogues with alicyclic $\beta$ amino acids have shown prolonged half-lives ( $>20 \mathrm{~h})$ compared to parent endomorphins $\left(\mathrm{t}_{1 / 2}=5-7 \mathrm{~min}\right)$. These results confirmed that Pro $^{2}$ targeting modifications result in proteolytically stable peptides.

${ }^{1} \mathrm{H}-\mathrm{NMR}$ studies on $\mathrm{Dmt}^{1}$ substituted endomorphins showed higher cis conformation (cis/trans ratio 2:1) [59], this conformational differing from that calculated for parent compounds (higher trans ratio) were based on molecular modeling studies [81]. When the results are taken into account, a reduction of binding potency can be expected, but both analogues displayed comparable binding to endomorphins in rat brain membrane preparations [59]. Thereby, the interpretation of ${ }^{1} \mathrm{H}-\mathrm{NMR}$ and molecular modeling data demands caution. To control the cis/trans isomerization around the $\mathrm{Tyr}^{1}$ $\mathrm{Pro}^{2}$ peptide backbone, alicyclic $\beta$-amino acids were inserted in the place of $\operatorname{Pro}^{2}$. The incorporation of racemic alicyclic $\beta$-amino acids resulted in analogues with altered biological activities depending on chirality of amino acid [58, 79]. Previous studies on substitution of $\operatorname{Pro}^{2}$ by $(1 S, 2 R) \mathrm{Acpc}^{2}$ in endomorphins were shown to adopt bent structure more readily than $(1 R, 2 S)$-Acpc-containing analogues [58]. In consistence with previous findings, ${ }^{1} \mathrm{H}-\mathrm{NMR}$ and molecular modeling studies on highly potent analogues have shown a higher tendency to form a bent structure, suggesting turn structure for $\mu$-opioid receptor binding. In addition to this, various classic and non-canonical turn structures were identified as possible conformations of the analogues studied by the analysis of specific intramolecular H-bonds. The identified conformations provide advantageous orientation of the pharmacophore groups resulting in high-affinity binding to the $\mu$-opioid 
receptor [81]. Several unique structural elements were identified as the consequence of the elongation of the peptide backbone by incorporation of a $\beta$-amino acid. As biological data suggests, this elongation does not significantly affect the folding of these peptides or the orientation of the pharmacophore elements, confirming the role of $\operatorname{Pro}^{2}$ as a stereochemical spacer [79]. This is in accordance with previous findings on morphiceptin analogues with constrained topologies, where several unique structural elements were found as consequences of elongation of the peptide chain due to application of alicyclic $\beta$-amino acids [70]. Most of the special, non-canonical secondary structural elements were found to be stabilized by intramolecular H-bonds. In addition, aromatic-aromatic and proline-aromatic interactions may also play a significant role in the stabilization of such structures $[81,145]$.

The combined analysis of the competitive receptor binding assay, $\left[{ }^{35} \mathrm{~S}\right] \mathrm{GTP} \gamma \mathrm{S}$ binding assay and ${ }^{1} \mathrm{H}$-NMR studies and molecular dynamics simulations suggest that the receptor-ligand interactions are regulated by diverse structural aspects after the introduction of unnatural amino acids. Variability of the binding affinities and selectivities of the ligands could be explained, with the assumption that upon ligand binding to the receptor it might generate different affinity states in opioid receptors by either the cis or trans isomers of the opioid ligands. Since the receptors reportedly exist in different local conformational states, ligands with either a cis or a trans conformation are capable of coupling to the receptors, but with distinct affinities and selectivities, depending upon their structural features [88, 90 and 146]. In addition to this, it can't be excluded that ligands may bind to different subtypes of the $\mu$-receptor, i.e. hypothetical $\mu_{1}$ - and $\mu_{2}$ - receptors [147] which might be distinct proteins, or different binding proteins of the same protein. Although such distinction still waits in the case of $\mu$-receptor, the results of the present study describing the synthesis and binding characteristics of endomorphin analogues contribute in understanding structural and topographical requirements of peptide ligand binding.

Several endomorphin and neuropeptide analogues were tritiated in our laboratory to use as a tool in different biochemical assays such as in vitro radioligand receptor 
binding assays, radioimmunoassays. The advantage of tritium labeled radioactive peptides is that the structure of the radioactive material is the same as the parent peptide, so the biological activity is identical. Tritiated ligands are used in finding biosynthetic pathways of precursor proteins; in homologue or heterologue displacement studies to characterize the new derivatives.

Although endomorphins are very potent and highly selective $\mu$-opioid receptor agonists, their systemic administration for the clinical treatment of pain is impeded by their rapid degradation and limited delivery to the CNS. Promising structural modifications of both EM-1 and EM-2 have already been described [52, 53, 58, 59 and 62]. In these studies an improved antinociception was observed following peripheral administration of the peptide, which may be attributed to improved brain delivery, increased resistance against degradation or both. Evaluated EM-2 analogues [Dmt-ProPhe-Phe- $\mathrm{NH}_{2}$, Tyr-( $(1 S, 2 R)$ Acpc-Phe-Phe- $\mathrm{NH}_{2}$, Tyr- $(1 S, 2 R)$ Achc-Phe-Phe- $\left.\mathrm{NH}_{2}\right]$ showed relatively low, but improved BBB permeability properties compared to the parent compound EM-2. None of the peptides had a cytotoxic effect on the viability of brain endothelial cells. Accumulating the results of BBB permeabilities, antinociceptive effect and their enhanced enzymatic resistance, these peptides will have better analgesic properties in vivo and can lead to the development of successful opioid drugs.

A series of analogues, containing non-cyclic amino acids (Ala, D-Ala, $\beta$-Ala, Nmethylalanine: NMeAla, D-NMeAla or N-methylglycine) instead of Pro in position 2 were synthesized to assess the analgesic properties of endomorphins [148]. In the in vivo test applied in mice (HP test, i.c.v. administration) D-Ala ${ }^{2}$ EM-2 and D-NMeAla ${ }^{2}-\mathrm{EM}-2$ showed much higher analgesic potency than EM-2 which confirmed the usefulness of structural modifications in obtaining new leads for pain-relief therapeutics. EM-2 cyclic asparagine analogues (H-Tyr-cAsp[CHPh]-Phe-Phe- $\mathrm{NH}_{2}$ and $\mathrm{H}-\mathrm{Tyr}-\mathbf{c} \mathrm{Asp}\left[\mathrm{CHMe}_{2}\right]-\mathrm{Phe}-$ Phe- $\mathrm{NH}_{2}$ ) were investigated in acid-induced writhing test in mice after systemic (i.p.) administration [149]. H-Tyr-cAsp (CHPh)-Phe-Phe- $\mathrm{NH}_{2}$ had a higher potency compared to the parent drug, while H-Tyr-cAsp $\left(\mathrm{CHMe}_{2}\right)-\mathrm{Phe}-\mathrm{Phe}-\mathrm{NH}_{2}$ had a lower potency. Endomorphin analogues with six-membered heterocyclic rings (Tyr-[R]-Nip-Phe-Phe- 
$\mathrm{NH}_{2}$; Dmt-Nip-Phe-Phe-NH $\mathrm{NH}_{2}$; [Nip: piperidine-3-carboxylic acid]) were investigated in HP in mice, after i.c.v. administration [150]. These ligands produced a profound, longlasting supraspinal analgesia, being much more potent than EM-2. An earlier study showed that dimethyl-analogue of EM-2 (Dmt-EM-2) produced antinociception after i.t. injection in formalin test (rat) [151]. Among the tested analogues compounds $\mathbf{1 0}$ and $\mathbf{1 4}$ had similar effects than EM-2, and this is in agreement with their $K_{\mathrm{i}}$ values for the $\mu$ opioid receptor too. Compounds $\mathbf{1 2}$ and $\mathbf{1 6}$ showed high affinity to the $\mu$-opioid receptor and these ligands also had a long half-life in crude rat brain membrane homogenate. Therefore, the activation of the $\mu$-opioid receptor and their high metabolic stability could have led to prolonged antinociception. The results demonstrate that complex modification of endomorphins by introduction of Dmt, alicyclic $\beta$-amino acids, $\beta$ MePhe, and $\mathrm{pFPhe}$ into different position in EM-2 might be a promising strategy to enhance bioavailability of the peptides and may serve a role in the development of novel endomorphin analogues with increased therapeutic potential. Further studies are required to reveal the possible side effects of these ligands. 


\section{Summary of findings}

- A small pool of endomorphin analogues were synthesized by systematic incorporation of unnatural amino acids, such as $\mathrm{Dmt}^{1}, \mathrm{Achc}^{2}, \Delta \mathrm{Acpc}^{2} / \Delta \mathrm{Achc}^{2}$, $\mathrm{Hyp}^{2}, \beta \mathrm{Pro}^{2}, \beta \mathrm{MePhe}^{4}$ and $\mathrm{pFPhe}^{4}$. Such modifications yielded the analogues with increased proteolytic stability while retaining or enhancing the biological activity.

- Radioligand receptor-binding studies of newly synthesized analogues revealed that insertion of these amino acids resulted in moderate to highly potent compounds depending on the chiralities of the incorporated amino acids. The multiple modifications yielded the analogues with increased $\mu$-receptor affinities, but with decreased selectivities.

- The ligand-stimulated $\left[{ }^{35} \mathrm{~S}\right] \mathrm{GTP} \gamma \mathrm{S}$ binding assay results revealed that some of the analogues showed higher efficacies than the parent endomorphins. Most of the compounds retained agonist or partial agonist properties.

- Combined application of $\mathrm{Dmt}^{1}$, cis-( $(1 S, 2 R) \mathrm{Achc}^{2}$ and $\mathrm{pFPhe}^{4}$ resulted in the most potent analogue with a 1 order of magnitude higher receptor affinity compared to the parent compound EM-2. Furthermore, it displayed the highest efficacy in the ligand-stimulated $\left[{ }^{35} \mathrm{~S}\right] \mathrm{GTP} \gamma \mathrm{S}$ binding assay, acting as a full agonist.

- Findings of this study revealed that unsaturation of alicyclic $\beta$-amino acids had no effect on binding affinities of EM-2 in comparison with saturated alicyclic $\beta$ amino acids.

- The compound bearing $c i s-(1 S, 2 R) \Delta \mathrm{Acpc}^{2}$ displayed an equal $\mu$-opioid receptor affinity with high selectivity compared to the parent compound EM-2. 
- $\mathrm{Dmt}^{1},(1 S, 2 R) \mathrm{Acpc}^{2}$, and $(1 S, 2 R) \mathrm{Achc}^{2}$ containing EM-2 analogues have displayed higher blood-brain barrier permeabilities in comparison with the parent ligand with no viability of endothelial cells. None of the tested ligands had a cytotoxic effect on viability of rat brain endothelial cells.

- All of the tested ligands elicited an antinociceptive effect in a concentration dependent manner. Dmt- $(1 S, 2 R)$ Achc-Phe- $(2 S, 3 S) \beta \mathrm{MePhe}-\mathrm{NH}_{2}$ elicited antinociception comparable with morphine. 


\section{Acknowledgements}

I am sincerely thankful to my supervisor Dr. Géza Tóth for providing a great research opportunity in his lab. I greatly acknowledge his invaluable guidance and encouragement. Not only was he helpful in the thesis project but also in my future academic carrier.

I wish to thank Dr. Ferenc Fülöp and his lab members for synthesizing and providing alicyclic $\beta$-amino acids, in this thesis most of the work is associated with these amino acids.

I would like to thank Dr. Attila Keresztes for his help in performing the biological assays. I am also grateful to Dr. Attila Borics for his scientific advices and assistance in the evaluation of molecular modeling results; also I am thankful to Dr. Katalin Köver for measuring and analyzing ${ }^{1} \mathrm{H}-\mathrm{NMR}$ results.

I greatly acknowledge my collaborators Dr. István Krizbai and his group members for the in vitro blood-brain-barrier studies, Dr. Gyöngyi Horváth and her colleagues for in vivo characterization of the novel ligands.

I also acknowledge Dr. Zoltán Szabó and the staff of the MS laboratory in Institute of Biochemistry, Biological Research Center, Szeged, Hungary for the high resolution mass spectrometry.

I would like to express my gratitude to all my group members for their help and for the friendly atmosphere in the laboratory. I also wish to thank Dr. Fanni Tóth for rectifying the thesis. 
I gratefully thank the Institute of Biochemistry, Biological Research Centre, Hungarian Academy of Sciences, and Foundation for Hungarian Peptide and Protein Society for providing financial support for my $\mathrm{Ph} . \mathrm{D}$ studies, European grant "Normolife"(LSHC-CT-2006-037733) for my research funding.

I would also like to thank my nephew Pradeep Kumar Reddy Cingaram, for his inconspicuous support throughout my higher education. I am also very thankful to the ITC community, in particularly to the little Indian community in Szeged for their support, and making my stay in Hungary even more memorable.

Finally, I am very grateful to my family members for their support and endless love, which has been the greatest encouragement for my success. I wish to say a special thanks to my brother Narasimha Reddy Mallareddy for his invaluable support in each step of my life. 


\section{References}

[1] Beckett, A. H.; Casy, A. F. Synthetic analgesics: stereochemical considerations. $J$. Pharm. Pharmacol. 1954, 6, 986-999.

[2] Pierce, K. L.; Premont, R. T. \& Lefkowitz, R. J. Seven transmembrane receptors. Nature Rev. Mol. Cell Biol. 2002, 3, 639-650.

[3] Janecka, A.; Kruszynski, R. Conformationally restricted peptides as tools in opioid receptor studies. Curr. Med. Chem. 2005, 12, 471-481.

[4] Chen, Y.; Mestek, A.; Liu, J.; Yu, L. Molecular cloning of a rat kappa opioid receptor reveals sequence similarities to the mu and delta opioid receptors. Biochem J. 1993, 295, 625-628.

[5] Kieffer, B. L. Recent advances in molecular recognition and signal transduction of active peptides: receptors for opioid peptides. Cell Mol. Neurobiol. 1995, 15, 615-635.

[6] Chen, Y.; Mestek, A.; Liu, J.; Hurley, J. A.; Yu, L. Molecular cloning and functional expression of a $\mu$-opioid receptor from rat brain. Mol. Pharmacol. 1993, $44,8-12$.

[7] Mansour, A.; Khachaturian, H.; Lewis, M. E.; Akil, H.; Watson, S. J. Autoradiographic differentiation of mu, delta, and kappa opioid receptors in the rat forebrain and midbrain. J. Neurosci. 1987, 7, 2445-2464.

[8] Hawkins, K. N.; Knapp, R. J.; Gehlert, D. R.; Lui, G. K.; Yamamura, M. S.; Roeske, L. C.; Hruby, V. J.; Yamamura, H. I. Quantitative autoradiography of $\left[{ }^{3} \mathrm{H}\right]$ CTOP binding to $\mu$ opioid receptors in rat brain. Life Sci. 1988, 42, 25412551.

[9] Horvath, G. Endomorphin-1 and endomorphin-2: pharmacology of the selective endogenous $\mu$-opioid receptor agonists. Pharmacol. Ther. 2000, 88, 437-463.

[10] Fichna, J.; Janecka, A.; Piestrzeniewicz, M.; Costentin, J.; do-Rego, J. C. Antidepressant-like effect of endomorphin-1 and endomorphin-2 in mice. Neuropsychopharmacology. 2007, 32, 813-821.

[11] Chevlen, E. Opioids: a review. Curr. Pain Headache Rep. 2003, 7, 15-23. 
[12] Kosterlitz, H. W.; Paterson, S. J. Types of opioid receptors: relation to antinociception. Philos. Trans. R. Soc. Lond. B. Biol. Sci. 1985, 308, 291-297.

[13] Hughes, J.; Smith, T. W.; Kosterlitz, H. W.; Fothergill, L. A.; Morgan, G. A.; Morris H. R. Identification of two related pentapeptides from the brain with potent opiate agonist activity. Nature. 1975, 258, 577-580.

[14] Chavkin, C.; James, I. F.; Goldstein, A. Dynorphin is a specific endogenous ligand of the $\kappa$ opioid receptor. Science. 1982, 215, 413-415.

[15] Nakanishi, S.; Inoue, A.; Kita, T.; Nakamura, M.; Chang, A. C.; Cohen, S. N.; Numa, S. Nucleotide sequence of cloned cDNA for bovine corticotropin-beta lipotropin precursor. Nature. 1979, 278, 423-427.

[16] Kakidani, H.; Furutani, Y.; Takahashi, H.; Noda, M.; Morimoto, Y.; Hirose, T.; Asai, M.; Inayama, S.; Nakanishi, S.; Numa, S. Cloning and sequence analysis of cDNA for porcine beta-neo-endorphin/dynorphin precursor. Nature. 1982, 298, 245-249.

[17] Meunier, J. C.; Mollereau, C.; Toll, L.; Suaudeau, C.;Moisand, C.; Alvinerie, P.; Butour, J. L.; Guillemot, J. C.; Ferrara, P.; Monsarrat, B.; Mazarguil, H.; Vassart, G.; Parmentier, M.; Costentin, J. Isolation and structure of the endogenous agonist of opioid receptor-like $\mathrm{ORL}_{1}$ receptor. Nature. 1995, 377, 532-535.

[18] Shenker, A. G protein-coupled receptor structure and function: the impact of disease-causing mutations. Baillieres Clin. Endocrinol. Metab. 1995, 9, 427-451.

[19] Brantl, V.; Gramsch, C.; Lottspeich, F.; Mertz, R.; Jaeger, K. H.; Herz, A. Novel opioid peptides derived from hemoglobin: hemorphins. Eur J Pharmacol. 1986, $125,309-310$.

[20] Zhao, Q; Garreau, I; Sannier, F.; Piot, J. M. Opioid peptides derived from hemoglobin: hermorphins. Biopolymers. 1997, 43, 75-98.

[21] Bozó, B.; Fülöp, F.; Tóth, G.; Szücs, M. Synthesis and opioid binding activity of dermorphin analogues containing cyclic $\beta$-amino acids. Neuropeptides. 1997, 31, 367-372.

[22] Zadina, J. E.; Hackler, L.; Ge, L. J.; Kastin, A. J. A potent and selective endogenous agonist for the $\mu$-opiate receptor. Nature. 1997, 386, 499-502. 
[23] Cheng, Y.; Prusoff, W. H. Relationship between the inhibition constant $\left(K_{\mathrm{i}}\right)$ and the concentration of inhibitor which causes 50 per cent inhibition (I50) of an enzymatic reaction. Biochem. Pharmacol. 1973, 22, 3099-3108.

[24] Amiche, M.; Delfour, A.; Nicolas, P. Opioid peptides from frog skin. EXS. 1998, $85,57-71$.

[25] Kreil, G.; Barra, D.; Simmaco, M.; Erspamer, V.; Erspamer, G. F.; Negri, L.; Severini, C.; Corsi, R.; Melchiorri, P. Deltorphin, a novel amphibian skin peptide with high selectivity and affinity for delta opioid receptors. Eur. J. Pharmacol. 1989, 162, 123-128.

[26] Corbett, A. D.; Henderson, G.; McKnight, A. T.; Paterson, S. J. 75 years of opioid research: the exciting but vain quest for the Holy Grail. Br. J. Pharmacol. 2006, 47, S153-S162.

[27] Quock, R. M.; Burkey, T. H.; Varga, E.; Hosohata, Y.; Hosohata, K.; Cowell, S. M.; Slate, C. A.; Ehlert, F. J.; Roeske, W. R.; Yamamura, H. I. The delta-opioid receptor: molecular pharmacology, signal transduction, and the determination of drug efficacy. Pharmacol. Rev. 1999, 51, 503-532.

[28] Henderson, G.; McKnight, A. T. The orphan opioid receptor and its endogenous ligand--nociceptin/orphanin FQ. Trends Pharmacol Sci. 1997, 18, 293-300.

[29] Wilhelm, I.; Fazakas, C.; Krizbai, I. A. In vitro models of the blood-brain barrier. Acta. Neurobiol. Exp. 2011, 71, 113-128.

[30] Jeffrey, P.; Summerfield, S. Assessment of the blood-brain barrier in CNS drug discovery. Neurobiol. Dis. 2010, 37, 33-37.

[31] Tömböly, C.; Péter, A.; Tóth, G. In vitro study of the degradation of endomorphins. Peptides. 2002, 23, 1573-1580.

[32] Hackler, L.; Zadina, J. E.; Ge, L. J.; Kastin, A. J. Isolation of relatively large amount of endomorphin-1 and endomorphin-2 from human brain cortex. Peptides. 1997, 18, 1635-1639.

[33] Rónai, A. Z.; Szemenyei, E.; Kató , E.; Kocsis, L.; Orosz, G.; Al-Khrasani, M.; Tóth, G. Endomorphin synthesis in rat brain from intracerebroventricularly injected $\left[{ }^{3} \mathrm{H}\right]-$ Tyr-Pro: a possible biosynthetic route for endomorphins. Regul. Pept. 2006, 134, 54-60. 
[34] Schreff, M.; Schulz, S.; Wiborny, D.; Höllt, V. Immunofluorescent identification of endomorphin-2-containing nerve fibers and terminals in the rat brain and spinal cord. Neuroreport. 1998, 9, 1031-1034.

[35] Martin-Schild, S.; Gerall, A. A.; Kastin, A. J.; Zadina, J. E. Differential distribution of endomorphin 1- and endomorphin 2-like immunoreactivities in the CNS of the rodent. J Comp Neurol. 1999, 405, 450-471.

[36] Pierce, T. L.; Wessendorf, M. W. Immunocytochemical mapping of endomorphin-2-immunoreactivity in rat brain. J. Chem. Neuroanat. 2000, 18, 181-207.

[37] Zadina, J. E.; Martin-Schild, S.; Gerall, A. A.; Kastin, A. J.; Hackler, L.; Ge, L. J.; Zhang, X. Endomorphins: novel endogenous mu-opiate receptor agonists in regions of high mu-opiate receptor density. Ann. N. Y. Acad. Sci. 1999, 897, 136144.

[38] Goldberg, I. E.; Rossi, G. C.; Letchworth, S. R.; Mathis, J. P.; Ryan-Moro. J.; Leventhal, L.; Su, W.; Emmel, D.; Bolan, E. A.; Pasternak, G. W. Pharmacological characterization of endomorphin-1 and endomorphin-2 in mouse brain. J. Pharmacol. Exp. Ther. 1998, 286, 1007-1013.

[39] Stone, L. S.; Fairbanks, C. A.; Laughlin, T. M.; Nguyen, H. O.; Bushy, T. M.; Wessendorf, M. W.; Wilcox, G. L. Spinal analgesic actions of the new endogenous opioid peptides endomorphin-1 and -2. Neuroreport. 1997, 8, 31313135.

[40] Horváth, G.; Szikszay, M.; Tömböly, C.; Benedek, G. Antinociceptive effects of intrathecal endomorphin-1 and -2 in rats. Life Sci. 1999, 65, 2635-2641.

[41] Sakurada, S.; Hayashi, T.; Yuhki, M.; Fujimura, T.; Murayama, K.; Yonezawa, A.; Sakurada, C.; Takeshita, M.; Zadina, J. E.; Kastin, A. J.; Sakurada T. Differential antagonism of endomorphin-1 and endomorphin-2 spinal antinociception by naloxonazine and 3-methoxynaltrexone. Brain Res. 2000, 881, $1-8$.

[42] Sakurada, S.; Zadina, J. E.; Kastin, A. J.; Katsuyama, S.; Fujimura, T.; Murayama, K, Yuki, M.; Ueda, H.; Sakurada, T. Differential involvement of mu- 
opioid receptor subtypes in endomorphin-1- and -2-induced antinociception. Eur. J. Pharmacol. 1999, 372, 25-30.

[43] Sakurada, S.; Hayashi, T.; Yuhki, M. Differential antinociceptive effects induced by intrathecally-administered endomorphin-1 and endomorphin-2 in mice. Jpn. J. Pharmacol. 2002, 89, 221-223.

[44] Ohsawa, M.; Mizoguchi, H.; Narita, M.; Nagase, H.; Kampine, J. P.; Tseng, L. F. Differential antinociception induced by spinally administered endomorphin-1 and endomorphin-2 in the mouse. J. Pharmacol. Exp. Ther. 2001, 298, 592-597.

[45] Grass, S.; Xu, I. S.; Wiesenfeld-Hallin, Z.; Xu, X. J. Comparison of the effect of intrathecal endomorphin-1 and endomorphin-2 on spinal cord excitability in rats. Neurosci. Lett. 2002, 324, 197-200.

[46] Vaccarino, A. L.; Olson, G. A.; Olson, R. D.; Kastin, A. J. Endogenous opiates: 1998. Peptides. 1999, 20, 1527-1574.

[47] Yamazaki, T.; Ro, S.; Goodman, M.; Chung, N. N.; Schiller, P. W. A topochemical approach to explain morphiceptin bioactivity. J. Med. Chem. 1993, 36, 708-719.

[48] Podlogar, B. L.; Paterlini, M. G.; Ferguson, D. M.; Leo, G. C.; Demeter, D. A.; Brown, F. K.; Reitz, A. B. Conformational analysis of the endogenous $\mu$-opioid agonist endomorphin-1 using NMR spectroscopy and molecular modeling. FEBS Lett. 1998, 439, 13-20.

[49] Gentilucci, L.; Tolomelli, A. Recent advances in the investigation of the bioactive conformation of peptides active at the $\mu$-opioid receptor. Conformational analysis of endomorphins. Curr. Top. Med. Chem. 2004, 4, 105-121.

[50] Mentlein, R. Dipeptidyl-peptidase IV (CD26)-role in the inactivation of regulatory peptides. Regul. Pept. 1999, 85, 9-24.

[51] Shane, R.; Wilk, S.; Bodnar, R. J. Modulation of endomorphin-2-induced analgesia by dipeptidyl peptidase IV. Brain Res. 1999, 815, 278-286.

[52] Okada, Y.; Fujita, Y.; Motoyama, T.; Tsuda, Y.; Yokoi, T.; Li, T.; Sasaki, Y.; Ambo, A.; Jinsmaa, Y.; Bryant, S. D.; Lazarus, L. H. Structural studies of [2', 6'Dimethyl-L-Tyrosine ${ }^{1}$ ] endomorphin-2 analogues: enhanced activity and cis 
orientation of the Dmt-Pro amide bond. Bioorg. Med. Chem. 2003, 11, 19831994.

[53] Bryant, S. D.; Jinsmaa, Y.; Salvadori, S.; Okada, Y.; Lazarus. L. H. Dmt and opioid peptides: a potent alliance. Biopolymers. 2003, 71, 86-102.

[54] Li, T.; Shiotani, K.; Miyazaki, A.; Tsuda, Y.; Ambo, A.; Sasaki, Y.; Jinsmaa, Y.; Marczak, E.; Bryant, S. D.; Lazarus, L. H.; Okada, Y. Bifunctional [2',6'Dimethyl-L-tyrosine ${ }^{1}$ ]Endomorphin-2 analogues substituted at position 3 with alkylated phenylalanine derivatives yield potent mixed $\mu$-Agonist $/ \delta$-Antagonist and dual $\mu$-/ $\delta$-agonist opioid ligands. J. Med. Chem. 2007, 50, 2753-2766.

[55] Harrison, B. A.; Pasternak, G. W.; Verdine, G. L. 2', 6'-Dimethyltyrosine analogues of a stereodiversified ligand library: highly potent, selective, nonpeptidic $\mu$ opioid receptor agonists. J. Med. Chem. 2003, 46, 677-680.

[56] Marczak, E. D.; Jinsmaa,Y.;Li, T.; Bryant, S. D.; Tsuda, Y.; Okada, Y.; Lazarus, L. H. [N-allyl-Dmt ${ }^{1}$-endomorphins are $\mu$-opioid receptor antagonists lacking inverse agonist properties. J. Pharmacol. Exp. Ther. 2007, 323, 374-380.

[57] Li, T.; Jinsmaa, Y.; Nedachi, M.; Miyazaki, A.; Tsuda, Y.; Ambo, A.; Sasaki, Y.; Bryant, S. D.; Marczak, E.; Li, Q.; Swartzwelder, H. S.; Lazarus, L. H.; Okada, Y. Transformation of $\mu$-opioid receptor agonists into biologically potent $\mu$-opioid receptor antagonists. Bioorg. Med. Chem. 2007, 15, 1237-1251.

[58] Keresztes, A.; Szücs, M.; Borics. A.; Kövér K. E.; Forró, E.; Fülöp, F.; Tömböly, C.; Péter, A.; Páhi, A.; Fábián, G.; Murányi, M.; Tóth, G. New endomorphin analogues containing alicyclic $\beta$-amino acids: Influence on bioactive conformation and pharmacological profile. J. Med. Chem. 2008, 51, 4270-4279.

[59] Tóth, G.; Keresztes, A.; Tömböly, Cs.; Péter, A.; Fülöp, F.; Tourwé, D.; Navratilova, E.; Varga, É.; Roeske, W. R.; Yamamura, H. I.; Szücs, M.; Borsodi, A.; New endomorphin analogs with $\mu$-agonist and $\delta$-antagonist properties. Pure Appl. Chem. 2004, 76, 951-957.

[60] Schiller, P. W.; Weltrowska, G.; Berezowska, I.; Nguyen, T. M.; Wilkes, B. C.; Lemieux, C.; Chung, N. N. The TIPP opioid peptide family: development of $\delta$ antagonists, $\delta$-agonists, and mixed $\mu$ - agonist/ $\delta$ - antagonists. Biopolymers. 1999, $51,411-425$. 
[61] Keller, M.; Boissard, C.; Patiny, L.; Chung, N. N.; Lemieux, C.; Mutter, M.; Schiller, P. W. Pseudoproline-containing analogues of morphiceptin and endomorphin-2: evidence for a cis Tyr-Pro amide bond in the bioactive conformation. J. Med. Chem. 2001, 44, 3896-3903.

[62] Staniszewska, R.; Fichna, J.; Gach, K.; Tóth, G.; Poels, J.; Vanden Broeck, J.; Janecka, A. Synthesis and biological activity of endomorphin-2 analogs incorporating Piperidine-2, 3- or 4-Carboxylic acids instead of proline in position 2. Chem. Biol. Drug. Des. 2008, 72, 91-94.

[63] Gao, Y.; Liu, X.; Liu, W.; Qi, Y.; Liu, X.; Zhou, Y.; Wang, R. Opioid receptor binding and antinociceptive activity of the analogues of endomorphin-2 and morphiceptin with phenylalanine mimics in the position 3 or 4. Bioorg. Med. Chem. Lett. 2006, 16, 3688-3692.

[64] Keresztes, A.; Borics, A.; Tóth, G. Recent advances in endomorphin engineering. ChemMedChem. 2010, 5, 1176-1196.

[65] Fichna, J.; do-Rego, J. C.; Kosson, P.; Costentin, J.; Janecka, A. Characterization of antinociceptive activity of novel endomorphin-2 and morphiceptin analogs modified in the third position. Biochem. Pharmacol. 2005, 69, 179-185.

[66] Tóth, G.; Kramer, T. H.; Knapp, R.; Lui, G.; Davis, P.; Burks, T. F.; Yamamura, H. I.; Hruby, V. J. [D-Pen ${ }^{2}$, D-Pen ${ }^{5}$ ]enkephalin analogues with increased affinity and selectivity for delta opioid receptors. J. Med. Chem. 1990, 33, 249-253.

[67] Tóth, G.; Keresztes, A.; Maslyanko, A.; Rónai, A. Endomorphin analogues with para-substituted Phenylalanine in position-4: Influence of physical-chemical properties on pharmacological profile. Joint Meeting on Medicinal chemistry, Budapest, Hungary. P-107, page-177, 2009.

[68] Tömböly, Cs.; Kövér K. E.; Péter, A.; Tourwé, D.; Biyashev, D.; Benyhe S.; Borsodi, A.; Al-Khrasani, M.; Rónai, A. Z.; Tóth, G. Structure-activity study on the Phe side chain arrangement of endomorphins using conformationally constrained analogues. J. Med. Chem. 2004, 47, 735-743.

[69] Wang, C. L.; Yao, J. L.; Yu, Y.; Shao, X.; Cui, Y.; Liu, H. M.; Lai, L. H.; Wang, R. Structure-activity study of endomorphin-2 analogs with C-terminal 
modifications by NMR spectroscopy and molecular modeling. Bioorg Med Chem. 2008, 16, 6415-6422.

[70] Mierke, D. F.; Nöbner, G.; Schiller, P. W.; Goodman, M. Morphiceptin analogs containing 2-aminocyclopentane carboxylic acids as a peptidomimetic for proline. Int. J. Peptide Protein Res. 1990, 35, 35-45.

[71] Janecka, A.; Staniszewska, R.; Gach, K.; Fichna, J. Enzymatic degradation of endomorphins. Peptides. 2008, 29, 2066-2073.

[72] Vanhoof, G.; Goossens, F.; De Meester, I.; Hendriks, D.; Scharpé, S. Proline motifs in peptides and their biological processing. FASEB J. 1995, 9, 736-744.

[73] Berne, P. F.; Schmitter, J. M.; Blanquet, S. Peptide and protein carboxyl-terminal labeling through carboxypeptidase Y-catalyzed transpeptidation. J. Biol. Chem. 1990, 265, 19551-19559.

[74] Rónai, A. Z.; Timár, J.; Makó, E.; Erdö, F.; Gyarmati, Z.; Tóth, G.; Orosz, G.; Fürst, S.; Székely, J. I. Diprotin A, an inhibitor of dipeptidyl aminopeptidase IV (EC 3.4.14.5) produces naloxone-reversible analgesia in rats. Life Sci. 1999, 64, $145-152$.

[75] Sakurada, C.; Sakurada, S.; Hayashi, T.; Katsuyama, S.; Tan-No, K.; Sakurada, T. Degradation of endomorphin-2 at the supraspinal level in mice is initiated by dipeptidyl peptidase IV: an in vitro and in vivo study. Biochem. Pharmacol. 2003, 66, 653-661.

[76] Péter, A.; Tóth, G.; Tömböly, C.; Laus, G.; Tourwé, D. Liquid chromatographic study of the enzymatic degradation of endomorphins, with identification by electrospray ionization mass spectrometry. J. Chromatogr. A. 1999, 846, 39-48.

[77] Szatmári, I.; Biyashev, D, Tömböly, C.; Tóth, G.; Mácsai, M.; Szabó, G.; Borsodi, A.; Lengyel, I. Influence of degradation on binding properties and biological activity of endomorphin 1. Biochem. Biophys. Res. Commun. 2001, 284, 771-776.

[78] Fülöp, F. The chemistry of 2-Aminocycloalkanecarboxylic Acids. Chem. Rev. 2001, 101, 2181-2204.

[79] Mallareddy, J. R.; Borics, A.; Keresztes, A.; Kövér, K. E.; Tourwé, D.; Tóth, G. Design, synthesis, pharmacological evaluation, and structure-activity 
study of novel endomorphin analogues with multiple structural modifications. J. Med. Chem. 2011, 54, 1462-1472.

[80] Paterlini, M. G.; Avitabile, F.; Ostrowski, B. G.; Ferguson, D. M.; Portoghese, P. S. Stereochemical requirements for receptor recognition of the $\mu$-opioid peptide endomorphin-1. Biophys. J. 2000, 78, 590-599.

[81] Leitgeb, B. Structural investigation of endomorphins by experimental and theoretical methods: hunting for the bioactive conformation. Chem. Biodivers. 2007, 4, 2703-2724.

[82] In, Y.; Minoura, K.; Ohishi, H.; Minakata, H.; Kamigauchi, M.; Sugiura, M.; Ishida, T.; Conformational comparison of mu-selective endomorphin-2 with its Cterminal free acid in DMSO solution by ${ }^{1} \mathrm{H}$ NMR spectroscopy and molecular modeling calculation. J. Pept. Res. 2001, 58, 399-412.

[83] Fiori, S.; Renner, C.; Cramer, J.; Pegoraro, S.; Moroder, L. Preferred conformation of endomorphin-1 in aqueous and membrane-mimetic environments. J. Mol. Biol. 1999, 291:163-175.

[84] Martinek, T. A.; Otvös, F.; Dervarics, M.; Tóth, G.; Fülöp, F. Ligand-based prediction of active conformation by 3D-QSAR flexibility descriptors and their application in 3+3D-QSAR models. J. Med. Chem. 2005, 48, 3239-3250.

[85] Borics, A, Tóth G. Structural comparison of $\mu$-opioid receptor selective peptides confirmed four parameters of bioactivity. J. Mol. Graph. Model. 2010, 28, 495505.

[86] Cahn, R. S.; Ingold, C. K.; Prelog, V. Specification of Molecular Chirality. Angew. Chem. Int. Ed. 1966,5, 385-415.

[87] Giordano, C.; Sansone, A.; Masi, A.; Lucente, G.; Punzi, P.; Mollica, A.; Pinnen, F.; Feliciani, F.; Cacciatore, I.; Davis, P.; Lai, J.; Ma, S. W.; Porreca, F.; Hruby. V. J. Synthesis and activity of endomorphin-2 and morphiceptin analogues with proline surrogates in position 2. Eur. J. Med. Chem. 2010, 45, 4594-4600.

[88] Gomes, I.; Gupta, A.; Filipovska, J.; Szeto, H. H.; Pintar, J. E.; Devi, L. A. A role for heterodimerization of $\mathrm{mu}$ and delta opiate receptors in enhancing morphine analgesia. Proc. Natl. Acad. Sci. U S A. 2004, 101, 5135-5139. 
[89] Spampinato, S.; Qasem, A. R.; Caliennim M.; Murari, G.; Gentilucci, L.; Tolomelli, A.; Cardillo, G. Antinociception by a peripherally administered novel endomorphin-1 analogue containing beta-proline. Eur. J. Pharmacol. 2003, 469, 89-95.

[90] Snook, L.A., Milligan, G., Kieffer, B.L., Massotte, D. Mu-delta opioid receptor functional interaction: Insight using receptor-G protein fusions. J. Pharmacol. Exp. Ther. 2006, 318:683-690.

[91] Alt, A.; Mansour, A.; Akil, H.; Medzihradsky, F.; Traynor, J. R.; Woods, J. H. Stimulation of guanosin-5'-O-(3-[ $\left.{ }^{35} \mathrm{~S}\right]$ thio)triphosphate binding by endogenous opioids acting at a cloned mu receptor. J. Pharmacol. Exp. Ther. 1998, 286, 282288.

[92] Mizoguchi, H.; Narita, M.; Wu, H. E.; Narita, M.; Suzuki, T.; Nagase, H.; Tseng, L. F. Differential involvement of $\mu_{1}$-opioid receptors in endomorphin and $\mu$ endorphin-induced G-protein activation in the mouse pons/medulla. Neuroscience. 2001, 100, 835-839.

[93] Spetea, M.; Monory, K.; Tömböly, Cs.; Tóth, G.; Tzavara, E.; Benyhe, S.; Hanoune, J.; Borsodi, A. In vitro binding and signaling profile of the novel $\mu$ opioid receptor agonist endomorphin 2 in rat brain membranes Biochem. Biophys. Res. Commun. 1998, 250, 720-725.

[93] Sim, L. J.; Liu, Q.; Childers, S. R.; Selley, D. E. Endomorphin-stimulated $\left[{ }^{35} \mathrm{~S}\right] \mathrm{GTP} \gamma \mathrm{S}$ binding in rat brain: evidence for partial agonist activity at $\mu$-opioid receptors. J. Neurochem. 1998, 70, 1567-1576.

[95] Harrison, C.; Smart, D.; Lambert, D.G. Stimulatory effects of opioids. Br. J. Anaesth. 1998, 81, 20-28.

[96] Rónai, A, Z.; Al-Khrasani, M.; Benyhe, S.; Lengyel, I.; Kocsis, L.; Orosz, G.; Tóth, G.; Kató, E.; Tóthfalusi, L. Partial and full agonism in endomorphin derivatives: comparison by null and operational model. Peptides. 2006, 27, 1507 1513.

[97] Kakizawa, K.; Shimohira, I.; Sakurada, S.; Fujimura, T.; Murayama, K.; Ueda, H. Parallel stimulations of in vitro and in situ $\left[{ }^{35} \mathrm{~S}\right] \mathrm{GTP} \gamma \mathrm{S}$ binding by endomorphin-1 and DAMGO in mouse brains. Peptides. 1998, 19, 755-758. 
[98] Narita, M. Effects of newly isolated opioid peptides on G-protein activation: usefulness of $\left[{ }^{35} \mathrm{~S}\right] \mathrm{GTP} \gamma \mathrm{S}$ binding study and its practical application. Jpn. J. Psychopharmacol. 1998, 18, 107-116.

[99] Narita, M.; Mizoguchi, H.; Oji, G. S.; Tseng, E. L., Suganuma, C., Nagase, H., Tseng, L. F. Characterization of endomorphin-1 and -2 on $\left[{ }^{35} \mathrm{~S}\right] \mathrm{GTP} \gamma \mathrm{S}$ binding in the mouse spinal cord. Eur. J. Pharmacol. 1998, 351, 383-387.

[100] Abbadie, C.; Rossi, G. C.; Orciuolo, A.; Zadina, J. E.; Pasternak, G. W. Anatomical and functional correlation of the endomorphins with mu opioid receptor splice variants. Eur. J. Neurosci. 2002, 16, 1075-1082.

[101] Mizoguchi, H.; Narita, M.; Oji, D. E.; Suganuma, C.; Nagase, H.; Sora, I.; Uhl, G. R..; Cheng, E. Y.; Tseng, L. F. The $\mu$-opioid receptor gene-dose dependent reductions in G-protein activation in the pons/medulla and antinociception induced by endomorphins in $\mu$-opioid receptor knockout mice. Neuroscience. 1999, 94, 203-207.

[102] Narita, M.; Mizoguchi, H.; Sora, I.; Uhl, G. R.; Tseng, L. F. Absence of G-protein activation by $\mu$-opioid receptor agonist in the spinal cord of $\mu$-opioid receptor knockout mice. Br. J. Pharmacol. 1999, 126, 451-456.

[103] Monory, K.; Bourin, M. C.; Spetea, M.; Tömböly, Cs.; Toth, G.; Matthes, H. W.; Kieffer, B. L.; Hanoune, J.; Borsodi, A. Specific activation of the $\mu$ opioid receptor (MOR) by endomorphin 1 and endomorphin 2. Eur. J. Neurosci. 2000, 12, 577-584.

[104] Choppin, G.; Liljenzin, J-O.; Rydberg, J. Radiochemistry and Nuclear Chemistry, Butterworth-Heinemann, Woburn, (Third Edition), (2002).

[105] Alvarez, L. W.; Cornog, R. Phys. Rev., 1939, 56, 613.

[106] Evans, E. A.; Warrell, D. C.; Elvidge, J. A.; Jones, J. R. Handbook of Tritium NMR Spectroscopy and Applications, John Wiley and Sons Inc, New York, (1985).

[107] Tóth, G.; Lovas, S.; Ötvös, F. Tritium labeling of neuropeptides. Methods Mol Biol. 1997, 73, 219-230.

[108] Wilzbach, K. E. J. Am. Chem. Soc. 1957, 79, 1013. 
[109] Oehlke, J.; Mittag, E.; Tóth, G.; Bienert, M.; Niedrich; H. J. Labelled Compd. Radiopharm.,1987, 24, 1483.

[110] Nägren, K.; Franzén, H. M.; Ragnarsson, U.; Längström, B. J. Labelled Compd. Radiopharm., 1988, 25, 141.

[111] Cooper, D.; Reich, E. Neurotoxin from venom of the cobra, Naja naja siamensis. Purification and radioactive labeling. J. Biol. Chem. 1972, 247, 3008-3013.

[112] Búzás, B.; Tóth, G.; Cavagnero, S.; Hruby, V. J.; Borsodi, A. Synthesis and binding characteristics of the highly delta-specific new tritiated opioid peptide, [3H]deltorphin II. Life Sci. 1992, 50, PL75-78.

[113] Shu, A. Y.L.; Heys, R.In Synth. and Appl. of Isotopically Labelled Compd., Elsevier, Amsterdam, 1991. pp 85.

[114] Hsi, R. S. P.; Stolle, W. T.; Bundy; G. L. J. Labelled Compd. Radiopharm., 1994, $24,1175$.

[115] Kozlowski, E. S.; Dischino, D. D.; Johnson, G. Synthesis of a tritium labeled rat enterostatin, Val-[3,4- $\left.{ }^{3} \mathrm{H}-\mathrm{Pro}\right]-\mathrm{Gly}-\left[3,4{ }^{3} \mathrm{H}-\mathrm{Pro}\right]-\mathrm{Arg}-\mathrm{Oh} . \quad J$ Label. Compds. Radiopharm. 1995, 36, 871-876.

[116] Felix, A. M.; Wang, C. T.; Liebman, A. A.; Delaney, C. M.; Mowles, T.; Burghardt, B. A.; Charnecki, A. M.; Meienhofer, J. Synthesis, biological activity, and tritiation of L-3, 4-dehydroproline-containing peptides. Int J Pept Protein Res. 1977, 10, 299-310.

[117] Labbé-Jullié, C.; Blanot, D.; Morgat, J. L.; Kitabgi, P.; Checler, F.; Vincent, J. P.; Granier, C.; Van Rietschoten, J. Radioactive analogs of neurotensin II. Preparation of tritiated neurotensin from a synthetic multi-unsaturated derivative. Biochimie. 1983, 65, 553-562.

[118] Keresztes, A.; Birkás, E.; Páhi, A.; Tóth, G.; Bakota, L.; Gulya, K.; Szücs, M. Pharmacology of a new tritiated endomorphin-2 analog containing the proline mimetic cis-2-aminocyclohexanecarboxylic acid. Peptides. 2011, 32, 722-728.

[119] Keresztes, A.; Tóth, G.; Fülöp, F.; Szücs, M. Synthesis, radiolabeling and receptor binding of $\left[{ }^{3} \mathrm{H}\right]\left[(1 S, 2 R) \mathrm{ACPC}^{2}\right]$ endomorphin-2. Peptides. 2006, 27, 3315-3321. 
[120] Eberle, A. N.; Siegrist, W.; Drozdz, R.; Verin, V. J.; Bagutti, C.; Solca, F.; Girard, J.; Zeller, A. proceeding in Synthesis and applications of isotopically labelled compounds 1991, E. Buncel and G. W. Kabalka, Eds., p. 110-115 (1992).

[121] Przewłocki, R.; Labuz, D.; Mika, J.; Przewłocka, B.; Tomboly, C.; Tóth, G. Pain inhibition by endomorphins. Ann. N. Y. Acad. Sci. 1999, 897, 154-164.

[122] Tömböly, Cs.; Dixit, R.; Lengyel, I.; Borsodi, A.; Tóth, G. Preparation of specifically tritiated endomorphins. J. Labelled Compds. Radiopharm. 2001, 44, $355-363$.

[123] Nevin, S. T.; Kabasakal, L.; Ötvös, F.; Tóth, G.; Borsodi, A. Binding characteristics of the novel highly selective delta agonist, $\left[{ }^{3} \mathrm{H}\right] \mathrm{II} \mathrm{e}^{5,6}$ deltorphin II. Neuropeptides. 1994, 26, 261-265.

[124] Kaiser, E.; Colescott, R.L.; Bossinger, C. D.; Cook, P. I. Color test for detection of free terminal amino groups in the solid-phase synthesis of peptides. Anal. Biochem. 1970, 34, 595-598.

[125] Péter, A.; Fülöp, F. High-performance liquid chromatographic methods for the separation of isomers of cis- and trans-2-aminocyclopentanecarboxylic acid. $J$. Chromatogr. A. 1995, 715, 219-226.

[126] Tóth, G.; Lebl, M.; Hruby, V. J. Chiral TLC separation of modified phenylalanine and tyrosine derivatives. J. Chromatogr. 1990, 504, 450-455.

[127] Tóth, G.; Lovas, S.; Ötvös F. In Molecular Biology, Neuropeptide Protocols, Irvine, G. B., Williams, C. H. (Eds.) Humana Press: Totowa, NJ. 1997, 73. 219.

[128] Bradford, M. M. A rapid and sensitive method for the quantitation of microgram quantities of protein utilizing the principle of protein-dye binding. Anal. Biochem. 1976, 72, 248-254.

[129] Biondi, B.; Giannini, E.; Negri, L.; Melchiorri, P.; Lattanzi, R.; Rosso, F.; Ciocca, L.; Rocchi. R. Opioid peptide synthesis and biological activity of new endomorphin analogues. Int. J. Pept. Res. Ther. 2006, 12, 145-151.

[130] Cardillo, G.; Gentilucci, L.; Qasem, A. R.; Sgarzi, F.; Spampinato, S. Endomorphin-1 analogues containing beta-proline are $\mu$-opioid receptor agonists and display enhanced enzymatic hydrolysis resistance. J. Med. Chem. 2002, 45, 2571-2578. 
[131] Rónai, A. Z.; Al-Khrasani, M.; Benyhe, S.; Lengyel, L.; Kocsis, L.; Orosz, G.; Tóth, G.; Kató, E.; Tóthfalusi, L. Partial and full agonism in endomorphin derivatives: comparison by null and operational model. Peptides. 2006, 27, 15071513.

[132] Sim, L. J.; Liu, Q.; Childers, S. R.; Selley, D. E. Endomorphin-stimulated $\left[{ }^{35} \mathrm{~S}\right] \mathrm{GTP} \gamma \mathrm{S}$ binding in rat brain: evidence for partial agonist activity at $\mu$-opioid receptors. J. Neurochem.1998, 70, 1567-1576.

[133] Mallareddy，J. R.; Tóth，G.; Fazakas，C.; Molnár， J.; Nagyőszi， P.; Lipkowski' A. W.; Krizbai, I.A.; Wilhelm, I. Transport characteristics of endomorphin-2 analogues in brain capillary endothelial cells. Chem. Biol. Drug. Des. 2012, 79, 507-513.

[134] Kovacs, G.; Petrovszki, Z.; Mallareddy, J. R.; Tóth, G.; Benedek, G.; Horvath, G. Characterization of Antinociceptive Potency of Endomorphin-2 Derivatives with Unnatural Amino Acids. Acta Physiol Hung. (in print)

[135] Husten, E. J.; Eipper, B. A. The membrane-bound bifunctional peptidyglycine aamidating monooxygenase protein. J. Bio. Chem. 1991, 266, 17004-17010.

[136] Bradbury, A. F.; Smyth, D. G. Peptide amidation. Trends Biochem. Sci. 1991, 16, 112-115.

[137] Tóth, G.; Mallareddy, J. R.; Tóth, F.; Lipkowski, A. W.; Tourwé, D. Radiotracers, tritium labelling of neuropeptides. Arkivoc. 2012 (v) 163-174.

[138] Balboni, G.; Salvadori, S.; Guerrini, R.; Negri, L.; Giannini, E.; Jinsmaa, Y.; Bryant, S. D.; Lazarus, L. H. Potent delta-opioid receptor agonists containing the Dmt-Tic pharmacophore. J. Med. Chem. 2002, 45, 5556-5563.

[139] Okada, Y.; Tsuda, Y.; Fujita, Y.; Yokoi, T.; Sasaki, Y.; Ambo, A.; Konishi, R.; Nagata, M.; Salvadori, S.; Jinsmaa, Y.; Bryant, S. D.; Lazarus, L. H. Unique highaffinity synthetic mu-opioid receptor agonists with central- and systemicmediated analgesia. J. Med. Chem. 2003, 46, 3201-3219. 
[140] Torino, D.; Mollica, A.; Pinnen, F.; Feliciani, F.; Lucente, G.; Fabrizi, G.; Portalone, G.; Davis, P.; Lai, J.; Ma, S. W.; Porreca, F.; Hruby, V. J.Synthesis and evaluation of new endomorphin-2 analogues containing (Z)-alpha,betadidehydrophenylalanine (Delta(Z)Phe) residues. J. Med. Chem. 2010, 53, 45504554.

[141] Torino, D.; Mollica, A.; Pinnen, F.; Feliciani, F.; Lucente, G.; Fabrizi, G.; Portalone, G.; Davis, P.; Lai, J.; Ma, S. W.; Porreca, F.; Hruby, V. J. Synthesis and evaluation of new endomorphin-2 analogues containing (Z)- $\alpha, \beta$ didehydrophenylalanine ( $\Delta^{\mathrm{Z}} \mathrm{Phe}$ ) residues. J. Med. Chem. 2010, 53, 4550-4554.

[142] Fichna, J.; do-Rego, J. C.; Janecki, T.; Staniszewska, R.; Poels, J.; Broeck, J. V.; Costentin, J.; Schiller, P. W.; Janecka, A. Novel highly potent mu-opioid receptor antagonist based on endomorphin-2 structure. Bioorg Med Chem Lett. 2008, 18, 1350-1353.

[143] Harrison, C.; Traynor, J. R. The $\left[{ }^{35} \mathrm{~S}\right] \mathrm{GTP} \gamma \mathrm{S}$ binding assay: approaches and applications in pharmacology. Life Sci. 2003, 74, 489-508.

[144] Bidlack, J. M.; Parkhill, A. L. Assay of G protein-coupled receptor activation of $\mathrm{G}$ proteins in native cell membranes using $\left[{ }^{35} \mathrm{~S}\right] \mathrm{GTP} \gamma \mathrm{S}$ binding. Methods Mol. Biol. 2004, 237, 135-143.

[145] Yao, J.; Feher, V. A.; Espejo, B. F.; Reymond, M. T.; Wright, P. E.; and Dyson, H. J. Stabilization of a type VI turn in a family of linear peptides in water solution. J. Mol. Biol. 1994, 243, 736-753.

[146] George, S. R.; Fan, T.; Xie, Z.; Tse, R.; Tam, V.; Varghese, G.; O'Dowd, B. F. Oligomerization of $\mu$ - and $\delta$-opioid receptors. Generation of novel functional properties. J. Biol. Chem. 2000, 275, 26128-26135.

[147] Pasternak, G. W. Multiple mu opiate receptors: biochemical and pharmacological evidence for multiplicity. Biochem Pharmacol. 1986, 35, 361-364.

[148] Perlikowska, R.; Fichna, J.; Wyrebska, A.; Poels, J.; Vanden Broeck, J.; Toth, G.; Storr, M.; do Rego, J. C.; Janecka, A. Design, synthesis and pharmacological characterization of endomorphin analogues with non-cyclic amino acid residues in position 2. Basic Clin Pharmacol Toxicol. 2010, 106, 106-103. 
[149] Shi, Z-H.; Wei, Y-Y.; Wang, C-J.; Yu, L. Synthesis and analgesic activities of endomorphin-2 and its analogues. Chem.Biodivers. 2007, 4, 458-467.

[150] Perlikowska, R.; Gach, K.; Fichna, J.; Tóth, G.; Walkowiak, B.; do-Rego, J. C.; do-Rego, J. C.; Janecka, A. Biological activity of endomorphin and [Dmt1] endomorphin analogs with six-membered proline surrogates in position 2. Bio. Org. Med. Chem. 2009, 17, 3789-3794.

[151] Labuz, D.; Chocyk, A.; Wedzony, K.; Toth, G.; Przewlocka, B. Endomorphin-2, deltorphin II and their analogs suppress formalin-induced nociception and c-Fos expression in the rat spinal cord. Life Sci. 2003, 73, 403-412. 


\section{9. Összefoglaló}

Az opioidok kutatásának fő célja hatékony fájdalomcsillapítók kifejlesztése, amelyek az opiátok káros mellékhatásait (fizikai függőség, tolerancia és légzés depresszió) kiküszöbölhetik és hatékonyan helyettesíthetik a morfint. Marha agyból majd később humán agyból izolált két endogén peptid, endomorfin-1 és -2 (EM-1, H-Tyr-ProTrp-Phe- $\mathrm{NH}_{2} ;$ EM-2, H-Tyr-Pro-Phe-Phe- $\mathrm{NH}_{2}$ ) nagy affinitással és szelektivitással kötődik a $\mu$-opioid receptorokhoz. Mivel az endomorfinok nagy affinitással kötődnek a $\mu$ opioid receptorokhoz, és ezen receptorok felelősek a fájdalomérzékeléséért és modulációjáért, ezen tetrapeptidek fontos modellek lettek a fájdalomcsillapítók kifejlesztésének kutatásában. Az endomorfinok használatát számos tényező befolyásolja, pl. rövid hatástartam, hatástalan ok per os adagolás esetén, a kotlátozoth vér-agy gáton való átjutások és a proteolitikus enzimekkel szemben metabolikus stabilitásuk gyenge. A korlátozó tényzők leküzdése érdekébeni több nem természetes aminosavval (Dmt ${ }^{1}$, cisz-

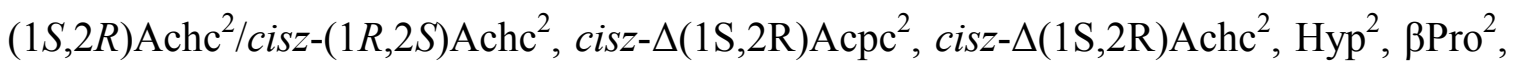
$\left.(2 R, 3 R) \beta \mathrm{MePhe}^{4} /(2 S, 3 S) \beta \mathrm{MePhe}^{4}\right)$ szubsztituált endomorfin analógot szintetizáltunk. Az így szubsztituált endomorfin analógok a proteolitikus stabilitás növekedéséhez vezettek, miközben megtartották vagy növelték azok biológiai aktivítását.

A peptid szintézist Boc védőcsoporttal ellátott aminosavakkal 4-Metilbenzhidrilamin gyantán, szilárd fázisú peptidszintézis módszerével valósítottuk meg. Az új endomorfin analógok hatékonyságának és szelektivitásának elemzése patkány agyi membránpreparátumon radioligand-kötési teszttel történt. A $\mu$-receptor affinitás méréshez $\left[{ }^{3} \mathrm{H}\right] \mathrm{DAMGO}-\mathrm{t}$, míg a $\delta$-receptor affinitás méréshez $\left[{ }^{3} \mathrm{H}\right] \mathrm{Ille}{ }^{5,6}$-deltorphin II-t használtunk. Az új vegyületek koncentráció függő módon versengtek a radiojelzett $\mu$ - és $\delta$-receptor ligandumokkal a receptor kötési helyekért. [ $\left.{ }^{35} \mathrm{~S}\right] \mathrm{GTP} \gamma \mathrm{S}$ mérésekkel határoztuk meg a ligandumok funkcionális tulajdonságait.

A receptor kötési vizsgálatok analízise kimutatta hogy mindkét endomorfin esetében a $(1 S, 2 R) \mathrm{Achc}^{2}$ és a $(2 S, 3 S) \beta \mathrm{MePhe}^{4}$ együttes használata az eredeti peptidekhez képest hasonlóan potens analógokhoz vezetett. A kapott eredmények alátámasztották, 
hogy a Dmt ${ }^{1}$ szubsztitució fokozza a $\mu$-opioid receptor affinitást, miközben csökkenti a ligandumok szelektivitását. A $(2 R, 3 R) \beta \mathrm{MePhe}{ }^{4}$-al szubsztituált analóg kisebb affinitást mutatott, mint a másik izomer a $(2 S, 3 S) \beta \mathrm{MePhe}{ }^{4}$ tartalmú peptid. Az $\mathrm{Achc}^{2}$ és a pFPhe együttes szubsztituciója olyan analógokat eredményezett, melyek bioaktivitása az aliciklikus $\beta$-aminosavak kiralitásától függött. Az összes analóg közül a $\mathrm{Dmt}^{1}$, $(1 S, 2 R) \mathrm{Achc}^{2}$, pFPhe ${ }^{4}$-endomorfin-2 rendelkezett a legnagyobb $\mu$-opioid receptor affinitással $\left(K_{\mathrm{i}}=0.13 \mathrm{nM}\right)$.

Hyp $^{2}$ szubsztitució csökkentette $\mu$-opioid receptor affinitást $\left(K_{\mathrm{i}}=44 \mathrm{nM}\right)$, A $\beta$ Pro $^{2}$ tartalmú analóg alacsonyabb affinitáshoz vezetett $\left(K_{\mathrm{i}}=27 \mathrm{nM}\right)$ az eredeti endomorfin-2 höz képest $\left(K_{\mathrm{i}}=1.35 \mathrm{nM}\right)$. A peptidgerinc $\mathrm{CH}_{2}$-csoporttal való meghosszabítása ( $\beta$ Pro), a Pro tercier amid molekularész megörzése mellett, nem elönyös az endomorfin-2 $\mu$ receptor aktivitására. A $\beta \mathrm{Pro}^{2}$ szubsztitució esetében észlelt hatás nem biztos hogy általánosan alkalmazható minden $\mu$-receptor ligandumra, mivel egy korábbi vizsgálat során a $\beta$ Pro-endomorfin-1 a DAMGO-hoz és az endomorfin-1-hez hasonló $\mu$-receptor affinitást, "efficacy" profilt és agonista karaktert mutatott. A - $\mathrm{CH}_{2}$-csoport beillesztése a pirrolidin gyürü és a kaboxil csoport közé ( $\beta$ Pro) az endomorfinban, másképpen befolyásolja a receptor-ligandum kölcsönhatást, ha a következö aminosav Trp vagy Phe. A cisz-(1S,2R) $\Delta \mathrm{Acpc}^{2} / c i s z-(1 S, 2 R) \Delta \mathrm{Achc}^{2}$ tartalmú analógok az eredeti endomorfin-2höz hasonló affinitást mutattak. A telítetlen aliciklikus $\beta$-aminosav tartalmú endomorfin analógok kötési affinitása összehasonlítható a telített $\beta$-aminosav tartalmú endomorfin analógokéval. A cisz-( $1 S, 2 R) \Delta \mathrm{Acpc}^{2}$-endomorfin-2 azonos affinitást $\left(K_{\mathrm{i}}=1.3 \mathrm{nM}\right)$ és nagyobb $\mu$-opioid receptor szelektivítást mutatott a eredeti peptidhez képest.

A heterológ leszorítási kisérletek eredményei alapján választottuk ki a legpotensebb analógokat a $\left[{ }^{35} \mathrm{~S}\right] \mathrm{GTP} \gamma \mathrm{S}$ mérésekhez. A potencia $\left(\mathrm{EC}_{50}\right)$ és a hatásfok (efficacy, $E_{\max }$ ) értékekeket a tiszta agonista DAMGO értékeihez hasonlítottuk. A vegyületek dózis függő módon stimulálták a funkcionális [ $\left.{ }^{35} \mathrm{~S}\right] \mathrm{GTP} \gamma \mathrm{S}$ kötést. Az endomorfin-1 és az endomorfin-2 a DAMGO-hoz hasonló $\mathrm{EC}_{50}$ értéket, de alacsonyabb hatásfokot mutat, mely alátámasztja hogy az endomorfinok parciális agonisták. A cisz$(1 S, 2 R) \Delta \mathrm{Acpc}^{2}, \quad$ cisz-( $(1 S, 2 R) \Delta \mathrm{Achc}^{2}, \quad(1 S, 2 R) \mathrm{Achc}^{2}$, és $\quad(2 S, 3 S) \beta \mathrm{MePhe}^{4}$ tartalmú 
analógok nagyobb hatásfokot mutattak, tiszta agonistaként viselkednek. Нyp ${ }^{2}$ szubsztitució az endomorfin-2-ben alacsonyabb hatásfokot eredményezett, mely mérsékelt agonista hatást sugall. A $\beta$ Pro $^{2}$ tartalmú analóg szolgáltatta a legalacsonyabb hatásfokot, gyenge agonistaként viselkedik. A naloxon jelenlétében elvégzett [ $\left.{ }^{35} \mathrm{~S}\right] \mathrm{GTP} \gamma \mathrm{S}$ mérések eredménye kimutatta hogy a ligandumok opioid receptorokon keresztül aktiválják a G-proteineket.

A biológiai aktivitási eredmények alapján a hatékony analógokon stabilitási vizsgálatokat végeztünk patkányagyi membrán preparatumon. Az $(1 S, 2 R) \mathrm{Achc}^{2}$ tartalmú analógok felezési ideje (>20 óra) jelentősen emelkedett az eredeti endomorfinok felezési idejéhez $\left(\mathrm{t}_{1 / 2}=5-7\right.$ perc $)$ képest, mely az új analógok enzim rezisztenciáját bizonyítja. Az endomorfin-2 esetében a $\mathrm{Hyp}^{2}$ szubsztitúció $3 \mathrm{x}-\mathrm{os}$, a $\beta$ Pro $^{2}$ beépítése $6 \mathrm{x}$-os növekedést eredményezett a proteolitikus stabilitásban az eredeti vegyülethez képest. Ezen eredmények alátámasztják, hogy az aliciklikus $\beta$-aminosavak beépítése proteolitikusan stabil analógokhoz vezet.

Laboratóriumunkban számos tríciált endomorfin-, és neuropeptid analógot állítottunk elő, különböző biokémiai vizsgálatokhoz. A tríciummal jelzett radioaktív peptidek előnye, hogy a radioaktív anyag szerkezete megegyezik az eredeti peptidével, így a biológiai aktívitásuk is hasonló. A tríciált ligandumokat felhasználtuk prekurzor proteinek bioszintetikus útvonalának keresésére és homológ vagy heterológ leszorítási kísérletekben az új analógok biológiai jellemzésére.

A leghatékonyabb endomorfin-2 analógokat in vivo krónikus izületi fájdalom modelben spinális szinten vizsgáltuk az anti-allodinikus hatások felderítésére. Az allodynia egy olyan állapot, amelyben egy rendesen nem fájdalmas inger, fájdalmat vált ki. Morfint használtunk kontrollnak. Az összes analóg koncentráció függő módon váltott ki antinociceptív hatást. Ezen eredmények azt sugallják, hogy a Dmt, az aliciklikus $\beta$ aminosavak, a $\beta$ MePhe, és a pFPhe aminosavak beépítése az endomorfin-2-ben egy ígéretes stratégia lehet a peptidek biohasznosíthatóságának növelésére, és szerepet játszhat új endomorfin analógok kifejlesztésében, melyek fokozott terápiás lehetőséggel 
bírnak. Mindamellett további vizsgálatok szükségesek ezen ligandumok lehetséges mellékhatásainak felderítésére.

Korábbi eredmények alapján ismert hogy az endomorfinok hatékony, nagy szelektívivású $\mu$-opioid receptor agonisták. A gyenge metabolikus stabilitás és a korlátozott vér-agy gáton való átjutás, mind eimitálja a fájdalom klinikai kezelését endomorfinok szisztémás adásával. Az endomorfin-1-ben és endomorfin-2-ben végrehajtott számos ígéretes szerkezeti módosítás megnövekedett antinocicepcióhoz vezetett, melyet a peptid perifériás beadása után észleltek, ez a hatás a jobb vér-agy gát permeablitásnak vagy a megnövekedett degradáció elleni rezisztenciának vagy mindkettőnek tulajdonítható. A vizsgált endomorfin-2 analógok [Dmt-Pro-Phe-Phe- $\mathrm{NH}_{2}$, Tyr-( $1 S, 2 R)$ Acpc-Phe-Phe-NH $\mathrm{N}_{2}$, Tyr-( $\left.1 S, 2 R\right)$ Achc-Phe-Phe- $\left.\mathrm{NH}_{2}\right]$ viszonylag alacsony, de jobb vér-agy-gát permeabilitást mutattak az eredeti peptidhez képest. Az agyi endotél sejtek életképességére egyik vizsgált peptid sem hatott citotoxikusan. A jobb vér-agy gát permeablitás, az antinociceptiv hatás és a megnövekedett enzimatikus rezisztencia mind azt bizonyítja hogy ezen peptidek prekurzorként szolgálhatnak opioid gyógyszerek fejlesztésében. 


\section{Summary}

A major goal in opioid research is the development of novel analgesics having fewer side effects (physical dependence, tolerance and respiratory depression), that can substitute morphine. Two endogenous (Endomorphins: EM-1, H-Tyr-Pro-Trp-Phe- $\mathrm{NH}_{2}$; EM-2, H-Tyr-Pro-Phe-Phe- $\mathrm{NH}_{2}$ ) peptides were isolated from bovine brain and subsequently from the human central nervous system with a high affinity and selectivity for $\mu$-opioid receptors. Since endomorphins have high affinity for $\mu$-opioid receptors and these receptors mediate many of biological functions that include pain perception and modulation, these tetrapeptides became important model peptides in the research towards analgesics. Exogenous application of endomorphins suffers from serious limitations, including short duration of action, lack of activity after oral administration, relative inability to cross the blood-brain barrier into the central nervous system and poor metabolic stability. In order to overcome the afore mentioned objectives, we synthesized a pool of endomorphin analogues by incorporating unnatural amino acids, such as $\mathrm{Dmt}^{1}$, cis-(1S,2R)Achc ${ }^{2} / c i s-(1 R, 2 S) \mathrm{Achc}^{2}, c i s-\Delta(1 \mathrm{~S}, 2 \mathrm{R}) \mathrm{Acpc}^{2}, c i s-\Delta(1 \mathrm{~S}, 2 \mathrm{R}) \mathrm{Achc}^{2}, \mathrm{Hyp}^{2}, \beta \mathrm{Pro}^{2}$, $(2 R, 3 R) \beta \mathrm{MePhe}^{4} /(2 S, 3 S) \beta \mathrm{MePhe}^{4}, \mathrm{pFPhe}^{4}$. Such modifications yielded analogues with an increased proteolytic stability while retaining or enhancing the biological activity.

Peptide synthesis was carried out by manual solid phase peptide synthesis method on 4-methylbenzhydrylamine resin using Boc-protected amino acids. The potency and selectivity of the newly synthesized endomorphin analogues were evaluated by means of radioligand binding assays in rat brain membrane homogenate. $\left[{ }^{3} \mathrm{H}\right]$ DAMGO was used to measure the $\mu$-receptor affinity, $\left[{ }^{3} \mathrm{H}\right] I \mathrm{Ie}^{5,6}$-deltorphin- 2 was applied to evaluate the $\delta$ receptor affinity. All the new compounds competed with the radiolabeled $\mu$ - and $\delta$ receptor ligands in a concentration dependent manner for the receptor binding sites. The functional properties were evaluated using $\left[{ }^{35} \mathrm{~S}\right] \mathrm{GTP} \gamma \mathrm{S}$ binding assays.

Analysis of the receptor binding data revealed that co-application of $(1 S, 2 R) \mathrm{Achc}^{2}$ and $(2 S, 3 S) \beta \mathrm{MePhe}^{4}$ in both endomorphins resulted in comparably potent analogues relative to the native peptides. The obtained results confirmed that the use of $\mathrm{Dmt}^{1}$ 
augments the affinity for $\mu$-opioid receptors but, at the same time, decreases selectivity of the ligands. Analogues containing corresponding $(2 R, 3 R) \beta \mathrm{MePhe}^{4}$ residue exhibited lower affinities than those with the other isomer $(2 S, 3 S) \beta \mathrm{MePhe}{ }^{4}$. Co-substitution of Achc $^{2}$ with $\mathrm{pFPhe}^{4}$ yielded analogues with diverse bioactivities depending on the chirality of the alicyclic $\beta$-amino acids. Among all, the analogue containing $\mathrm{Dmt}^{1}$, $(1 S, 2 R) \mathrm{Achc}^{2}$ and $\mathrm{pFPhe}{ }^{4}$ displayed the highest $\mu$-opioid receptor affinity $\left(K_{\mathrm{i}}=0.13 \mathrm{nM}\right)$ with high selectivity. Incorporation of $\mathrm{Hyp}^{2}$ resulted in a decreased affinity to $\mu$-opioid receptors $\left(K_{\mathrm{i}}=44 \mathrm{nM}\right)$, in contrast to affinity values measured with the radiolabeled opioid antagonist naloxone in crude rat brain membrane. Insertion of $\beta \mathrm{Pro}^{2}$ resulted in lower affinity $\left(K_{\mathrm{i}}=27 \mathrm{nM}\right)$ compared to that of parent EM-2 $\left(K_{\mathrm{i}}=1.35 \mathrm{nM}\right)$. Insertion of a polar -OH group on the $\mathrm{Pro}^{2}$ side chain and the extension of the backbone by a $-\mathrm{CH}_{2}$ group, while preserving the tertiary amide moiety of Pro has disadvantageous effects on $\mu$-receptor activity of EM-2. However, the observed effect of $\beta \mathrm{Pro}^{2}$ substitution may not be applicable generally for all $\mu$-receptor ligands, since in a previous study $\beta$ Pro-EM- 1 exhibited $\mu$-receptor affinity, efficacy and agonist behavior similar to those of DAMGO and EM-1. This indicates that the incorporation of a $-\mathrm{CH}_{2}$ - group between the pyrrolidine ring and the carboxyl group of the second residue of the endomorphin sequence may affect receptor-ligand interactions differently when the following amino acid residue is Trp or Phe. Furthermore, diastereomeric $\beta \mathrm{Pro}^{2}$ substitution in morphiceptin yielded analogues with different biological activity profile, $(R) \beta \operatorname{Pro}^{2}$-morphiceptin had higher $\mu$ receptor affinity than $(S) \beta \mathrm{Pro}^{2}$-morphiceptin. Analogues bearing $c i s-(1 S, 2 R) \Delta \mathrm{Acpc}^{2} /$ cis- $^{-}$ $(1 S, 2 R) \Delta \mathrm{Achc}^{2}$ displayed comparable affinities relative to the parent EM-2. The observed propensity of binding affinities for unsaturated alicyclic $\beta$-amino acid containing analogues is comparable with those of saturated alicyclic $\beta$-amino acid containing endomorphin analogues. Ligand with $c i s-(1 S, 2 R) \Delta \mathrm{Acpc}^{2}$ exhibited equal affinity $\left(K_{\mathrm{i}}=\right.$ $1.3 \mathrm{nM})$ and higher selectivity for $\mu$-opioid receptor relative to parent EM-2.

On the basis of the heterologous displacement binding results, the most potent analogues were selected for $\left[{ }^{35} \mathrm{~S}\right] \mathrm{GTP} \gamma \mathrm{S}$ binding assays. Potency $\left(\mathrm{EC}_{50}\right)$ and efficacy $\left(E_{\max }\right)$ values were compared with those of the $\mu$-receptor full agonist DAMGO. Dosedependent increases were observed for selected compounds in $\left[{ }^{35} \mathrm{~S}\right] \mathrm{GTP} \gamma \mathrm{S}$ binding. Both 
parent ligands exhibited comparable potencies, but lower efficacies were observed as compared to DAMGO, confirming that endomorphins are partial agonists. Analogues containing cis- $(1 S, 2 R) \Delta \mathrm{Acpc}^{2}$, cis- $(1 S, 2 R) \Delta \mathrm{Achc}^{2},(1 S, 2 R) \mathrm{Achc}^{2}$, and $(2 S, 3 S) \beta \mathrm{MePhe}^{4}$ displayed higher efficacies, acting as full agonists. Substitution of Hyp ${ }^{2}$ in EM-2 resulted in lower efficacy, suggesting it as a moderate agonist. Incorporation of $\beta \mathrm{Pro}^{2}$ yielded the analogue with lowest efficacy, behaving as a weak agonist. The analysis of $\left[{ }^{35} \mathrm{~S}\right] \mathrm{GTP} \gamma \mathrm{S}$ binding assay results, performed in the presence of naloxone, revealed that the ligands predominantly activate G-proteins through opioid receptors.

Based on biological data, highly potent analogues were selected and their resistance against proteolytic enzymatic degradation was evaluated. The analogues containing $(1 S, 2 R) \mathrm{Achc}^{2}$ were shown to have prolonged half-lives $(>20 \mathrm{~h})$ in contrast with the parent endomorphins $\left(t_{1 / 2}=5-7 \mathrm{~min}\right)$, pointing to the enzyme resistance of the new analogues. Incorporation of $\mathrm{Hyp}^{2}$ and $\beta \mathrm{Pro}^{2}$ increased the proteolytic stability 3 - and 6 fold higher, respectively, compared to the parent compound EM-2. These results confirmed that insertion of alicyclic $\beta$-amino acids results in proteolytically stable analogues.

Several endomorphin and neuropeptide analogues were tritiated in our laboratory to use as a tool in different biochemical assays such as in vitro radioligand receptor binding assays, radioimmunoassays. The advantage of tritium labeled radioactive peptides is that the structure of the radioactive material is the same as the parent peptide, so the biological activity is identical. Tritiated ligands are used in finding biosynthetic pathways of precursor proteins; in homologue or heterologue displacement studies to characterize the new derivatives.

Highly potent EM-2 analogues were selected to investigate anti-allodynic effects at spinal level in in vivo chronic joint pain model. Allodynia is a pain due to a stimulus which does not normally provoke pain. Morphine was used as a positive control. All of the analogues elicited an antinociceptive effect in a concentration dependent manner. These results suggest that insertion of Dmt, alicyclic $\beta$-amino acids, $\beta \mathrm{MePhe}$, and $\mathrm{pFPhe}$ 
into different positions in the EM-2 might be a promising strategy to enhance bioavailability of peptides and may serve a role in the development of novel endomorphin analogues with increased therapeutic potential. However, further studies are required to reveal the possible side-effects of these ligands.

As previously described endomorphins are potent and highly selective $\mu$-opioid receptor agonists. The clinical treatment of pain with systemic administration of endomorphins is impeded by their poor metabolic stability and limited ability to cross the BBB. Several promising structural modifications of both endomoprhin-1 and -2 resulted in improved antinociception that was observed following peripheral administration of the peptide, which may be attributed to improved brain delivery, increased resistance against degradation or both. Here, the evaluated EM-2 analogues [Dmt-Pro-Phe-Phe- $\mathrm{NH}_{2}$, Tyr$(1 S, 2 R)$ Acpc-Phe-Phe- $\mathrm{NH}_{2}, \quad$ Tyr-(1S,2R)Achc-Phe-Phe- $\left.\mathrm{NH}_{2}\right]$ were found to have relatively low, but improved blood-brain-barrier permeability properties compared to the native endmorphin-2. None of the peptides had shown cytotoxic effects on the viability of the brain endothelial cells. The combined results of blood-brain barrier permeabilities, antinociceptive effect and their enhanced enzymatic resistance demonstrate that these peptides can serve as precursors for the development of successful opioid drugs. 


\section{List of publications}

\subsection{List of thesis related publications}

2011:

Mallareddy, J. R.; Borics, A.; Keresztes, A.; Kövér, K. E.; Tourwé, D.; Tóth.G. Design, Synthesis, Pharmacological Evaluation, and Structure-Activity Study of Novel Endomorphin Analogues with Multiple Structural Modifications.

Journal of Medicinal Chemistry, 54: 1462-1472.

Impact Factor: $\mathbf{5 . 2 0 7}$

2012:

Mallareddy, J. R.; Tóth, G.; Fazakas, C.; Molnár, J.; Nagyőszi, P.; Lipkowski’ A. W.; Krizbai, I.A.; Wilhelm, I. Transport Characteristics of Endomorphin-2 Analogues in Brain Capillary Endothelial Cells.

Chemical Biology \& Drug Design, 79: 507-513.

Impact Factor: $\mathbf{2 . 5 2 7}$

Tóth, G.; Mallareddy, J. R.; Tóth, F.; Lipkowski, A. W.; Tourwé, D. Radiotracers, Tritium Labelling of Neuropeptides.

Arkivoc, (v): 163-174.

Impact Factor: 1.096

Sum of impact factor: $\mathbf{8 . 8 3}$ 


\subsection{List of not related to the thesis publications}

2012:

Németh, K.; Mallareddy, J. R.; Domonkos, C.; Visy, J.; Géza, T.; Péter, A. Stereoselective Analysis of Tetrapeptide Diastereomers: Resolution of Biologically Active Endomorphin Analogues by Capillary Electrophoresis using Cyclodextrins.

Journal of Pharmaceutical and Biomedical Analysis (under review)

Kovács, G.; Petrovszki, Z.; Mallareddy, J. R.; Tóth, G.; Benedek, G.; Horváth, G. Characterization of Antinociceptive Potency of Endomorphin-2 Derivatives with Unnatural Amino Acids.

Acta Physiologica Hungarica (in print)

Impact Factor: 1.226

2011:

Vandormael, B.; Wachter, R. D.; Martins, J. C.; Hendrickx, P. M. S.; Keresztes, A.; Ballet, S.; Mallareddy, J. R.; Tóth, F.; Tóth, G.; Tourwé, D. Asymmetric Synthesis and Conformational Analysis by NMR and MD of Aba- and $\alpha$-MeAba-Containing Dermorphin Analogs.

ChemMedChem, 6: 2035-2047.

Impact Factor: 3.306

Sum of impact factor: $\mathbf{4 . 5 3 2}$ 


\subsection{Manuscripts under preparation}

Borics, A.; Mallareddy, J. R.; Tímári, I.; Kövér, K. E.; Keresztes, A.; Tóth, G. The Effect of Pro $^{2}$ Modifications on the Structural and Pharmacological Properties of Endomorohin-2.

Tóth, F.; Kleczkowska, P.; Lipkowski, A. W.; Mallareddy, J. R.; Tourwé, D.; Tóth, G.; Bojnik, E.; Benyhe, S. Synthesis and Binding Characteristics of a Neurotensin-like Peptide: $\left[{ }^{3}\right.$ H]Neuromedin-N.

\subsection{Oral presentations}

2009:

Mallareddy, J. R.; Keresztes, A.; Tóth, G "Investigations of Endomorphin-2 Biosynthesis" in Annual Meeting of the Peptide Committee of the Hungarian Academy of Sciences, Balatonszemes, Hungary.

2010:

Mallareddy, J. R. "Design, Synthesis and Biological Evaluation of Chemically Multiple Modified Endomorphins" in Young Organic Chemist symposium organized by Department of Chemistry, University of Szeged, Szeged, Hungary.

\section{1:}

Mallareddy, J. R.; Borics, A.; Keresztes, A.; Tóth, G. "Design and Synthesis of Pharmacologically Active Endomorphins" in Annual Meeting of the Peptide Committee of the Hungarian Academy of Sciences, Balatonszemes, Hungary.

Mallareddy, J. R. "Effects of Unnatural Amino Acids on Bioactivity of Endomorphins" in Young Organic Chemist symposium organized by Department of Chemistry, University of Szeged, Szeged, Hungary. 


\subsection{Posters}

2009:

Mallareddy, J. R.; Csibrany, B.; Keresztes, A.; Tóth, G. From Precursor to Peptide: Evidence for endomorphin-2 Biosyntheis?. $12^{\text {th }}$ Meeting of the Hungarian Neuroscience Society, Budapest, Hungary. (2009)

2010:

Mallareddy, J. R.; Borics, A.; Keresztes, A.; Tóth, G. Design, Synthesis and Pharmacological Evaluation of Novel Endomorphin analogues with Multiple Structural Modifications. $8^{\text {th }}$ European Opioid Conference, Krakow, Poland. PS I - 7

Tóth, G.; Mallareddy, J. R.; Borics, A.; Kövér, K. E.; Keresztes, A. Design, Synthesis and Biological Evaluation of Novel Endomorphins with Multiple Structural Modifications. Proceedings of $31^{\text {st }}$ European Peptide Symposium, European Peptide Society, Copenhagen, Denmark. Page 454-455.

Tomczyszyn, A.; Lipkowski, A. W.; Toth, G.; Keresztes, A.; Mallareddy, J. R.; Misicka, A. Synthesis of Tritiated Ligand for Binding Assays to Tachykinin Receptors. $20^{\text {th }}$ Polish Peptide Symposium, Wladyslawowo, Poland.

\section{1:}

Mallareddy, J. R.; Borics, A.; Keresztes, A.; Tóth, G. Influence of Proline Mimetics on Bioactivity of Endomorphin-2. $4^{\text {th }}$ European Conference on Chemistry for Life Sciences, Budapest, Hungary. P170

Tóth, G.; Mallareddy, J. R.; Tóth, F.; Lipkowski, A. W.; Tourwé, D. RadiotracersTritium Labelled Neuropeptides. $4^{\text {th }}$ European Conference on Chemistry for Life Sciences, Budapest, Hungary. P175 
Tóth, F.; Kleczkowska, P.; Lipkowski, A. W.; Mallareddy, J. R.; Tóth, G.; Tomboly, Cs.; Bojnik, E.; Borsodi, A.; Benyhe, S. Synthesis and Binding Characteristics of a Neurotensin-like Peptide: $\left[{ }^{3} H\right]$ Neuromedin $N$. International Society for Neurochemistry, Athens, Greece. (2011) 